\title{
Late Miocene Extension in Coastal Sonora, México: Implications for the Evolution of Dextral Shear in the Proto-Gulf of California Oblique Rift
}

\author{
AUTHORS: Darin, M.H. ${ }^{1,2}$, Bennett, S.E.K. ${ }^{3}{ }^{*}$, Dorsey, R.J. ${ }^{1}$, Oskin, M.E. ${ }^{3}$, and Iriondo, A. ${ }^{4,5}$ \\ 1 - Department of Geological Sciences, University of Oregon, 1272 University of Oregon, \\ Eugene, Oregon 97403-1272, USA \\ 2 - School of Earth Sciences and Environmental Sustainability, Northern Arizona University, \\ 625 South Knoles Drive, Flagstaff, AZ 86011-4099, USA \\ 3 - Department of Earth and Planetary Sciences, University of California-Davis, 2119 Earth and \\ Physical Sciences, One Shields Avenue, Davis, California 95616, USA \\ 4 - Centro de Geociencias, Universidad Nacional Autónoma de México, Campus Juriquilla, C.P. \\ 76230 Juriquilla, Querétaro, México \\ 5 - The University of Texas at Austin, Jackson School of Geosciences, 2305 Speedway, Stop \\ C1160, Austin, Texas 78712, USA \\ * Current address: U.S. Geological Survey, Department of Earth and Space Sciences, University \\ of Washington, Box 351310, Seattle, Washington 98195, USA.
}

\section{INTRODUCTION}

The transition from distributed extension to localized rifting (e.g., Buck, 1991) and onset of seafloor spreading is a critical step in the process of continental breakup. Modern rifts that preserve an exposed record of rift-related deformation offer valuable insights into the structural evolution of rifted margins and the processes that lead to continental rupture. The Gulf of California (Fig. 1) is a young proto-oceanic oblique rift basin that opened rapidly during late Cenozoic transtension along the Pacific-North America plate boundary (Umhoefer, 2011). This region offers a unique opportunity to explore the kinematics of lithospheric rupture and the structural evolution of a well-exposed obliquely rifted continental margin. While much of the geologic record in the Gulf of California region is accessible and well-studied (e.g., Hausback, 1984; Stock \& Hodges, 1989; Lonsdale, 1989; Gans, 1997; Atwater \& Stock, 1998; Oskin and Stock, 2003a,b; Fletcher et al., 2007; Lizarralde et al., 2007), the timing, kinematics and 
processes responsible for the rapid transition from subduction to rifting, continental rupture and seafloor spreading remain incompletely documented.

The Gulf Extensional Province (GEP) is a broad region of continental extension that extends from eastern Baja California to interior México (Fig. 1; Stock and Hodges, 1989) and is thought to be related to the Gulf of California rift. Major extension in the GEP initiated during latest middle Miocene time following the cessation of subduction west of Baja California, which ended at ca. 12.3 Ma west of southern Baja California and slightly earlier farther north (Spencer \& Normark, 1979; Mammerickx \& Klitgord, 1982; Stock \& Hodges, 1989; Stock and Lee, 1994; Atwater \& Stock, 1998; Fletcher et al., 2007). Extension in the GEP was spatially and temporally isolated from late Oligocene to early Miocene extension in the Southern Basin and Range province (Henry, 1989; Nourse et al., 1994; Lee et al., 1996; Gans, 1997; Henry \& ArandaGomez, 2000; González-León et al., 2010). Latest Miocene localization of plate boundary strain led to marine incursion into the northern Gulf of California at ca. 6.3 Ma and established the modern phase of oblique spreading (Oskin and Stock, 2003a, b; Bennett et al., 2015). The time period between $\sim 12.5$ and $6 \mathrm{Ma}$, and the region that eventually became the modern Gulf of California, are collectively referred to as the "proto-Gulf of California" (e.g., Karig \& Jensky, 1972; Stock \& Hodges, 1989). Contrasting kinematic models have been proposed for the timing, style and distribution of proto-Gulf deformation in northwestern México (e.g., Stock and Hodges, 1989; Fletcher et al., 2007), but they do not directly address the structural processes responsible for plate boundary strain localization, which is required for successful rupture of continental lithosphere.

Field studies (e.g., Umhoefer and Stone, 1996; Aragón-Arreola et al., 2005; Bennett et al., 2013a) and experimental modeling (Withjack and Jamison, 1986; Tron and Brun, 1991; 
Agostini et al., 2009; Brune et al., 2012; Heine and Brune, 2014) show that strike-slip faults are more effective at localizing strain in the upper crust than normal faults because isostatic buoyancy forces related to tectonic unloading are not generated by lateral displacement on steep to vertical strike-slip faults (e.g., Wernicke and Axen, 1988; Buck, 1991; Zoback, 1991; Buck et al. 1999; Brune et al., 2012). Thus the strike-slip component of transtension is mechanically favored to localize strain in highly oblique rift settings such as the Gulf of California. A valid test of this hypothesis for the Gulf of California requires detailed knowledge of the kinematics, distribution, timing and rates of deformation immediately preceding plate boundary localization. Evidence of late Miocene dextral shear along the margins of the proto-Gulf of California (Gans, 1997; Seiler et al., 2010; Herman, 2013; Bennett et al., 2013a; Bennett et al., this volume) highlights the need for data from proto-Gulf age structures to assess the role that strike-slip faults may have played in continental breakup and formation of the Gulf of California.

This paper presents the results of new geologic mapping, fault kinematic analysis, geochronology, and paleomagnetic analysis of middle to late Miocene rocks in the Sierra Bacha ${ }^{1}$ of coastal Sonora, México, along the eastern rifted margin of the northern Gulf of California (Fig. 1). The study area is strategically located immediately northeast of the Coastal Sonora fault zone, a major NW-striking dextral fault zone that experienced transtensional faulting and block rotations between $\sim 8-7$ and 6-5 Ma (Bennett et al., 2013a). Well exposed, proto-Gulf age (ca. 12.5-6 Ma) and older volcanic and sedimentary rocks in the Sierra Bacha allow us to investigate the transition from subduction to oblique rifting in northwestern México. We characterize the timing, distribution, and kinematics of late Miocene deformation in the Sierra Bacha, compare its

\footnotetext{
${ }^{1}$ On most topographic maps of this region, the name "Sierra Bacha" refers only to the coastal range in the northwestern study area, and in some cases the name "Sierra Tordilla" is used interchangeably. For the purpose of this study, all references to the "Sierra Bacha" herein refer to the coastal range and adjacent inland areas to the east and southeast.
} 
structural evolution to that of the adjacent late Miocene Coastal Sonora fault zone, and assess the role of dextral shear in localizing plate boundary strain and facilitating continental rupture in the northern Gulf of California.

\section{REGIONAL TECTONIC EVOLUTION}

Numerous onshore geological and offshore geophysical studies document a tectonic evolution of northwestern México that can be divided into three distinct phases. The first phase involved subduction of the Farallon plate beneath North America and attendant calc-alkaline arc magmatism prior to ca. 12.5 Ma (e.g., Gastil et al., 1979; Hausback, 1984; Lonsdale, 1989; Sawlan, 1991; Vidal-Solano et al., 2005, 2008). While extension prior to 12.5 Ma has been documented in parts of interior Sonora and southern California (Nourse et al., 1994; Lee et al., 1996; Gans, 1997; Henry \& Aranda-Gomez, 2000; Wong and Gans, 2003; González-León et al., 2010), most of the region surrounding the future Gulf of California did not undergo significant extension during subduction (Hausback, 1984; Lee et al., 1996; Nagy, 2000).

The second, "proto-Gulf" phase ( 12.5-6 Ma) began with a major plate boundary reorganization following the cessation of subduction along most of the length of Baja California. Southeastward migration of the Rivera Triple Junction and step-wise abandonment of microplates (e.g., Guadalupe and Magdalena microplates) west of Baja California resulted in incipient coupling between the Pacific and North American plates (Fig. 1; Atwater 1970; Spencer and Normark, 1979; Mammerickx and Klitgord, 1982; Hausback, 1984; Stock and Hodges 1989; Lonsdale, 1991; Atwater and Stock, 1998). Initial Pacific-North America relative plate motion was moderately oblique to the plate boundary (Atwater and Stock, 1998). Dextral transtension was broadly accommodated on structures between the western margin of the Sierra 
Madre Occidental in mainland México (e.g., Gans, 1997) and the waning spreading ridges on the abyssal seafloor west of Baja California (e.g., Michaud et al., 2006), including faulting on the continental shelf (Spencer and Normark, 1979; Fletcher et al., 2007). The distribution and kinematics of that strain is debated. Around $\sim 8 \mathrm{Ma}$, the azimuth of relative plate motion rotated clockwise and by $\sim 6 \mathrm{Ma}$ had rotated by $\sim 12^{\circ}$ at the latitude of the Sierra Bacha, resulting in a higher degree of rift obliquity (Atwater and Stock, 1998, 2013). By the end of the proto-Gulf phase, at least $~ 90 \%$ of Pacific-North America relative motion had become localized into the Gulf of California shear zone (Oskin et al., 2001; Oskin and Stock, 2003b; Bennett and Oskin, 2014), a narrow zone of focused transtensional strain and enhanced crustal thinning and subsidence that hosted marine incursion into the northern Gulf region at ca. 6.3 Ma (McDougall et al., 1999; Oskin and Stock, 2003a; Dorsey et al., 2007, 2011; Bennett et al., 2015).

The third, modern phase ( $\sim 6-0 \mathrm{Ma})$ involves oblique transtension accommodated primarily within the Gulf of California (Fig. 1; Oskin et al., 2001; Oskin and Stock, 2003a,b; Aragón-Arreola and Martín-Barajas, 2007; Lizarralde et al., 2007; Martín-Barajas et al., 2013). Similar to the proto-Gulf phase, a portion of post-6 Ma relative plate motion has been accommodated on transtensional structures in the continental shelf west of Baja California (e.g., Spencer and Normark, 1979; Michaud et al., 2004). Indeed, geodetic studies confirm as much as $\sim 10 \%$ of modern-day relative plate motion still occurs west of Baja California (Plattner et al., 2007). Correlation of various distinctive offset geologic markers demonstrates at $\sim 300 \mathrm{~km}$ of total dextral separation between Baja California and mainland México during Neogene time (Gastil et al., 1973; Abbott and Smith, 1989). Offset correlative ignimbrites in northeastern Baja California, Isla Tiburón and coastal Sonora show that $\sim 250 \mathrm{~km}$ of this $>300 \mathrm{~km}$ total occurred within the Gulf of California marine basin since ca. 6.1 Ma (Oskin et al., 2001; Oskin and Stock, 
2003b). The axes of initial rift segments were established in early pull-apart basins now located along the eastern margin of the Gulf near the modern Sonoran coastline, and this locus of extension jumped westward ca. 3.3-2.0 Ma to its present location in the western Gulf of California (Stock et al., 1991; Oskin and Stock, 2003a; González-Fernández et al., 2005; Aragón-Arreola and Martín-Barajas, 2007). The modern plate boundary is a highly oblique rift with short spreading centers linked by long NW-striking, right-stepping dextral transform faults that are kinematically connected to the southern San Andreas fault system to the north (Fig. 1; Fenby and Gastil, 1991; DeMets and Dixon, 1999).

\subsection{Kinematic Models for Proto-Gulf (ca. 12.5-6 Ma) Dextral Shear}

The global plate circuit model of Atwater and Stock (1998) estimates $\sim 650 \mathrm{~km}$ of PacificNorth America relative plate motion since $\sim 12.5$ Ma. Two end-member kinematic models have been proposed to describe how and where this relative plate motion has been accommodated in northwestern México (Figs. 2A-B). Both models agree that post-6 Ma strain has involved $~ 300$ $\mathrm{km}$ of dextral oblique plate motion, primarily related to localized transtensional rifting in the modern Gulf of California (Gastil et al., 1973; Abbott and Smith, 1989; Oskin et al., 2001; Oskin and Stock, 2003b). However, these end-member models have contrasting implications about how and where the remaining $\sim 300-350 \mathrm{~km}$ of $\mathrm{NW}$-oriented relative plate motion (required to satisfy the plate circuit) was distributed both east and west of the Baja California microplate during the proto-Gulf phase (ca. 12.5-6 Ma).

The strain partitioning model (Fig. 2A) proposes that proto-Gulf strain was partitioned into $\sim 300-350 \mathrm{~km}$ of NW-oriented dextral shear on offshore transform faults west of Baja California and orthogonal NE-SW extension and no dextral shear onshore in the GEP (Spencer \& Normark, 1979; Hausback, 1984; Lonsdale, 1989; Stock \& Hodges, 1989). In contrast, the 
distributed transtension model (Fig. 2B) proposes that proto-Gulf strain involved a maximum of only $150 \mathrm{~km}$ of dextral shear west of the Baja California microplate (Fletcher et al., 2007), which is compatible with an independent estimate of up to $150-170 \mathrm{~km}$ since $\sim 12.5$ Ma based on a tectonic reconstruction of volcanic centers and inferred slab windows in southern California (Wilson et al., 2005). This result implies that the remaining 150-200 km of NW-oriented relative plate motion was accommodated by dextral transtension east of the Baja California microplate in the GEP between 12.5 and 6 Ma (e.g., Gans, 1997; Fletcher et al., 2007; Seiler et al., 2010; Herman, 2013).

The distributed transtension model also implies that $450-500 \mathrm{~km}$ of cumulative NWoriented dextral shear of has been accommodated in the GEP since $~ 12.5 \mathrm{Ma}$. However, recent interpretation of offshore seismic data across the Alarcón Rise suggests only 400 km of cumulative NW-directed transtensional opening in the southern Gulf of California since 12.5 Ma (Sutherland et al., 2012). Subtracting $~ 300 \mathrm{~km}$ of post-6 Ma transtensional opening in the Gulf of California leaves a residual of only $100 \mathrm{~km}$ of dextral shear in the GEP during the proto-Gulf phase, which must have been accommodated onshore in the region surrounding the modern Gulf of California. In summary, plate circuit constraints and available offshore geologic data suggest that the GEP accommodated a maximum of 100-200 km of NW-oriented dextral shear between $\sim 12.5$ and $6 \mathrm{Ma}$.

\subsection{Onshore Evidence of Proto-Gulf Dextral Shear}

Scattered evidence of proto-Gulf age dextral shear is documented onshore in the northern GEP (e.g., Gans, 1997; Lewis \& Stock, 1998; Nourse et al., 2005; Seiler et al., 2010, 2011; Bennett et al., 2013a; Herman, 2013; Vidal-Solano et al., 2013; García-Martínez et al., 2014; Bennett et al., this volume), but the timing, total magnitude, and spatial extent of dextral strain 
are not fully documented. For example, Bennett et al. (2013a) documented a minimum of $41 \pm$ $11 \mathrm{~km}$ of dextral shear in the Coastal Sonora fault zone (CSFZ) near Bahía de Kino, most of which likely accumulated during latest proto-Gulf time ca. 7-6 Ma (Fig. 3). A paleomagnetic transect across the Pacific-North America plate boundary led Bennett and Oskin (2014) to propose the existence of the Gulf of California shear zone, a narrow ( $100 \mathrm{~km}$-wide) belt of dextral shear and large-magnitude clockwise vertical-axis block rotation that initiated during latest Miocene time and kinematically linked to the proto-San Andreas fault system and eastern California shear zone to the north. The CSFZ is a local component of the Gulf of California shear zone, and represents a first-order plate-boundary feature. Notably, no prior study has documented direct evidence for major dextral shear zones structurally inboard (northeast) of the Gulf of California shear zone.

Evidence of proto-Gulf age dextral shear in the northern GEP contradicts the strict strain partitioning end-member model. Similarly, less than half of the dextral shear predicted by the distributed transtension model (at least 150-200 km) in the GEP during proto-Gulf time has not been documented. Thus, some intermediate or hybrid model may better explain the kinematic evolution of the proto-Gulf of California (e.g., Fig. 2C; see section 7.3).

\section{METHODS}

\subsection{Geologic Mapping}

In this study we used detailed geologic mapping and structural analysis to build on the pioneering work of regional (1:150,000-scale) geologic maps (Gastil and Krummenacher, 1976, 1977) and to investigate the timing and kinematics of proto-Gulf deformation in coastal Sonora. Detailed geologic and structural mapping (Fig. 4) was conducted at scales of 1:10,000 and 
1:30,000 using SPOT Image multispectral 2.5-meter resolution imagery from Google Earth Pro, overlain by a UTM grid. Topographic base maps include the 'Desemboque' and 'Arivaipa' 1:50,000-scale Carta Topografica base maps produced by the Comision de Estudios del Territorio Nacional, México.

\subsection{Geochronology}

We analyzed samples of volcanic units to provide age constraints for stratigraphic groups of rocks in the Sierra Bacha (Fig. 5; Table 1). Three different labs were used for geochronology analyses. ${ }^{40} \mathrm{Ar} /{ }^{39} \mathrm{Ar}$ total fusion and step-heating analyses were performed at the U.S. Geologic Survey Thermochronology Laboratory and at the Oregon State University Argon Geochronology Laboratory. U-Pb analyses were performed at the Isotopic Studies Laboratory (LEI) at the Universidad Nacional Autónoma de México (UNAM). Errors for all new geochronologic ages are reported at the $2-\sigma$ uncertainty level. U-Pb and ${ }^{40} \mathrm{Ar} /{ }^{39} \mathrm{Ar}$ analytical data are presented in Supplemental Tables S1-S3. Specific details regarding the geochronology methods and analytical procedures can be found in Appendix A.

\subsection{Geochemistry}

Ten samples from the Sierra Bacha were analyzed for whole-rock geochemistry (Table 2) in the X-Ray Fluorescence (XRF) Lab at Michigan State University. For all ignimbrite samples, analyses were performed on inclusion-free, devitrified matrix from densely welded facies. All geochemical analyses were performed using a Bruker S4 PIONEER $4 \mathrm{~kW}$ wavelength dispersive X-ray fluorescence spectrometer. Bulk rock analysis involved high-temperature fusion of powdered samples into homogenous glass disks by dilution with a lithium-tetraborate flux. Each sample was analyzed for major elements, and the trace elements $\mathrm{Rb}, \mathrm{Sr}$, and $\mathrm{Zr}$. Data reduction was performed with SPECTRAplus software using fundamental parameters. 


\subsection{Fault Kinematic Analysis}

Brittle fault kinematic indicators in the Sierra Bacha were measured from mostly minor fault surfaces, as most major faults are not well exposed. Fault slip data $(n=41$; Supplemental Table S4) include fault orientation, rake of kinematic indicator, sense of shear, and confidence in the quality of the shear sense indicator (e.g., high, moderate, low, very low). Kinematic indicators included striated grooves (slickenlines), Riedel shears, smears, and steps (Petit, 1987; Angelier, 1994; Doblas, 1998). Fault kinematic indicators in which a reliable sense of shear was not observed ( $\mathrm{n}=7)$ were given a confidence rank of "very low" and assigned a shear sense based on the rake of the kinematic indicator and the assumption that it formed under a dominantly extensional (rather than contractional) stress regime. Fault kinematic analysis was conducted using the graphical kinematic method of Marrett and Allmendinger (1990) to calculate the average orientations of the principal contraction $(\mathrm{P})$ and extension $(\mathrm{T})$ axes for each fault slip datum and convert them into a pseudo-fault plane solution. Because we were unable to determine displacement, gouge thickness, and fault trace length for most faults where fault slip data were collected, we calculate an unweighted moment tensor summation by computing Bingham statistics on the linked P- and T-axis distributions (Marrett and Allmendinger, 1990). Thus we were able to determine the orientations of the principal contraction and extension axes, but not the absolute magnitude of strain. Structural and fault kinematic analyses were conducted using FaultKin v. 7.2.9 and Stereonet v. 9.3 (Marrett and Allmendinger, 1990; Allmendinger et al., 2012; Cardozo and Allmendinger, 2013).

\subsection{Paleomagnetic Analysis}

A total of 61 randomly oriented core samples were collected from five paleomagnetic drill sites in the Sierra Bacha. Between 6 and 19 cores were extracted from each site using a 
portable gasoline-powered drill with a 1-inch diameter water-cooled diamond bit. Each core was oriented in the field with both a magnetic compass and a sun compass to an accuracy of $\pm 1^{\circ}$. Samples were typically collected from an area of $20-800 \mathrm{~m}^{2}$ at each site to avoid local heterogeneities and to allow within-site homogeneity of remnant magnetization to be evaluated. In the laboratory, specimens were cut to a height of $1 \mathrm{~cm}$ and subjected to alternating-field (AF) demagnetization experiments. All experiments were performed at the California Institute of Technology Paleomagnetics Laboratory in a Model 581 2-G SQUID (Superconducting Quantum Interference Device) rock magnetometer, housed in a magnetically shielded $\mu$-metal room with an ambient magnetic field less than $10 \mathrm{nT}$. Natural remanent magnetization (NRM) was measured for each of the specimens, followed by two identical low-temperature (LT) steps in which each specimen was cooled to $77 \mathrm{~K}$ in liquid nitrogen $\left(\mathrm{N}_{2}\right)$ and allowed to warm to room temperature. Magnetization was measured after each cooling-warming cycle. No other thermal demagnetization steps were performed. All 61 specimens were then subjected to a total of $13 \mathrm{AF}$ demagnetization steps from $2.5-10 \mathrm{mT}$ in increments of $2.5 \mathrm{mT}$, followed by high-AF demagnetization from 10-30 $\mathrm{mT}$ in increments of $5 \mathrm{mT}$, and 30-80 $\mathrm{mT}$ in increments of $10 \mathrm{mT}$.

Raw paleomagnetic data (Table 3), including Fischer and Bingham statistics, were obtained using Paleomagnetic Magnetometer Control System, 2010, v 2.4.0 (Kirschvink et al., 2008). All data were analyzed in PaleoMag v $3.1 b 2$ (Jones, 2002) using the principal component analysis of Kirschvink (1980) for calculating the best fit for a linear vector of magnetic remanence for several user-selected demagnetization steps for each specimen.

\section{STRATIGRAPHY}


Geologic mapping, lithologic and petrographic analysis, ${ }^{40} \mathrm{Ar} /{ }^{39} \mathrm{Ar}$ and $\mathrm{U}-\mathrm{Pb}$ geochronology, whole-rock (XRF) geochemistry, and clast counts reveal 33 distinctive Neogene lithologic units in the Sierra Bacha study area (Darin and Dorsey, 2014). Basement units include crystalline igneous rocks of the late Cretaceous coastal Sonora batholith, as well as associated Mesozoic-Paleozoic(?) metamorphic protoliths (Gastil and Krummenacher, 1976, 1977; RamosVelázquez et al., 2008). The Neogene section overlying a basement nonconformity represents the voluminous extrusion of predominantly intermediate lava flows and domes, basalt, rhyolite, welded tuff, and subordinate volcaniclastic nonmarine sedimentary rocks with a maximum composite thickness of $\sim 2.4 \mathrm{~km}$. A summary of all geochronologic ages from the Sierra Bacha are listed in Table 1.

In this study, lithologic units overlying basement rocks are divided into four informal groups (Figs. 4, 5) based on an established regional stratigraphic framework for coastal Sonora (Stock, 1989; Oskin \& Stock, 2003c). A more detailed, 1:30,000-scale geologic map of the Sierra Bacha contains comprehensive descriptions of all lithologic units in the study area (Darin and Dorsey, 2014). In the following sections, we describe the salient details of each stratigraphic group and several key geologic units therein.

\subsection{Pre-Cenozoic Basement}

Pre-Cenozoic basement in the Sierra Bacha consists of Paleozoic(?) to Mesozoic metamorphic rocks and late Cretaceous igneous intrusions of the coastal Sonora batholith (Anderson and Silver, 1969; Gastil et al., 1974; Gastil and Krummenacher, 1977; Gastil, 1993; Ramos-Velázquez et al., 2008). Metamorphic units include mostly low-grade, hornfels-facies metasedimentary rocks with abundant primary quartz and secondary muscovite, along with minor metavolcanic rocks, metacarbonate, and quartzite. Crystalline basement units consist 
primarily of medium- to coarse-grained tonalite and granodiorite with subordinate granite. Crosscutting relationships and the presence of tonalite xenoliths within the granite indicate that virtually all granite intrusions postdate the emplacement of tonalite. U-Pb zircon ages of granitic intrusions in the coastal Sonoran batholith range from ca. 90-69 Ma (Ramos-Velázquez et al., 2008). Ramos-Velázquez et al. (2008) report an age of $69.4 \pm 1.2 \mathrm{Ma}$ [U-Pb] for the Tepopa tonalite located $15 \mathrm{~km}$ south of the Sierra Bacha. A similar age of $71.7 \pm 1.4 \mathrm{Ma}[\mathrm{K}-\mathrm{Ar}]$ was reported by Gastil and Krummenacher (1977) for a granodiorite located $4 \mathrm{~km}$ northwest of the study area near Las Cuevitas (Fig. 3).

The geometry of the nonconformable contact between pre-Cenozoic basement rocks and the overlying strata varies from subplanar in the Sierra Tordilla, to a shallow buttress unconformity in the western Cerro Colorado where predominantly Neogene rocks onlap the basement at typically shallow $\left(<10^{\circ}\right)$ angles, except for one locality where the onlap angle approaches $\sim 40^{\circ}$ (Fig. 4, between Noriega and Pozo Coyote faults). These relationships indicate that late Cretaceous intrusions were exhumed by early Miocene time, when low to moderate paleotopography with up to $400 \mathrm{~m}$ of relief existed in the Sierra Bacha. This locally significant paleo-relief introduces some uncertainty to structural interpretations in this area.

\subsection{Group 1: Basal Sedimentary Rocks}

Stratigraphic group 1 consists of nonmarine sedimentary rocks that overlie igneous and metamorphic basement, representing some of the oldest Cenozoic deposits in northwestern México (Gastil et al., 1975; Stock, 1989; Dorsey and Burns, 1994; Oskin and Stock, 2003c). The only unit in the study area that belongs to group 1 is a distinctive fluvial conglomerate (Tcf), which is only exposed in the southernmost map area (Fig. 4). Tcf is up to $250 \mathrm{~m}$-thick and consists of mostly clast-supported pebble-cobble conglomerate with rare boulders up to $60 \mathrm{~cm}$ in 
diameter in a red granular matrix. Clasts are well- to very well-rounded and include quartzite, tonalite, chert, limestone, and various metamorphic and volcanic lithologies. We correlate this unit in the Sierra Bacha with an exotic-clast conglomerate located $9 \mathrm{~km}$ along strike to the southeast in the Sierra Seri (Fig. 3; Gastil et al., 1973) based on the presence of limestone clasts containing possible fusulinid and gastropod fossils, a similar extra-regional clast assemblage, and its proximity to previously mapped outcrops. Despite some notable differences in lithology, textural maturity and stratigraphic thickness, we tentatively correlate this unit in the Sierra Bacha with similar strata in northern Baja California including the Mesa Formation (Dorsey and Burns, 1994) and group 1 strata in the Santa Rosa Basin (Seiler et al., 2013).

The age of $T c f$ is reasonably constrained by geologic and stratigraphic data from Baja California and coastal Sonora. The oldest unit consistently overlying group 1 strata in Baja California is the ca.12.6 Ma Tuff of San Felipe (Stock et al., 1999). Elsewhere in Baja California, upper group 1 strata are overlain by, or intercalated with, volcanic rocks as old as ca. 20-21 Ma (Gastil et al., 1979; Lewis, 1996; Stock, 1989; Seiler et al., 2013). In the Sierra Bacha, group 1 strata are overlain by and structurally concordant with late middle Miocene volcanic and volcaniclastic rocks (Figs. 4, 5). These data, along with additional stratigraphic constraints in Baja California (e.g., Stock, 1989; Dorsey \& Burns, 1994; Oskin and Stock, 2003c; Seiler et al., 2013) suggest an Oligocene to middle Miocene age for group 1 strata in the Sierra Bacha.

\subsection{Group 2: Middle Miocene Volcanic and Sedimentary Rocks (ca. 15-12.5 Ma)}

Stratigraphic group 2 consists of basaltic to rhyolitic lava flows and interbedded pyroclastic rocks that were emplaced during Miocene subduction and arc volcanism (Gastil et al., 1979; Sawlan, 1991). Group 2 units are up to 1100 m-thick at Cerro Las Burras and are best exposed at Cerro Colorado and in the coastal Sierra Tordilla where they have an average 
composite thickness of 500-800 m (Fig. 4). Basal units nonconformably overlie crystalline and metamorphic basement and in some areas unconformably overlie thin deposits of group 1 strata. Calc-alkaline to alkaline volcanic units consist of peraluminous basaltic-trachyandesite, trachyandesite, and dacite flows (Table 2; Fig. 6).

A 10-40 m-thick, yellow to red, crystal- and lithic-rich rhyolite tuff, here named the Tuff of Cerro Colorado (Ttc), is an important stratigraphic marker at Cerro Colorado (Darin and Dorsey, 2014). The base of Ttc contains a 2-8 $\mathrm{m}$ thick, yellow to orange, nonwelded zone with yellow, red, and purple tephra and subangular volcanic lithic fragments that grades upward into a brick-red, partially-welded crystal-lithic tuff with up to 5\% yellow and gray pumice and up to $10 \%$ phenocrysts (quartz > feldspar). Zircons separated from a sample of Ttc yield a U-Pb age of $14.20 \pm 1.60 \mathrm{Ma}$ (Fig. 7A; Table 1).

Group 2 units in the western portion of the study area are distinctly different from those in the east and are dominated by a proximal to medial stratovolcano facies consisting of dacite lava flows (Tdf) and mono-lithologic tuffs and breccias $(T d t)$. Although the absolute ages of these units are not constrained by geochronology, they are inferred to be coeval with other group 2 units to the east and southeast based on several correlable units that occur in the central and northern map area (Fig. 5). For example, $5 \mathrm{~km}$ northeast of El Desemboque, the ca. 12.6 Ma Tuff of San Felipe (Ttsf; Stock et al., 1999; Oskin and Stock, 2003b) conformably overlies dacite tuffs and breccias of group 2 (UTM: 12R, $367090 \mathrm{E}, 3269620 \mathrm{~N}$ ) that are commonly found in the Sierra Tordilla in the western portion of the study area (Darin and Dorsey, 2014).

Compositionally similar group 2 units in Baja California have ages ranging from 15.5 to $16.7 \mathrm{Ma}$ (e.g., the "Tombstone Dacite" of Nagy et al., 1999).

\subsubsection{Tuff of San Felipe (Ttsf)}


The Tuff of San Felipe (Ttsf), one of the youngest units in stratigraphic group 2, is a welldocumented regionally extensive rhyolite ignimbrite that serves as an important geologic marker for tectonic reconstructions of the northern Gulf of California (e.g., Stock et al., 1999; Oskin et al., 2001; Oskin and Stock, 2003b; Bennett and Oskin, 2014). Stock et al. (1999) determined that an age of $\sim 12.6$ Ma for Tts $f$ was most consistent with available geologic and geochronologic constraints in northeastern Baja California. This age is very similar to an age of $12.50 \pm 0.08 \mathrm{Ma}$ $\left[{ }^{40} \mathrm{Ar} /{ }^{39} \mathrm{Ar}\right]$ for Ttsf in coastal Sonora (Bennett et al., 2013a). Vent-proximal facies are found $\sim 10$ km east of the Sierra San Felipe in northeastern Baja California (Stock et al., 1999), 3 km east of Punta Chueca in coastal Sonora (Fig. 3; Oskin and Stock, 2003b), and potentially in the Sierra Libre $\sim 70 \mathrm{~km}$ north of Guaymas (Vidal-Solano et al., 2013). The Ttsf ignimbrite deposit is estimated to cover over $4,000 \mathrm{~km}^{2}$ on both margins of the northern Gulf of California (Oskin and Stock, 2003b).

In the Sierra Bacha, the Tuff of San Felipe is a burgundy to orange, densely welded tuff containing abundant yellow to white pumice and $10-15 \%$ anorthoclase phenocrysts, rare zoned pyroxene, and no observed phenocrystic quartz. In addition to abundant anorthoclase, common diagnostic features in both the Sierra Bacha and in northeastern Baja California include trachyterhyolite inclusions containing abundant alkali feldspar in a dark, glassy groundmass, and abundant flattened pumice fiamme up to $25 \mathrm{~cm}$-long, which form a well-defined eutaxitic foliation in more densely welded facies (Fig. 8A; cf. Stock et al., 1999). Approximately 5 km northeast of El Desemboque (Fig. 4), Ttsf is 25-70 m-thick with a thin ( $<1 \mathrm{~m}$-thick), laterally discontinuous, black basal vitrophyre. The lower densely welded and fiamme-rich member (20$40 \mathrm{~m}$-thick) grades upward into a 5-30 m-thick non-welded zone with intact, undeformed pumice. On the northeastern flank of Cerro Pelón, Ttsf is only 30 m-thick with a similarly 
welded base (20 m-thick) grading upward into a non-welded, spherulitic zone (10 m-thick); the limited areal extent and map pattern in this area suggest that this may be a paleo-valley deposit (Fig. 4; Darin and Dorsey, 2014).

\subsubsection{Tuff of San Ignacio (Ttsi)}

The youngest unit belonging to group 2 is the Tuff of San Ignacio (Ttsi), a pink-whiteorange, densely welded, spherulitic rhyolite ignimbrite with an average thickness of 20-40 m (Darin and Dorsey, 2014; Figs. 4, 8B). Zircon grains separated from a sample of Ttsi yield a mean $\mathrm{U}-\mathrm{Pb}$ age of $12.57 \pm 0.10 \mathrm{Ma}$ (Fig. 7B; Table 1). The three youngest grains have elevated uranium concentrations that suggest variable degrees of lead loss. We interpret that the seven youngest zircons may represent a trend of lead loss and have omitted them from the mean age calculation (Supplemental Table S1). We also determine a ${ }^{40} \mathrm{Ar} /{ }^{39} \mathrm{Ar}$ sanidine total fusion age of $12.63 \pm 0.03 \mathrm{Ma}$ for Ttsi at Lomas Ona-Jeco (Fig. 9A) from the same location where Gastil and Krummenacher (1977) determined a K-Ar age of 10.4 \pm 0.2 Ma for this tuff (Table 1; Fig. 4).

Ttsi contains unique subrounded to angular, plagioclase-phyric, vesicular andesite lithic fragments up to $5 \mathrm{~cm}$ in diameter (average $\sim 1 \mathrm{~cm}$ ) and uncommon centimeter-scale white to pink fiamme (Fig. 8C); locally abundant fiamme up to $12 \mathrm{~cm}$-long are observed at Lomas Ona-Jeco and Cerro Colorado (Fig. 4). While quartz and biotite phenocrysts are uncommon in hand samples, petrographic analysis reveals very rare small pumice fragments, and partially dissolved alkali feldspar, quartz, and biotite in an ash-rich groundmass. Ttsi commonly consists of a $0.5-1$ m-thick, black-brown basal vitrophyre with rare feldspar micro-phenocrysts, overlain by a 5-8 m-thick salmon-orange, crystal- and lithic-rich densely welded zone with 1-10\% modal abundance of phenocrysts (quartz $>$ alkali feldspar $>$ biotite). The welded zone grades upward into a 10-30-m-thick, pink-white, partially welded zone of vapor-phase alteration characterized 
by a spherultic texture and abundant $0.5-3.0 \mathrm{~cm}$-diameter quartz-filled spherules and lithophysae that decrease in abundance up-section. Internal rheomorphic flow deformation in the form of severely folded and recrystallized pumice fiamme (Fig. 8D) is characteristic of Ttsi at Cerro Las Burras where it reaches a maximum thickness of $\sim 300 \mathrm{~m}$. Eutaxitic foliation is densely-spaced $(<$ $1 \mathrm{~cm}$ ) and rheomorphism is irregularly distributed with pumice fiamme showing varying degrees of deformation, some of which are flattened and stretched up to $40 \mathrm{~cm}$ long (1:80 aspect ratio).

\subsubsection{Similarities and Distinctions Between Ttsi and Ttsf}

Ttsi and Ttsf have statistically indistinguishable isotopic ages of $\sim 12.6-12.5 \mathrm{Ma}$, a similar and unique paleomagnetic remanence direction (Stock et al., 1999; Bennett et al., 2013a; this study), broadly similar geochemical characteristics, and both contain similarly distinct dark volcanic inclusions. Major and trace element data from Ttsf in the Sierra Bacha correspond well with a compilation of published data for Ttsf elsewhere in Sonora and northern Baja California (Fig. 6B; Stock et al., 1999; Vidal-Solano et al., 2005, 2008). The two samples of Ttsi show distinct variations in $\mathrm{Rb}$ and $\mathrm{Zr}$ concentrations (Fig. 6B), possibly due to chemical zoning within the thicker rheomorphic Ttsi at Cerro Las Burras (sample SON10-83A, Table 2; Fig. 4). Both Ttsi samples plot just outside of the published ranges of Ttsf in both major and trace element concentrations (Fig. 6), although these differences appear to be insignificant for $\mathrm{Zr}$ and $\mathrm{Sr}$. Thus, the subtle geochemical variations make it difficult to interpret the possible genetic relationship between Ttsf and Ttsi based on geochemistry alone. There are, however, some notable petrographic differences between these two units. Although generally uncommon, quartz and biotite are present and locally abundant (up to $10 \%$ modal content) in Ttsi. These crystal phases are not found in Ttsf, except as rare accessory phenocrysts in the Sierra San Fermín (Lewis, 1996), Santa Isabel Wash (Nagy, 1997) in northern Baja California, as well as the Santa Rosa 
Basin where they have been observed near the base of the unit (Bryant, 1986; Stock et al., 1999; Seiler et al., 2013), suggesting a likely xenocrystic origin there.

More importantly, stratigraphic relationships suggest that Ttsi and Ttsf may be different tuffs erupted nearly synchronously at ca. 12.6 Ma. Both tuffs display markedly different exposure and regional thickening patterns. Exposures of Ttsi thicken toward the northeast, from an average thickness of $\sim 40 \mathrm{~m}$ at Lomas Ona-Jeco and Cerro Colorado to a maximum thickness of $\sim 300 \mathrm{~m}$ at Cerro Las Burras, where rheomorphic structures typical of vent-proximal outflow facies are also observed (Fig. 8D). This suggests a probable vent for Ttsi located northeast of the study area. In contrast, the vent for Ttsf is currently located $\sim 60 \mathrm{~km}$ south-southeast of Cerro Pelón along the Sonoran coast (Fig. 3; Oskin and Stock, 2003b), across the large-offset CSFZ (Bennett et al., 2013a; Vidal-Solano et al., 2013). Restoration of $60 \pm 30 \mathrm{~km}$ of dextral slip across the CSFZ, permitted from matching distinctive group 1 conglomerate exposures of Gastil et al. (1973) after restoration of the opening of the northern Gulf of California (Bennett et al., 2013a; Vidal-Solano et al., 2013), places the original Ttsf vent location at least $100 \mathrm{~km}$ southeast of the Sierra Bacha.

Ttsf and Ttsi are not found in depositional contact with each other except in one location in the Cerro Pelón, where Ttsf is found stratigraphically below Ttsi (Fig. 4; UTM: 12R, 371248 E, $3269445 \mathrm{~N})$. The contact between them is poorly exposed and marked by an up-section change from nonwelded spherulitic upper Ttsf to welded Ttsi containing small pink fiamme and abundant (up to $\sim 15 \%$ ) quartz phenocrysts; neither tuff exhibits a basal vitrophyre in this location. Aside from the Cerro Pelón location, the observation that the two tuffs are not found in depositional contact with one another supports that they may have emanated from different directions. If they had indeed erupted from the same vent, one would expect similar distributions 
of the deposits and more common co-occurrence in the field. Rather, the lack of observed stratigraphic contact between Ttsf and Ttsi could be due to limited extent of distal Ttsf deposits that were isolated by paleotopography and/or restricted to paleo-valleys in the Sierra Bacha.

Based on the available geologic evidence, our preferred interpretation is that Ttsi and Ttsf are different lithologic units erupted nearly synchronously at ca. 12.6 Ma from spatially distinct volcanic vents. However, the distribution and vent location of Ttsi and its possible genetic relationship with Ttsf remain incompletely understood. Geochemical and paleomagnetic similarities permit that Ttsi may be a separate cooling unit of Ttsf. For example, multiple Ttsf cooling units have been mapped near Punta Chueca, 65 km south-southeast of Cerro Pelón (Bennett et al., 2013a). However, the stratigraphic relationships across the Sierra Bacha (e.g., thickening patterns) strongly suggest disparate vent locations for Ttsf and Ttsi. Thus, additional work is needed in coastal Sonora (and possibly Baja California) to determine the nature of the relationship between these ignimbrites.

\subsection{Group 3a: Latest Middle Miocene Volcanic Rocks (ca. 12.5-11.7 Ma)}

Rocks of group 3a were deposited after subduction ended and during early plate boundary reorganization in the GEP (Oskin and Stock, 2003b). This sequence lies stratigraphically above the ca. 12.6 Ma group 2 ignimbrites (Ttsf, Ttsi), and has an average composite thickness of 600-1,000 m, reaching a maximum exposed thickness of $1,550 \mathrm{~m}$ at Cerro Prieta. Lithologic units in this group consist predominantly of peraluminous basalt to rhyolite lava flows and subordinate rhyolitic tuffs and locally-derived, thin- to thick-bedded, polymict nonmarine volcaniclastic conglomerate and breccia (Tc2). Group 3a units dip moderately to the northeast and are structurally concordant and conformable with underlying group 2 strata. 
Samples from several lava flow units in group 3 a were analyzed for $\mathrm{U}-\mathrm{Pb}$ and ${ }^{40} \mathrm{Ar} /{ }^{39} \mathrm{Ar}$ geochronology (Table 1). The stratigraphically lowest unit analyzed in group $3 \mathrm{a}$ is $T d 2$, which consists of a $\sim 300 \mathrm{~m}$-thick sequence of purple to gray, aphanitic trachydacite lava domes containing up to $5 \%$ blocky sanidine and plagioclase phenocrysts and a well-defined 1 to $4 \mathrm{~cm}$ spaced eutaxitic (flow) foliation. We determine a mean $\mathrm{U}-\mathrm{Pb}$ age of $13.41 \pm 0.37 \mathrm{Ma}$ from a population of 25 zircons (Fig. 7C). However, this mean age is discordant with its stratigraphic position above the $~ 12.6 \mathrm{Ma}$ Tuff of San Ignacio (Ttsi; Table 1) and below 11.8 Ma lava flows discussed below. The youngest single zircon age analyzed is $11.8 \pm 0.6 \mathrm{Ma}$ (see Supplemental Table S1), which is compatible with stratigraphic and other geochronologic constraints. A younger, stratigraphically constrained age of $\sim 12.6-11.8 \mathrm{Ma}$ for $T d 2$ would imply that nearly all of the zircons analyzed in this sample are inherited (i.e., xenocrystic or accidental) rather than primary, an interpretation consistent with other old ages ( $20 \mathrm{Ma}$ and $\sim 86 \mathrm{Ma}$ ) obtained from this sample (Fig. 7C; Table S1). This suggests that our mean age calculation should be interpreted as a maximum emplacement age for this unit. Regardless, this discordance does not have a significant effect on interpretations of the structural and stratigraphic evolution of the study area.

Ta3 consists of a series of basaltic-andesite lava flows containing $\sim 5 \%$ rare lath-shaped plagioclase phenocrysts in a black aphanitic groundmass. $\mathrm{A}^{40} \mathrm{Ar} /{ }^{39} \mathrm{Ar}$ isochron age of $11.76 \pm$ 0.16 Ma was determined for this unit (Fig. 9B), which is in direct stratigraphic contact above $T d 2$ (Fig. 5). The youngest unit dated in group 3a is $\operatorname{Tr} 2$, which consists of several 60-90 m-thick, gray to purple aphanitic rhyolite lava flows or domes. We determine a ${ }^{40} \mathrm{Ar} /{ }^{39} \mathrm{Ar}$ age of $11.70 \pm$ 0.40 Ma for this unit (Fig. 9C).

\subsection{Group 3b: Late Miocene Conglomerates and Basalts (post-11.7 Ma)}


Rocks of stratigraphic group 3b unconformably overlie group 3a units (Figs. 4, 5) and consist of conglomerates $(T c 3)$ and basalt flows $(T b a)$ that dip gently $\left(<30^{\circ}\right)$ to the northeast (Fig. 10A). Tc3 consists of massive volcaniclastic conglomerate to pebbly sandstone. Although similar in composition to older conglomerate units $(T c 2)$ of group $3 \mathrm{a}, T c 3$ contains a significantly higher percentage of basement clasts (Fig. 11). More importantly, Tc3 displays bedding dips that decrease systematically up-section ("fanning dips") from about $39^{\circ}$ near its base to horizontal in the hanging wall of the Noriega fault in the southern map area (Fig. 12C). A similar fanning-dip relationship is inferred in the hanging wall of the Libertad fault in the northeastern map area (Fig. 12B). A maximum age for $T c 3$ is $\sim 11.7$ Ma based on the youngest dated underlying unit in the Cerro Colorado, but the minimum age for this unit is not well constrained. A $30 \mathrm{~cm}$-thick ash layer was observed interbedded within $T c 3 \sim 20-60 \mathrm{~m}$ up-section from its basal contact, but ${ }^{40} \mathrm{Ar} /{ }^{39} \mathrm{Ar}$ total fusion ages on both biotite and potassium feldspar were dominated by ca. $72-47$ Ma grains (youngest grain age $\sim 22 \mathrm{Ma}$ ) which we interpret as a detrital signal indicating that the ash is actually a reworked volcaniclastic deposit (A. Iriondo, unpublished data).

The Basalt of Arivaipa (Tba) is named here for a sequence of horizontal to shallowlyinclined, 2-15 m-thick basalt flows located in the northern, central, and eastern study area and lies above an angular unconformity with all older units (Fig. 4; Darin \& Dorsey, 2014). Individual flows vary from aphanitic with micro-phenocrysts of plagioclase to porphyritic with small olivine phenocrysts $(<2 \mathrm{~mm}$ and variably altered to iddingsite) and euhedral plagioclase megacrysts up to $10 \mathrm{~mm}$-long. Most flows have a 1-3 m-thick red-black basal flow breccia, vesicular upper and lower contacts, and well-defined $\sim 0.5 \mathrm{~m}$-spaced vertical joints. Gastil and Krummenacher (1977) reported a K-Ar age of 6.4 \pm 1.9 Ma for Tba at Cerro Prieta where it dips 
$\sim 20^{\circ}$ to the northeast (Fig. 4; Table 1). We calculate $\mathrm{a}^{40} \mathrm{Ar} /{ }^{39} \mathrm{Ar}$ laser total fusion age on groundmass of $10.59 \pm 0.06 \mathrm{Ma}$ for the stratigraphically oldest subhorizontal basalt flow within Tba at Cerro Las Burras (Fig. 9D).

\subsection{Group 4: Conglomerates and Alluvium (Late Miocene[?] to Quaternary)}

Group 4 consists of subhorizontal, nonmarine sedimentary units that unconformably overlie all other units in the Sierra Bacha. Alluvial conglomerates $(Q T g)$ are poorly consolidated and consist of pebbly sandstone and clast-supported sandy pebble conglomerate. The clast assemblage is polymict and consists predominantly of volcanic clasts (56\% modal concentration) and relatively less basement clasts (44\% modal concentration) (Fig. 11). We interpret these deposits as locally-derived alluvial fans on the basis of horizontal stratification and a maximum, likely primary, dip $\sim 5^{\circ}$. Although a maximum age for this unit cannot be determined, we interpret these as relatively young, post-tectonic deposits based on the generally poor consolidation and lack of deformation.

\section{STRUCTURAL GEOLOGY}

Miocene and older units in the Sierra Bacha are observed to be cut by normal, sinistral, normal-oblique, and dextral faults (Fig. 4; Darin and Dorsey, 2014). We found no evidence of faulting or tilting of the youngest map units (group 4), which appear to be undeformed with subhorizontal dips $\left(0-5^{\circ}\right)$. From northeast to southwest, major structures consist of the Libertad, Pozo Coyote, Noriega and Bacha faults, a series of NW-SE-striking, SW-dipping normal faults. Movement on these faults has resulted in uniform down-to-the-northeast tilting of intervening fault blocks. Bedding and eutaxitic foliation in groups 2 and 3a units $(\mathrm{n}=196)$ strike NW-SE and have an average dip of $43^{\circ}$ down-to-the-northeast (Fig. 13A). The average strike of measured 
fault surfaces $(\mathrm{n}=65)$ is NW-SE $\left(331^{\circ}\right.$; Fig. 13B), sub-parallel to strike ridges of tilted strata (321 ${ }^{\circ}$; Fig. 13A). The structural framework can be broadly classified as a series of domino-style fault blocks that tilt all group 1,2, and 3a (pre-tectonic) rocks moderately to the northeast $\sim 30$ $60^{\circ}$, forming asymmetric half-grabens that are preserved locally and filled with group $3 \mathrm{~b}$ (syntectonic) units.

Most of the major faults are concealed beneath Quaternary alluvium and not well exposed, leading to substantial uncertainty in their degree of inclination. The locations and attitudes of most large faults are inferred from stratigraphic constraints such as missing or repeated intervals, fault-to-bedding cut-off angles, and structural separation in map view. In structural cross sections (Fig. 12), the orientations of unexposed faults lacking geometric constraints are assumed to be parallel to exposed faults nearby. For major first-order structures in the study area (i.e., Bacha, Libertad, Noriega faults), uncertainties regarding total fault displacement are based on the maximum observed paleo-relief in the study area $(\sim 400 \mathrm{~m})$, which also accounts for the possibility that ignimbrite markers may not have been deposited horizontally. Quantifying dextral slip on structures is important because the relative influence of extension and dextral shear in the GEP is highly debated. Thus, in the following sections we discuss available evidence for strike-slip faulting and estimate its potential at least to the closest order-of-magnitude.

\subsection{Libertad fault}

Gastil and Krummenacher $(1976,1977)$ first identified the onshore Libertad fault as a sub-vertical, down-to-the-west fault that juxtaposes Miocene volcano-sedimentary units with crystalline basement north of the Sierra Bacha. They speculate that the Libertad fault, like other more continuous faults in the area, is probably a strike-slip fault, although they go on to note that 
rock units on opposite sides of the fault are not drastically different along its entire trace (Gastil and Krummenacher, 1977, p. 196). They also hypothesize that the Libertad fault may link to the offshore Amado transform fault in the Gulf of California along strike to the northwest (Fig. 3).

The total displacement, sense of slip, and geometry of this fault are difficult to evaluate because it is not exposed in the Sierra Bacha study area. However, the majority of faults mapped by Gastil and Krummenacher (1976) were interpreted as vertical structures that have since been shown to be moderately-dipping normal faults (e.g., Bennett et al., 2013a; this study). We interpret the Libertad fault to be a southwest-dipping normal fault because younger tilted units (groups 3b) west of the fault trace dip down to the northeast and are juxtaposed against older units (groups 2, 3a) east of the fault (suggesting normal slip on a southwest-dipping fault), and because other exposed, parallel faults are southwest-dipping normal faults. In structural crosssections, we infer a dip of $35^{\circ} \mathrm{SW}$ for the Libertad fault, consistent with other large-displacement normal faults in the study area (e.g., Bacha fault) and similar to the geometry of the offshore Amado fault along strike (Aragón-Arreola and Martín-Barajas, 2007; Martín-Barajas et al., 2013). We estimate total post-12.6 Ma normal displacement on the Libertad fault to be 4.0-4.8 $\mathrm{km}$ based on reconstruction of correlative outcrops of the Tuff of San Ignacio (Ttsi); $0.3-0.9$ $\mathrm{km}$ of this total occurred after $\sim 10.6 \mathrm{Ma}$ based on displacement of Tba and its maximum dip of $\sim 20^{\circ}$ at Cerro Las Burras (Figs. 4, 12B, 14).

\subsection{Pozo Coyote fault}

The Pozo Coyote fault is a NW-striking normal fault discontinuously exposed in the central study area (Fig. 4; Darin and Dorsey, 2014). Gastil and Krummenacher (1976) first identified the Pozo Coyote fault as an unnamed fault that structurally repeats an interval of undifferentiated volcanic strata. Normal displacement on the Pozo Coyote fault is variable along 
strike, ranging from $0.3-1.1 \mathrm{~km}$. It is best exposed south of the Cerro Colorado where group 2 volcanic rocks in the hanging wall are juxtaposed against tonalite basement in the footwall. At this location (UTM: 12R, 373816 E, $3269819 \mathrm{~N}$ ), the fault dips $32^{\circ} \mathrm{SW}$ and exhibits a 10-20 mthick fault breccia in its footwall. In the northwest part of the study area, the Pozo Coyote fault is inferred to continue beneath alluvium southwest of the Cerro Prieta. Alternatively, the Pozo Coyote fault may die out to the northwest, possibly losing displacement where it is cut by the NE-striking San Ignacio fault near Pozo Coyote (Fig. 4).

\subsection{Noriega fault}

The Noriega fault is a NW-striking normal fault in the southern part of the study area (Figs. 3, 4; Darin and Dorsey, 2014). This fault juxtaposes group 3b sedimentary rocks in the hanging wall against Late Cretaceous basement in the footwall along its partially concealed map trace. These syn-tectonic group $3 \mathrm{~b}$ conglomerates (e.g., Tc3) display a prominent fanning-dip sequence, where bedding dip decreases up-section from $\sim 28^{\circ} \mathrm{NE}$ to horizontal (Fig. 12C). The northwestern termination of the fault appears to be just north of Cerro Pelón where it is concealed beneath Quaternary alluvium, implying an along-strike gradient of diminishing displacement towards the northwest. Along strike to the southeast, the map-view exposure of the hanging wall basin widens as the fault continues along the east side of the Sierra Seri and beyond the study area (Fig. 3). An estimate of normal displacement is complicated by uncertainty in fault dip. Nevertheless, we estimate a maximum of $\sim 2.7-3.3 \mathrm{~km}$ of normal displacement on this fault based on reconstruction of correlative outcrops of the Tuff of San Ignacio (Ttsi) across the fault. The lower estimate assumes a maximum fault dip of $\sim 40^{\circ}$ to avoid fault to bedding cut-off angles $>90^{\circ}$ in its hanging wall (Fig. 12C); the higher end of the displacement estimate is based on a fault dip as shallow as $\sim 10^{\circ}$. Such a shallow fault dip is not observed for any other normal fault 
in the Sierra Bacha and requires unrealistic fault to bedding cut-off angles up to $\sim 120^{\circ}$. We assume no strike-slip motion on the Noriega fault for these displacement calculations.

\subsection{Bacha fault}

The Bacha fault is NW-SE-striking normal fault that dips $\sim 33^{\circ}$ to the southwest and is discontinuously exposed for $24 \mathrm{~km}$ in the study area (Fig. 4; Darin and Dorsey, 2014). The fault continues to the southeast beneath Quaternary alluvium (Fig. 4) and could either merge with the Seri fault or die out and transfer slip to the Noriega fault to the east. Hanging-wall map units dip $\sim 45-50^{\circ}$ to the NE (Fig. 12A). In the northwest part of the study area, the footwall adjacent to the Bacha fault trace consists of a 4-8 m-thick homogeneous tonalite fault breccia that is pervasively fractured and contains a matrix of dark red, clay-sized gouge. We estimate total normal displacement on the Bacha fault to be $2.6-3.4 \mathrm{~km}$ based on the reconstruction of correlative units (Tc2, Ttsf) across it (Figs. 12A and 14).

Direct evidence of strike-slip displacement on the Bacha fault has not been observed; however, indirect evidence suggests that significant strike-slip displacement is unlikely on this structure. First, the gentle dip of the fault suggests that it is not in a preferred orientation to accommodate significant strike-slip, although this does not preclude strike-slip prior to tilting of the fault to a shallow inclination. More importantly, limited-extent Ttsf exposures in the footwall and hanging wall blocks do not appear significantly offset along strike (Fig. 4). The footwall exposure of Ttsf(UTM: 12R, $371210 \mathrm{E}, 3269460 \mathrm{~N}$ ) pinches out laterally in both directions, whereas the hanging wall exposure (UTM: 12R, $367120 \mathrm{E}, 3269720 \mathrm{~N}$ ) pinches out to the south; the northern pinch-out of Ttsf is not observed there, but it does not extend more than a few kilometers to the northwest, west of the Rio San Ignacio (Fig. 4). Moreover, Ttsf is not found interbedded with exposed middle to late Miocene units anywhere else in the study area, implying 
that it was probably a distal deposit confined to narrow exposures by paleo-valleys rather than a laterally extensive blanket. Even if these two exposures do indeed represent a paleo-valley deposit, it is not suitable as a piercing line for precisely quantifying potential strike-slip displacement because its original orientation cannot be determined from the available data. However, based on these indirect data, we interpret that the proximity of the two limited-extent Ttsf exposures support insignificant strike-slip displacement on the Bacha fault.

A geologic map by Gastil and Krummenacher $(1976,1977)$ located and named the Bacha fault northwest of our study area. Field observations and interpretations of satellite imagery suggest that the feature previously mapped as the Bacha fault may instead be an unconformity between Cenozoic volcanic units and pre-Cenozoic crystalline basement (nonconformity) that Darin and Dorsey (2014) mapped in the hanging wall of the Pozo Coyote fault (Fig. 4) and continues to the northwest beyond the study area. Thus, the Bacha fault in this study should not be confused with the speculative structure of the same name interpreted by Gastil and Krummenacher $(1976,1977)$. Regardless, we interpret that the Bacha fault mapped in this study projects offshore at the same location along the Sonoran shoreline as suggested by Gastil and Krummenacher (1976, 1977) (Fig. 3). The Bacha fault may continue for an additional $\sim 50 \mathrm{~km}$ offshore (Fig. 3), where Martín-Barajas et al. (2013) mapped it as a SW-dipping structure with a $\sim 1 \mathrm{~km}$-thick sedimentary wedge in its hanging wall and interpreted it to be an oblique-slip fault with significant dextral motion.

\subsection{Seri fault}

The Seri fault is a hypothesized, concealed structure located onshore in the southwestern part of the map area (Figs. 3, 4). Gastil and Krummenacher $(1976,1977)$ first identified this NWstriking fault as a major range-bounding fault with an unknown magnitude of normal and strike- 
slip separation. Along strike to the southeast, the Seri fault may link to a domain of NW-striking faults in the Sierra Seri that are mapped as normal faults (Fig. 3; Gastil and Krummenacher, 1977; Oskin and Stock, 2003c). Along strike to the northwest, Gastil and Krummenacher (1976, 1977) did not map the Seri fault continuing offshore, but rather mapped its concealed trace continuing towards the coastal Sierra Bacha, where fault offset of intrusive basement contacts is not observed (Fig. 4; Darin and Dorsey, 2014). If the Seri fault does continue northwest of the Rio San Ignacio, its trace must be offshore (Fig. 4; Darin and Dorsey, 2014). Based on its lack of exposure and speculative nature in the study area, no inferences have been made regarding total displacement, on the Seri fault. However, because basement rocks are exhumed northeast of its trace and no bedrock exposures exist immediately west of its trace, we interpret the Seri fault to dip to the southwest and to have a substantial normal or normal-oblique component of slip (Fig. 14).

\subsection{Other Prominent Faults}

The San Ignacio fault is a NE-striking sinistral or sinistral-oblique fault in the central study area (Fig. 4). NE-dipping group 2 strata in the southern Sierra Tordilla and near Pozo Coyote display ca. 0.9 and $1 \mathrm{~km}$ of left separation, respectively. In the Sierra Tordilla, both the southwest-dipping Pozo Coyote fault and the northeast-dipping basement nonconformity and middle Miocene volcanic cover display the same amount of left separation. Identical separation of these oppositely dipping features indicates that the apparent separation is caused by sinistral strike-slip motion on the San Ignacio fault. Elsewhere, the fault is mostly concealed beneath group 4 units. Although the precise timing of slip and its relationship with the Bacha fault are uncertain, the San Ignacio fault appears to displace the Pozo Coyote, which implies that slip initiated during or after displacement on the Pozo Coyote fault. 
A series of NNE-SSW- to N-S-striking faults also display minor left separation $(<250 \mathrm{~m}$ each) indicating sinistral or sinistral-oblique normal slip at Cerro Colorado, Cerro Prieta, the Sierra Tordilla, and Lomas Ona-Jeco (Fig. 4). At Cerro Colorado, some of these faults cross-cut and offset NW-SE-striking normal faults (e.g., UTM: 12R 373974 E, 3273342 N). One E-Wstriking dextral fault at Cerro Colorado appears to be an accommodation structure facilitating differential tilting to the north and south (UTM: 12R $373160 \mathrm{E}, 3270742 \mathrm{~N}$ ).

\subsection{Fault Kinematics}

We measure fault kinematic indicators on secondary and minor faults to interpret the regional kinematic strain axes for the Sierra Bacha study area. This technique hinges on the assumption that faulting is scale-invariant, such that the kinematics of small-scale faults are representative of and analogous to that of large-scale structures (Marrett and Allmendinger, 1990). This assumption is difficult to test in the Sierra Bacha because very few fault measurements were made along or near major structures due to limited exposure. However, the average NW-SE strike (Fig. 13B) and extensional or oblique-extensional mode (Fig. 15) of minor faults is consistent with the orientation of major first-order mapped faults (Fig. 4). The similar orientations of minor and major faults in the Sierra Bacha qualitatively supports our assumption of scale-invariant faulting.

A total of 65 faults and 41 kinematic indicators were measured in middle to late Miocene units and pre-Cenozoic crystalline basement in the study area (e.g., Figs. 10B, C). Poles to measured fault surfaces form two loose clusters defining conjugate sets of moderately NE- and SW-dipping faults that both strike $\sim$ NNW-SSE (Fig. 13B). In contrast to the relatively uniform fault plane orientations, slip vectors reveal highly variable slip directions and individual kinematic axes for each fault slip datum are more heterogeneous (Fig. 15). Kinematic analysis of 
all fault slip data reveals a sub-horizontal extension axis (T-axis) oriented at azimuth $067^{\circ}$, and a sub-vertical shortening axis (P-axis), implying that the observed strain pattern in the Sierra Bacha is compatible with predominantly ENE-WSW extension with a minor dextral component since the middle Miocene (Fig. 15, bottom center). This result is consistent with independent geologic evidence for $\sim \mathrm{NE}-\mathrm{SW}$-directed extension based on our detailed geologic mapping and documentation of uniform northeastward tilting of Miocene units (Fig. 13A).

The distribution and association of kinematic axes can also provide useful information regarding the predominant deformation style. Both $\mathrm{P}$ - and T-axes define loose clusters around their mean vectors, while intermediate/null (B) axes form a girdle that mixes with and broadly follows the distribution of P-axes (Fig. 15, bottom-center). If we assume that all kinematic indicators formed in response to the same stress field, then the close association of P-and B-axes suggests that the magnitudes of the maximum and intermediate stress axes were approximately equal, such that they may have flipped orientations regularly during faulting (Fossen, 2010). This scenario in which the compression direction $(\mathrm{P})$ is either vertical or horizontal N-S while remaining $\sim 90^{\circ}$ from the extension direction $(\mathrm{T})$ is more consistent with transtension than orthogonal extension (Fossen, 2010). A possible alternative interpretation is that the kinematic heterogeneity is the result of fault reactivation under a non-uniform stress field. Unfortunately, this hypothesis is difficult to evaluate due to a lack of timing constraints from overprinting or cross-cutting relationships.

\section{PALEOMAGNETISM}

Five volcanic units, including three pyroclastic units (Ttc, Ttsf, and Ttsi) and two lava flows $(\operatorname{Tr} 2, T b a)$ were sampled in the Sierra Bacha for paleomagnetic analysis (Figs. 16, 17; 
Table 3). Based on the geomagnetic polarity timescale of Lourens et al. (2004), the isotopic ages for Ttsf ( 12.6 Ma; Stock et al., 1999) and Ttsi (12.57-12.63 Ma) indicate that these tuffs likely erupted during reversed-polarity subchron C5Ar.1r (12.415-12.730 Ma). Tba (10.59 $\pm 0.06 \mathrm{Ma})$ was likely deposited during normal-polarity subchron C5n.2n (10.826-9.968 Ma). While Ttc $(14.20 \pm 1.60 \mathrm{Ma})$ and $\operatorname{Tr} 2(11.70 \pm 0.40 \mathrm{Ma})$ each have a normal-polarity signature, uncertainty in their ages prohibit their placement into a specific geomagnetic polarity interval. Virtual Geomagnetic Poles (VGP) calculated from site-mean characteristic remanent magnetization $(\mathrm{ChRM})$ directions cluster well $\left(\alpha-95<10^{\circ}\right)$ at all five sites in the Sierra Bacha, indicating that they are very likely primary NRM components (Fig. 16; Table 3).

In general, NRM, LT, and low-AF steps show anomalous low-stability vector directions (e.g., Fig. 16B-D) that were excluded from ChRM vector analysis since they most likely represent secondary NRM components acquired after the volcanic deposit cooled below the Curie temperature. At higher AF steps (e.g., 20-80 mT) vectors showed higher stability and tended to isolate a distinct (likely primary) ChRM vector. We used PaleoMag 3.1b1 (Jones, 2002) to estimate the best line or plane fit for the demagnetization path for each specimen. Vectors from several core specimens were combined for each locality to calculate the site-mean ChRM, or virtual geomagnetic pole (VGP), and Fisher and Bingham statistics (Butler, 1992). Vertical-axis block rotations were calculated for each fault block using the methods of Beck (1980) and Demarest (1983) and by comparing each VGP to one of two calculated Miocene paleopoles (Table 3).

To quantify vertical-axis block rotations, site-mean ChRM vectors from paleomagnetic sites in the Sierra Bacha were compared with paleomagnetic reference directions (Table 3). To calculate rotation of the Ttsf site (DS-21), we compared the Ttsf paleomagnetic vector from the 
Sierra Bacha to a high-precision paleomagnetic reference vector for Ttsf from a tectonically stable location in Baja California (Bennett and Oskin, 2014). The magnetic direction of Ttsf in Baja California $\left(\mathrm{D}=212.4^{\circ}, \mathrm{I}=-3.0^{\circ}, \alpha-95=1.33^{\circ}\right)$ is unique and deviates from the expected reversed-polarity Miocene paleopole direction (inclined up-to-the-south) and appears to record a transitional field or geomagnetic excursion (Stock et al., 1999).

No stable reference site exists for Ttsi (DS-17). The site-mean ChRM for this site (D = $\left.228.2^{\circ}, \mathrm{I}=-1.3^{\circ}, \alpha-95=1.48\right)$ is similar to the unique low-inclination, magnetization direction of Ttsf, which has an identical radiometric age within standard error $(12.63 \pm 0.03$ to $12.57 \pm 0.10$ Ma for Ttsi vs. 12.6 Ma for Ttsf). Despite indistinct ages and magnetic remanence, we prefer to interpret that Ttsi and Ttsf are different lithologic units erupted from spatially distinct volcanic vents during the same transitional field or geomagnetic excursion during reversed polarity subchron C5Ar.1r (see section 4.3). Transitional fields and excursions of the geocentric dipole are characterized by large-scale secular variation and their stability is not well understood (Verosub, 1982). However, paleomagnetic data from Ttsf and adjacent rhyolite flows in the Sierra Libre north of Guaymas (Fig. 1) demonstrate the magnitude of paleosecular variation immediately before, during and after this excursion, with declinations and inclinations varying by at least $35^{\circ}$ and $60^{\circ}$, respectively (Olguín, 2013). This rapid and large magnitude instability of the geomagnetic field at this time suggests that the Ttsf reference pole may not represent the geomagnetic field orientation during emplacement of Ttsi. Thus, we do not estimate rotation for Ttsi at DS-17 because no magnetic paleopole has been established to use as a stable reference for this unit.

For the remaining three paleomagnetic sites [Ttc (DS-22), $\operatorname{Tr} 2$ (DS-23) and Tba (DS-24)], no stable reference sites exist with which to compare site-mean ChRM directions. In order to 
estimate block rotation at these sites, we use an average paleopole for Miocene volcanic rocks on Baja California (Hagstrum et al., 1987) and add a $2.3^{\circ}$ clockwise correction to account for post- 6 Ma divergence between Baja California and Sonora (cf., Oskin and Stock, 2003b), and two stable North American paleopoles (Besse and Courtillot, 1991). We average these three paleopoles to partially account for secular variation of the Earth's magnetic field during Miocene time, resulting in an estimated mean Miocene paleomagnetic pole position $\left(87.2^{\circ} \mathrm{N}, 182.6^{\circ} \mathrm{E}, \alpha-\right.$ $\left.95=8.6^{\circ}\right)$ and an expected magnetization direction of $\mathrm{D}=2^{\circ}, \mathrm{I}=49^{\circ}$ at the geographic location of the study area during Miocene time (method of Butler, 1992). The $2 \sigma$ confidence limits for declination $\left(\alpha-95[\mathrm{dec}]=19.7^{\circ}\right)$ and inclination $\left(\alpha-95[\mathrm{inc}]=25.0^{\circ}\right)$ of paleosecular variation around this calculated paleopole direction (green dashed ellipse on Fig. 16C-E) were calculated from the volcanic database of Quidelleur and Courtillot (1996) using the standard deviations of declination $\left(\sigma \mathrm{D}=15^{\circ}\right)$ and inclination $\left(\sigma \mathrm{I}=12.5^{\circ}\right)$ for latitudes $30-40^{\circ} \mathrm{N}$ via: $\alpha-95(\mathrm{dec})=$ $(2 \sigma \mathrm{D}) \cos \left(49^{\circ}\right)$ and $\alpha-95(\mathrm{inc})=(2 \sigma \mathrm{I})$.

Independent analysis of each site reveals rotation values, including uncertainty, ranging from $-15.5^{\circ}$ to $27.8^{\circ}$ (Table 3 ). In this study, positive rotation values indicate clockwise (CW) block rotation about a vertical-axis, whereas negative values indicate counter-clockwise $(\mathrm{CCW})$ rotation. Results for sites DS-22, DS-23, and DS-24 show no discernible vertical-axis rotation within standard error limits (Fig. 17). Site DS-22 (Ttc) shows $-3.1^{\circ} \pm 11.1^{\circ}$ of rotation. Six of the twelve cores collected at this site were extracted from a relatively less welded horizon in the tuff, which explains the bimodal distribution of ChRM and the higher than average site-mean $\alpha-95$ confidence limit of $9.25^{\circ}$ (Table 3). Less welded samples have inclinations $\sim 25^{\circ}$ greater than the welded samples, but declinations vary by only $\sim 3^{\circ}$ between the two ChRM populations. Site DS$23(\operatorname{Tr} 2)$ reveals $-7.0^{\circ} \pm 8.5^{\circ}$ of CCW rotation based on only five cores. Site DS-24 (Tba) shows 
$1.5^{\circ} \pm 9.0^{\circ}$ of rotation based on 12 cores (Fig. 17). Because ChRM directions for these sites are within or near expected limits of paleosecular variation (e.g., stereoplots in Fig. 16C-E), these results do not serve as evidence of vertical-axis block rotation. However, as the uncertainties in our rotation estimates show, up to $\sim 10^{\circ}$ of vertical-axis rotation (either clockwise or counterclockwise) is permissible given paleosecular variation, reflecting the large uncertainties in the position of the Miocene paleopole. The only site which displays ostensible vertical-axis rotation is site DS-21 (Ttsf) in the southwestern part of the study area where we calculate $25.4^{\circ} \pm 2.4^{\circ}$ clockwise rotation (Fig. 17).

These results suggest that vertical-axis rotation was insignificant northeast of the Bacha fault since ca. $14.2 \pm 1.6 \mathrm{Ma}$ (Fig. 17B). However, $\sim 25^{\circ}$ of clockwise vertical-axis rotation is recorded with a high level of confidence at site DS-21 in the hanging wall of the Bacha fault. Clockwise rotation at this site also corresponds with the only area where bedding strike deviates from NW to a more NNW strike, suggesting that clockwise vertical-axis rotation is restricted to the southwesternmost part of the study area (Figs. 4, 17).

\section{DISCUSSION}

\subsection{Deformation History of the Sierra Bacha}

Evidence from geologic mapping, geochronology, fault kinematic analysis, and paleomagnetism provides constraints on the magnitude, timing, and style of deformation in the Sierra Bacha since ca. 15 Ma. Here we discuss all available geologic constraints, assumptions, and uncertainties and interpret the tectonic evolution of the Sierra Bacha.

\subsubsection{Magnitude of Extension}


The magnitude of extension across the Sierra Bacha is calculated from restoration of cross section D-D' (Fig. 14). The amount of extension is constrained by dip-slip offset of paleohorizontal markers (e.g., regionally extensive ignimbrites and/or the nonconformable basement paleosurface) across major faults. Considering uncertainties based on potentially significant paleo-relief in the study area, we estimate dip-slip offsets of 4.0-4.8 km for the Libertad fault, 2.6-3.4 km for the Bacha fault, $0.3-1.1 \mathrm{~km}$ for the Pozo Coyote fault, and a total of $1.3 \mathrm{~km}$ across several unnamed normal faults in the central Cerro Colorado (Figs. 12, 14). Based on a palinspastic reconstruction of tilted fault blocks in the Sierra Bacha using a preferred combination of fault offsets, we calculate $\sim 6.1 \mathrm{~km}$ of cumulative NE-SW-directed extension, or 55-60\%, since the middle Miocene (Fig. 14).

Strata in the footwall of the Libertad fault, which are tilted up to $53^{\circ}$ to the northeast at Cerro Las Burras, suggest the presence of at least one additional concealed fault to the northeast. Similarly, the concealed Seri fault may represent the next major rift structure southwest of the Bacha fault (Fig. 4). Because this structural restoration does not include extension related to slip on, or concealed between, these presumed structures, our estimate of 55-60\% extension is only valid between the dashed black arrows on section D-D' (Fig. 14), and is unconstrained to the southwest and northeast.

Stock and Hodges (1989) estimated that total ENE-WNW directed extension in the GEP due to oblique displacement of the Pacific plate is $160 \pm 80 \mathrm{~km}$ since ca. 12 Ma. Restricting this motion entirely within the GEP would require $\sim 66 \%$ extension across the entire province (Fig. 1). Subsequent studies have pointed out that such large magnitudes of orthogonal extension have not been observed in Sonora (Gans, 1997; Henry and Aranda-Gomez, 2000) and used this as indirect evidence to postulate a more significant role of strike-slip faulting and transtensional 
strain during late Miocene time. However, our estimate of 55-60\% NE-directed extension in the Sierra Bacha is comparable to the amount predicted for the northern GEP by Stock and Hodges (1989), suggesting that margin-perpendicular extension in the GEP is not as rare as considered by some, and similar undocumented large-magnitude extension may have occurred elsewhere in Sonora.

\subsubsection{Timing of Extension}

The pronounced angular discordance between group 3a and 3b strata (Figs. 10A, 12, 14) provides an important constraint on the timing of extension-related tilting in the Sierra Bacha. Group 2 and 3a strata (ca. 14.2-11.7 Ma) are structurally concordant with an average northeast dip of $43^{\circ}$ (Fig. 13A). In contrast, group $3 \mathrm{~b}$ and 4 strata (post-11.7 Ma) unconformably overlie older units and have an average northeast dip of $11^{\circ}$ (Fig. 13A). This angular discordance suggests that extension in the Sierra Bacha began during or just prior to deposition of group $3 b$,

after ca. 11.7 Ma. This timing is supported by conglomerate clast counts that reveal an up-section increase in basement clast input, from only $16 \%$ in pre-tectonic (pre-11.7 Ma) conglomerates to $34 \%$ and $44 \%$ in syn- and post-tectonic conglomerates, respectively (Fig. 11). We interpret this notable up-section change as a signal of extensional unroofing and basement exhumation after ca. 11.7 Ma across the entire study area.

The only dated syn-tectonic (group 3b) unit is the $10.59 \pm 0.06 \mathrm{Ma}$ Basalt of Arivaipa (Tba). At Cerro Las Burras, subhorizontal Tba unconformably overlies moderately dipping group 2 and 3a strata (Fig. 4), indicating that extension northeast of the Libertad fault occurred between ca. 11.7 and 10.6 Ma. Farther to the southwest, in the hanging wall of the Libertad fault, the angular unconformity at the base of Tba dips $20^{\circ}$ to the northeast (Fig. 4). Compared to the

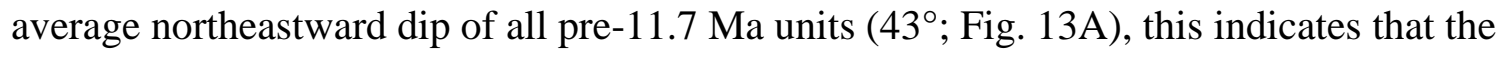


majority of extension at Cerro Colorado and Cerro Prieta took place between ca. 11.7 and 10.6 $\mathrm{Ma}$, with a rate of tilting of about $20^{\circ} / \mathrm{Myr}$. Unfortunately, direct constraints on the minimum age of extension are not available southwest of the Libertad fault. Assuming a constant strain rate and original horizontality of $T b a$, this suggests that post-10.6 Ma tilting of up to $20^{\circ}$ ended by ca. 9.6 Ma southwest of the Libertad fault. Tba is not observed in fault blocks to the southwest, such as the hanging walls of the Pozo Coyote and Bacha faults, making the timing of extension less certain there. However, our interpretation of domino-style block faulting in the study area, which is supported by uniformly northeast-tilted strata and consistent, approximately parallel strike of faults and bedding (Fig. 13), kinematically requires simultaneous tilting of adjacent structural blocks, implying that extension across the entire study area probably occurred ca. 11.7-9.6 Ma. Our interpretation that tilting ended by ca. 10.6 Ma northeast of the Libertad fault but continued until $~ 9.6$ Ma to the southwest suggests that the faults have a listric geometry at depth to accommodate post-10.6 Ma tilting. Although the ages of overlying and undeformed group 4 strata are not well known, the lack of evidence of faulting or tilting of these units suggests that the Sierra Bacha is not tectonically active today and that extension and transtension probably ended prior to the Quaternary.

Many studies in the northern GEP have documented major ENE-WSW extension ca. 12.5-6 Ma (Gastil et al., 1975; Dokka and Merriam, 1982; Henry, 1989; Stock and Hodges, 1989; Lee et al., 1996; Bennett et al., 2013a). Our interpretation that extension in the Sierra Bacha occurred from ca. 11.7 to $9.6 \mathrm{Ma}$ is consistent with nearby studies in coastal Sonora that document east-west extension from ca. 11.4 to 10.3 Ma in the Sierra Santa Ursula (MoraAlvarez and McDowell, 2000) and from ca. 10.7 to 9.3 Ma in the Sierra el Aguaje (Fig. 18; Gans et al., 2013). Apatite fission track data record rapid exhumation ca. 14-8 Ma in the Sierra 
Bachoco near Hermosillo (Fig. 18; Calmus et al., 2015), and at ca. 7 Ma along the Sonoran coast just south of Puerto Libertad (Figs. 3, 18; Calmus et al., 2000; Lugo-Zazueta, 2013), supporting the notion that extension migrated to the west or southwest across Sonora during middle to late Miocene time in coastal Sonora.

\subsubsection{Magnitude of Strike-Slip Fault Offset}

The magnitude of strike-slip fault offset is difficult to quantify in the Sierra Bacha.

Despite previous work that assumed the presence of concealed NW-SE-striking dextral faults in the Sierra Bacha region (Gastil and Krummenacher, 1976, 1977), direct evidence of strike-slip displacement on major NW-SE-striking structures has yet to be documented. The Amado transform fault was identified in offshore seismic reflection profiles as a southwest-dipping $\left(\sim 35-50^{\circ}\right)$ structure that forms the northeastern boundary of the inactive Adair-Tepoca basin offshore Puerto Libertad and projects onshore to the Libertad fault (Fig. 3; Aragón-Arreola and Martín-Barajas, 2007). Although it has been suggested that the Amado fault may have accommodated significant dextral shear during late Miocene-Pliocene time, piercing points are lacking in the offshore data. Onshore, available geologic evidence does not support significant dextral slip on the Libertad fault in the study area. Correlative outcrops of Ttsi and Tba located directly across the Libertad fault from each other do not show evidence for significant lateral separation. Furthermore, restoring any significant $(>5 \mathrm{~km})$ dextral offset on the Libertad fault to align outcrops of Tba at Cerro Las Burras with similar outcrops at Cerro Prieto would translate the thickest Ttsi deposits at Cerro Las Burras (up to $~ 300$ m-thick) to the northwest where Ttsi is not present across strike (Fig. 4). However, because these volcanic units do not serve as discrete piercing points, minor $(<5 \mathrm{~km})$ dextral displacement across the Libertad fault is permissible, although unlikely. 
Numerous N-S- to NE-SW-striking secondary faults show left separation that may be related to either down-to-the-west normal, sinistral-normal oblique, or sinistral strike-slip. The largest of these faults, the San Ignacio fault in the west-central area, strikes $\sim$ NE-SW and displays $\sim 1 \mathrm{~km}$ of sinistral separation of both the SW-dipping Pozo Coyote fault and the NEdipping basement nonconformity, indicating sinistral strike-slip rather than normal or oblique normal displacement.

Our analysis of paleomagnetic data supports a relatively small magnitude of dextral shear in the Sierra Bacha during or after late Miocene time. Structural blocks show no discernible vertical-axis rotation since ca. 14.2 Ma, except in the southwest near El Desemboque where paleomagnetic evidence and clockwise rotation of structural strikes indicate $\sim 25^{\circ}$ of clockwise rotation in the hanging wall of the southern Bacha fault (Figs. 4, 17). This block rotation does not require dextral displacement along the Bacha fault, which is unlikely to be significant based on the proximity of limited-extent Ttsf exposures interpreted as paleo-valley deposits. We speculate that block rotation in this area may be related to minor dextral shear between the Bacha fault and the concealed Seri fault. Dextral slip on the Seri fault is unknown but plausible due to its proximity to the offshore De Mar-Sacrificio transform fault (Mar-Hernandez et al., 2012; MartínBarajas et al., 2013), which forms the NE boundary of the CSFZ (Fig. 3), a narrow zone of significant localized dextral strain between ca. 7 and 6 Ma (Bennett et al., 2013a).

In summary, evidence from detailed geologic mapping and paleomagnetic data suggest that strike-slip faulting played a relatively minor role in the deformation history of the Sierra Bacha. Fault kinematic data support a component of dextral transtension following major extension, but other direct evidence of dextral shear is lacking. Despite this, we estimate that up to $\sim 6 \mathrm{~km}$ of NW-SE-directed dextral shear is permissible, although unlikely, on exposed faults in 
the study area (i.e., between the hanging wall of the Bacha fault and the footwall of the Libertad fault). This includes $0-5 \mathrm{~km}$ of permissible offset to restore Tba outcrops across the Libertad fault and probably $<1 \mathrm{~km}$ for clockwise block rotation of Ttsf in the hanging wall of the Bacha fault, the latter of which is based on the geometric relationship between the approximate width of the fault block and the magnitude of paleomagnetic vertical-axis rotation. This result is remarkable in that it contrasts sharply with evidence of at least $41 \pm 11 \mathrm{~km}$ or as much as $\sim 100$ $\mathrm{km}$ of late Miocene dextral shear in the CSFZ located just southwest of and adjacent to the Sierra Bacha (Fig. 3; Bennett et al., 2013a; Vidal-Solano et al., 2013).

\subsubsection{Timing of Strike-Slip Faulting and Transtension}

Although the exact timing of transtensional shear and strike-slip faulting is poorly constrained, paleomagnetic data and cross-cutting map relationships provide useful insight. Paleomagnetic data indicate negligible vertical-axis block rotations at Cerro Colorado and Cerro Las Burras since ca. 10.6 Ma (Fig. 17). Low to moderate clockwise block rotation recorded in Ttsf at DS-21 indicates that dextral shear near the shoreline must have occurred after ca. 12.6 Ma. At Cerro Colorado, several NNE-SSW- to N-S-striking faults with minor left separation cross-cut and offset NE-tilted strata and several major SW-dipping normal faults (Fig. 4; Darin and Dorsey, 2014), suggesting they post-date initial extension. The geometry of these leftseparation faults are compatible with predicted secondary normal or sinistral faults within a NWoriented dextral or dextral transtensional wrench system (Sanderson and Marchini, 1984) such as the Gulf of California oblique rift (Withjack and Jamison, 1986).

Our fault kinematic data set is limited in size and lacks both overprinting relationships and kinematic data from major structures, and thus does not provide much information about the timing of strike-slip faulting or transtensional deformation. Note, however, that major normal 
faults in the Sierra Bacha that currently dip $\sim 30-35^{\circ}$ where exposed have been tilted along with middle Miocene volcanic strata by $\sim 40^{\circ}$ as a result of domino-style block faulting, implying that major faults had initially steep dips of $\sim 70-75^{\circ}$ to the southwest. In contrast, the majority of measured minor fault surfaces currently dip $>55^{\circ}$ (Fig. 13B; Supplementary Table S4). Thus, it seems that minor faults used in our kinematic analysis have not been affected by the same magnitude of tilting as major faults and strata in the Sierra Bacha. An excellent example of this can be seen in the proximal footwall of the Bacha fault where minor fault surfaces are arranged in steeply-dipping conjugate sets that strike NW-SE (Fig. 10C). These fault orientations are consistent with the predictions of Andersonian mechanics for newly initiated faults (Anderson, 1951) and thus imply that they post-date major tilting and extension in the Sierra Bacha.

Collectively, these observations suggest that any strike-slip and/or transtensional faulting occurred after significant extension-related tilting in the Sierra Bacha. Thus, our preferred interpretation is that the Sierra Bacha experienced relatively minor transtensional strain either during the later stages or following extension from ca. 11.7 to $9.6 \mathrm{Ma}$, and this transtensional strain was highest near the Sonoran shoreline.

\subsubsection{Summary of Deformation History}

Significant domino-style block faulting between ca. 11.7 and 10.6 Ma resulted in 5560\% NE-SW-directed extension in the Sierra Bacha. Extension ended at ca. 10.6 Ma northeast of the Libertad fault, and possibly by ca. 9.6 Ma at Cerro Colorado and Cerro Prieta. A minimum age for extension is uncertain farther southwest along the coastal ranges, but exhumation may have occurred as late as ca. $7 \mathrm{Ma}$ based on published apatite fission track thermochronology along the Sonoran coast $\sim 20 \mathrm{~km}$ northwest of the Sierra Bacha (Calmus et al., 2000; Lugo- 
Zazueta, 2013). Thus, we interpret that extension likely shut down systematically from northeast to southwest across the study area during the late Miocene.

Although currently undocumented, we estimate that $0-6 \mathrm{~km}$ of dextral shear is permissible on mapped faults, suggesting that dextral shear was insignificant across most of the study area. Fault kinematic data are interpreted to reflect relatively minor dextral transtension either following or during the latest stages of extension. Modest clockwise vertical-axis block along the Bacha fault suggests a greater influence of dextral shear concentrated in the southwest near the modern Sonoran shoreline, likely during late-stage deformation in the Sierra Bacha.

\subsection{Transtensional Strain in the Northern Gulf Extensional Province}

Geological and geophysical data across northwestern México, summarized previously (see section 2), suggest up to $\sim 150-250 \mathrm{~km}$ of dextral shear across the northern GEP ca. 12.5-6 Ma. Here we summarize recent studies that constrain the distribution, timing, and kinematics of faulting. These studies provide a growing body of evidence for dextral shear, rapid transtensional deformation, and basin development east of the Baja California microplate during latest Miocene time.

In the Salton Trough, northwest of and along strike from the northern Gulf of California, geochronology and stratigraphy of the Fish Creek-Vallecito Basin record the onset of transtension-related extension on the West Salton detachment fault ca. $\sim 8.0 \pm 0.4 \mathrm{Ma}$ (Dorsey et al., 2011). Geologic studies in the adjacent Mojave Desert and Eastern Transverse Ranges of southern California suggest that plate boundary dextral shear in the Eastern California shear zone initiated ca. 10-5 Ma (Dokka and Travis, 1990; Schermer et al., 1996; Dokka et al., 1998). Along strike to the southeast near the U.S.-México border in northwestern Sonora, offset Tertiary geologic markers reveal $\sim 50 \mathrm{~km}$ of dextral shear across a series of NW-striking strike-slip faults 
inferred to be late Cenozoic strands of the southern San Andreas fault system, although the precise timing of dextral shear is not well constrained (Nourse et al., 2005).

Farther south along the Pacific-North America plate boundary, additional evidence supports a late Miocene onset for transtensional deformation from both margins of the northern Gulf of California. In northeastern Baja California, apatite fission track and (U-Th)/He data, fault kinematics and stratigraphic relationships along an en-echelon series of detachment faults suggest that rapid footwall exhumation and transtensional strain initiated between $\sim 9$ and $7 \mathrm{Ma}$ in the Sierra San Felipe (Fig. 18; Seiler et al., 2010, 2011, 2013). On the conjugate rifted margin in Sonora (Fig. 3), geologic mapping, fault kinematics, paleomagnetic data, and geochronology of volcanic rocks document the onset of significant transtensional deformation ca. 8-7 Ma in the CSFZ near Bahía de Kino (Bennett et al., 2013a) and on northeastern Isla Tiburón (Bennett, 2013). The CSFZ, which accommodated a minimum of $41 \pm 11 \mathrm{~km}$ of dextral displacement during latest Miocene time, continues offshore to the northwest as the De Mar fault (MarHernandez et al., 2012; Martín-Barajas et al., 2013) along the northeastern margin of the Lower Tiburón basin (Figs. 3, 18). Strike-slip faulting and related basin formation initiated ca. 7 Ma on the La Cruz fault on southern Isla Tiburón (Fig. 18; Bennett et al., this special volume).

Southeast of and along strike with the CSFZ, paleomagnetic data from 20-8.8 Ma volcanic units in the Sierra el Aguaje near Guaymas (Fig. 1), show substantial clockwise vertical-axis block rotations of $13-105^{\circ}$ (Herman, 2013). These data are interpreted as evidence of significant transtensional strain from 11.9 to 9 Ma. However, this interpretation is problematic because $9 \mathrm{Ma}$ lava flows record $\sim 90^{\circ}$ of clockwise rotation (Herman, 2013, p.23), suggesting that nearly all shear-related block rotation in this region probably occurred after ca. 9 Ma (Fig. 18). Farther southeast, incipient oblique opening of the offshore Guaymas Basin was ongoing by ca. 7 
Ma, based on tectonic reconstructions and the pull-apart basin geometry of a thick offshore evaporite deposit and its correlation to 7 Ma gypsum beds exposed onshore on the conjugate rifted margin in central Baja California (Miller and Lizarralde, 2013).

The Sierra el Aguaje coastal domain is bound to the northeast by the Coastal Sonora fault zone and to the southwest by NW-striking dextral faults, such as the Tiburón transform and the La Cruz fault on southern Isla Tiburón (Figs. 3, 18). Marine seismic reflection data suggests that basins related to activity on the offshore Tiburón transform initiated in late Miocene time (Aragón-Arreola et al., 2005). Geologic mapping of the La Cruz fault has constrained the onset of strike-slip faulting and syn-tectonic basin formation on southern Isla Tiburón to $\sim 8-7 \mathrm{Ma}$ (Bennett et al., this volume).

Altogether, observations of late Miocene transtension in the northern GEP do not support the end-member strain partitioning model of Stock and Hodges (1989), which proposes that late Miocene (ca. 12-6 Ma) strain was purely extensional and orthogonal to the Pacific-North America plate boundary (Fig. 2A). However, evidence of predominantly orthogonal extension on both conjugate rift margins during early proto-Gulf time (e.g., Lee et al., 1996; Lewis and Stock, 1998; Mora-Alvarez and McDowell, 2000; Umhoefer et al., 2002; Bennett et al. 2013; this study) and the delayed inception of significant dextral shear until ca. 8-7 Ma (e.g., Bennett, 2009; Dorsey et al., 2011; Seiler et al., 2011, 2013; Bennett et al., 2013a; Miller and Lizzaralde, 2013; Bennett et al., this volume) indicate that dextral shear was not ubiquitous throughout the GEP as suggested by the distributed transtension model (Fig. 2B; Fletcher et al., 2007). Hence, an intermediate, or hybrid model for proto-Gulf kinematics is required to reconcile the existing geologic and geophysical data.

\subsection{Progressive Localization Model}


Geologic evidence from the Sierra Bacha supports an intermediate model of proto-Gulf kinematics involving the progressive localization of dextral shear starting at ca. 8-7 Ma (cf. Bennett, 2009; Seiler, 2009; Seiler et al., 2011; Bennett et al., 2013a; Bennett and Oskin, 2014). According to this model (Fig. 2C), Pacific-North America plate boundary dextral shear became focused within the Gulf of California shear zone (GCSZ), a narrow corridor of transtensional deformation that caused significant crustal thinning, hosted the Gulf of California marine seaway, and led to rupture of continental lithosphere (Bennett and Oskin, 2014). The GCSZ developed during latest Miocene time due to the onset of a $\sim 12^{\circ}$ clockwise shift in the azimuth of Pacific-North America plate motion at ca. 8 Ma (Atwater and Stock, 1998, 2013), and focused strain into a narrow, incipient transtensional belt of discrete dextral shear zones. The initiation of dextral shear in a narrow zone was followed by an increase in strain rates (e.g., Oskin et al., 2001) that mechanically weakened the crust and permitted large-magnitude extension in pullapart basins now located in the eastern Gulf of California. Thermal insulation and overpressure due to rapid and voluminous sedimentation from the Colorado River since ca. 5.3 Ma (Dorsey, 2010; Dorsey et al., 2007, 2011) promoted hyperextension via detachment faulting and lower crustal flow that apparently delayed lithospheric rupture and seafloor spreading in the early rift basins (Gastil and Fenby, 1991; Martín-Barajas et al., 2013). As a result, significant oblique plate boundary strain migrated westward into transtensional basins now located in the western Gulf of California (Aragón-Arreola and Martín-Barajas, 2007), where focused transtensional strain eventually facilitated lithospheric rupture in the northern Gulf of California by ca. 2-1 Ma (Martín-Barajas et al., 2013).

When integrated with other studies in the region (e.g., Seiler et al., 2010, 2011, 2013; Dorsey et al., 2011; Bennett et al., 2013a; Miller and Lizarralde, 2013; Herman, 2013), the lack 
of significant dextral shear in the Sierra Bacha may indicate that dextral shear and/or transtension was not distributed over a broad region during late Miocene time, but instead was restricted to the GCSZ, along the southwestern margin of the Sierra Bacha study area. If significant dextral shear occurred elsewhere in Sonora, it may have been well inland of the CSFZ, in interior Sonora, rather than immediately adjacent to and northeast of the CSFZ. Approximately $40 \mathrm{~km}$ ESE of the Sierra Bacha, paleomagnetic data from presumed middle Miocene dikes near Rancho Nuevo (Fig. 3) reveal clockwise vertical-axis rotations that are interpreted as evidence of ca. 1312 Ma shear (García-Martínez, et al., 2014). However, the magnitude and geometry of the causative structures are speculative and incompletely documented, the basement dikes that may record dextral warping remain undated and could record pre-Miocene deformation, and no crosscutting relationship (e.g., angular unconformity, undeformed capping unit) has been documented to serve as a minimum age constraint on the deformation.

Based on the above data and regional synthesis, we propose a modified kinematic model for the evolution of fault activity in the northern GEP that involves the progressive localization of plate boundary dextral shear into the proto-Gulf of California rift between ca. 12.5 and $6 \mathrm{Ma}$ (Fig. 18). Early oblique motion (ca. 12.5-8 Ma) between the Baja California microplate and the Sierra Madre Occidental (i.e., stable North America) occurred as extension-dominated transtension oriented $\sim$ NE-SW in the Sierra Bacha (this study), and $\sim$ E-W across coastal Sonora (e.g., Mora-Alvarez and McDowell, 2000; Vidal-Solano et al., 2008; Bennett et al., 2013a; Gans et al., 2013; Herman, 2013; Olguín, 2013) and slightly farther inland near Hermosillo (e.g., Vidal-Solano et al., 2008; Calmus et al., 2015). By ca. 8-7 Ma deformation began incorporating significant dextral shear across the CSFZ, possibly involving the speculative Seri fault offshore Sierra Bacha, and by ca. 7-6 Ma it evolved into more focused, shear-dominated transtension in 
the CSFZ that probably continued into early modern Gulf time ( 6-5 Ma). In the nascent Gulf of California (ca. 7-6 Ma), incipient NW-striking strike-slip faults offshore the Sierra Bacha (e.g., De Mar, Bacha, and Amado faults) were likely linked to N- to NNW-striking normal faults (Fig. 3) in the Sonora continental shelf (Martín-Barajas et al., 2013) and on northeastern Isla Tiburón (Bennett, 2013). Dextral strain was transferred to the southwest across these normal and obliquenormal faults to en-echelon, right-stepping dextral shear zones including other strike-slip faults in the CSFZ (Yawassag, Sacrificio, Bahía Kino, Infernillo faults), and potentially to the La Cruz and Tiburón transform faults via normal faults offshore western Isla Tiburón (Fig. 18; MarHernandez et al., 2012; Martín-Barajas et al., 2013; Bennett, 2013). Progressive localization of dextral shear along these incipient, kinematically-linked transtensional structures and basins within the GCSZ at ca. 8-6 Ma may have been responsible for late-stage dextral transtension and the general lack of significant dextral shear on the onshore projections of these faults (e.g., Libertad and Bacha faults) in the adjacent Sierra Bacha.

The central and northern Walker Lane in eastern California and western Nevada represents a useful modern analog in both scale and kinematics for the ca. 7-6 Ma GCSZ (Fig. 18; Bennett and Oskin, 2014). Similar to the latest Miocene GCSZ, the Walker Lane is a narrow transtension belt characterized by dextral and normal faulting, vertical-axis block rotations, synrift volcanism, and transtensional basin formation embedded within the western margin of an extensional domain (Basin and Range Province) and adjacent to a relatively undeformed and stable microplate (Sierra Nevada) (e.g., Wesnousky, 2005; Faulds and Henry, 2009; Bennett and Oskin, 2014).

\subsection{Implications for Regional Tectonic Evolution}


Existing constraints on the distribution, magnitude, and timing of strain in the northern Gulf of California offer insight into possible mechanisms responsible for the ca. 4-5 million year delay between the end of subduction west of Baja California (ca. $12 \mathrm{Ma}$ ) and the onset of focused dextral shear and transtension at ca. $8 \mathrm{Ma}$ in the GEP. The timing of this change from extension-dominated to shear-dominated transtension in the northern GEP is broadly coincident with a subtle but kinematically significant change to more oblique Pacific-North America relative plate motion in the global plate circuit model (Atwater and Stock, 1998, 2013), as pointed out by geologic studies in the GEP (e.g., Seiler et al., 2011; Bennett et al., 2013a; Bennett et al., this volume). According to the plate circuit model, the azimuth of Pacific-North America relative motion increased from $\sim 300^{\circ}$ to $\sim 312^{\circ}$ at the latitude of the Sierra Bacha from ca. 8 to $6 \mathrm{Ma}$. If we take the average orientation of the Pacific-North America plate boundary to be $\sim 330^{\circ}$ at $8 \mathrm{Ma}$ (Bennett et al., 2013b), then this change in relative plate motion corresponds to a change in $\alpha$ (the acute angle between the average orientation of the plate boundary and the direction of relative plate motion) from $\sim 30^{\circ}$ to $\sim 18^{\circ}$ over a 2 Myr period. Analog models of oblique rifts reveal distinct differences in the style of faulting between independent models where $\alpha=30^{\circ}$ and $\alpha=15^{\circ}$, and they specifically predict reactivation and reconfiguration of fault networks and the formation of through-going strike-slip faults at $\alpha=15^{\circ}$ (Withjack and Jamison, 1986; Clifton et al., 2000; Agostini et al., 2009; Brune, 2014). These models suggest that a similar increase in rift obliquity in the GEP may have enhanced the efficiency of strike-slip faults when plate motion became more parallel to the Pacific-North America plate boundary after ca. 8 Ma. This change in relative plate motion and rift obliquity may also explain the change from extension-dominated to shear-dominated transtensional fault kinematics proposed in the progressive localization model (Fig. 2C). For example, the NE-SW-directed extension we 
document in the Sierra Bacha likely became inactive at, or shortly after, 9.6 Ma. Collectively, these data suggest a causal link between the degree of rift obliquity and the potential for strain localization and subsequent lithospheric rupture, as proposed previously by proponents of a progressive localization model (Bennett, 2009; Seiler, 2009; Seiler et al., 2011; Bennett and Oskin, 2014).

Another possible hypothesis is that the 3-5 Myr delay between the end of subduction and the initiation of widespread transtension along the entire length of the GEP was somehow related to the late arrival of hot asthenosphere that may have weakened the lower crust and initiated localized deformation (e.g., Fletcher et al., 2007; Seiler et al., 2011). Carter et al. (2004, 2006) proposed a similar mechanism in which thermal weakening related to the passage of slab windows facilitated extreme crustal thinning and rapid exhumation of metamorphic core complexes in the Colorado River extensional corridor during the middle Miocene. Development of an appropriate mechanical model that describes the four-dimensional evolution of the protoGulf of California rift will require improved constraints on the timing and distribution of transtensional strain in the GEP from both continental and offshore marine basins.

\section{CONCLUSIONS}

New geologic mapping, geochronology, fault kinematics, and paleomagnetic data reveal the style and magnitude of late Miocene rifting in the Sierra Bacha of coastal Sonora. A > $2 \mathrm{~km}-$ thick composite sequence of middle to late Miocene volcanic and volcaniclastic rocks are cut by a series of SW-dipping normal faults and are uniformly tilted down-to-the-northeast. A palinspastic reconstruction of a structural cross section across the entire study area reveals that domino-style block faulting resulted in 55-60\% NE-SW-directed extension primarily between 
ca. 11.7 and 9.6 Ma, which shut down from northeast to southwest across the study area. Fault kinematic data are interpreted to reflect relatively minor dextral transtension either following or during the latest stages of extension. Paleomagnetic data reveal no clockwise vertical-axis rotations, except for $\sim 25^{\circ}$ of clockwise rotation near the modern shoreline and adjacent to the offshore projection of the Coastal Sonora fault zone, which is known to have accommodated significant dextral transtension during latest Miocene time.

We develop a modified model of progressive localization of the Pacific-North America plate boundary in the northern GEP between ca. 12.5 and $6 \mathrm{Ma}$ as the plate margin in northwestern México transitioned from subduction to oblique rifting (Fig. 18). Initial oblique rifting appears to have involved extension-dominated transtension from ca. 12 to $9 \mathrm{Ma}$ throughout the northern proto-Gulf, including moderate NE-SW-directed extension in the Sierra Bacha until $\sim 9$ Ma. By $\sim 8$ Ma, extension had ended in the Sierra Bacha and deformation evolved into more localized, shear-dominated dextral transtension in the adjacent Gulf of California shear zone, a > $1000 \mathrm{~km}$-long, 50-100-km-wide deformation belt that hosted focused transtensional strain during latest Miocene time and kinematically connected to the NNW with the incipient southern San Andreas fault system and eastern California shear zone. Dextral shear in the Gulf of California shear zone greatly accelerated at about 7-6 Ma, contemporaneous with a clockwise shift in Pacific-North America relative plate motion that began at $\sim 8 \mathrm{Ma}$ and reduced the rift angle from $\sim 30^{\circ}$ to $\sim 18^{\circ}$ by $6 \mathrm{Ma}$, effectively increasing the degree of rift obliquity. This change permitted the development of strike-slip faults and likely played a role in localizing PacificNorth America relative plate motion into the northern GEP. Progressive localization of the dextral component of the Pacific-North America plate boundary into the transtensional northern Gulf of California accelerated strain rates and focused crustal thinning and extension in 
intervening pull-apart basins that led to marine incursion at ca. 6.3 Ma and eventual continental rupture in the northern Gulf of California.

\section{ACKNOWLEDGMENTS}

Funding from the National Science Foundation (grant EAR-0738723 to Dorsey, EAR0739017 and EAR-0904337 to Oskin), a UC MEXUS grant to Oskin, and a Geological Society of America Graduate Student Research Grant to Darin made this research possible. Constructive and thorough reviews by Joann Stock and Christian Seiler have greatly improved the quality of this manuscript, and early reviews and discussions with Marli Miller, Ray Weldon, David Blackwell, and Joann Stock were particularly helpful. Carl Swanson, Eric Loes and Mike Tappa provided great assistance and company during field work in the Sonoran desert. Special thanks to Dan Miggins at the Oregon State University Geochronology Lab for his incredible effort to provide new geochronological data for us in time for the revision of this manuscript. We are grateful to Mick Kunk for his assistance and guidance while running the ${ }^{40} \mathrm{Ar} /{ }^{39} \mathrm{Ar}$ samples at the U.S. Geological Survey Thermochronology lab in Reston, Virginia. Aldo Izaguirre and Harim Arvizu (both at UNAM) are greatly acknowledged for their help preparing mineral separates and obtaining SEM-CL images at the U.S. Geological Survey in Denver, Colorado. We thank Tom Donovan, John Sheedy and everyone at the Prescott College Kino Bay Center for Cultural and Ecological Studies in Bahía de Kino, Sonora for logistical support and accommodations, and Joe Kirschvink, Sarah Slotznick, and Steve Skinner at the Caltech Paleomagnetics Laboratory for assistance and use of their equipment. We offer sincere thanks to Ernesto Molina and the native Comcáac (Seri) tribe of western Sonora, México for granting access to the study area. 


\section{REFERENCES CITED}

Abbott, P.L., and Smith, T.E., 1989, Sonora, México, source for the Eocene Poway Conglomerate of southern California: Geology, v. 17, p. 329-332, doi:10.1130 /0091-7613(1989)017<0329:SMSFTE>2.3.CO;2.

Agostini, A., Corti, G., Zeoli, A., and Mulugeta, G., 2009, Evolution, pattern, and partitioning of deformation during oblique continental rifting: inferences from lithospheric-scale centrifuge models: Geochemistry Geophysics Geosystems, v. 10, Q11015.

Allmendinger, R. W., Cardozo, N. C., and Fisher, D., 2012, Structural Geology Algorithms: Vectors \& Tensors: Cambridge, England, Cambridge University Press, 289 p.

Anderson, E.M., 1951, The Dynamics of Faulting and Dyke Formation with Applications to Britain, 2nd Edition: Oliver and Boyd, Edinburgh, UK.

Andersen, T., 2002, Correction of common lead in U-Pb analyses that do not report ${ }^{204} \mathrm{~Pb}$ : Chemical Geology, v. 192, p. 59-79.

Anderson, T.H., and Silver, L.T., 1969, Mesozoic magmatic events of the northern Sonora coastal region, México: Geological Society of America Abstracts with Programs, v. 1 , p. 3.

Angelier, J., 1994, Fault slip analysis and palaeostress reconstruction (Chapter 4), in Continental Deformation, P. L. Hancock, ed., Pergamon Press, Oxford, 53-100.

Aragón-Arreola, M., and Martín-Barajas, A., 2007, Westward migration of extension in the northern Gulf of California, México: Geology, v. 35, no. 6, p. 571-574, doi:10.1130/G23360A.1.

Aragón-Arreola, M., Morandi, M., Martín-Barajas, A., Deldago-Argote, L., and GonzálezFernández, A., 2005, Structure of the rift basins in the central Gulf of California: Kinematic implications for oblique rifting: Tectonophysics, v. 409, p. 19-38, doi:10.1016/j.tecto.2005.08.002.

Atwater, T., 1970, Implications of plate tectonics for the Cenozoic evolution of western North America: Geological Society of America Bulletin, v. 81, p. 3513-3536.

Atwater, T., and Stock, J., 1998, Pacific North America plate tectonics of the Neogene southwestern United States: An update: International Geology Review, v. 40, no. 5, p. 375-402, doi:10.1080/00206819809465216.

Atwater, T.M., and Stock, J.M., 2013, Constraints on the history of the late Cenozoic PacificNorth American plate boundary from marine magnetic anomalies and global plate circuits: Geological Society of America Abstracts with Programs, v. 45, no. 6, p. 21. 
Beck, M.E., 1980, Paleomagnetic record of plate-margin tectonic processes along the western edge of North America: Journal of Geophysical Research, v. 85, p. 7115-7131.

Bennett, S.E.K., 2009, Transtensional rifting in the late proto-Gulf of California near Bahía Kino, Sonora, México [M.S. thesis]: Chapel Hill, University of North Carolina, 122 p.

Bennett, S.E.K., 2013, The role of rift obliquity in formation of the Gulf of California [Ph.D. thesis]: Davis, University of California-Davis, 220 p.

Bennett, S.E.K., and Oskin, M.E., 2014, Oblique rifting ruptures continents: Example from the Gulf of California shear zone: Geology, v. 42, p. 215-218, doi: 10 .1130 /G34904 .1 .

Bennett, S.E.K., Oskin, M.E., and Iriondo, A., 2013a, Transtensional rifting in the proto-Gulf of California, near Bahía Kino, Sonora, México: Geological Society of America Bulletin, v. 125, p. 1752-1782, doi:10.1130/B30676.1.

Bennett, S.E., Skinner, L.A., Darin, M.H., Umhoefer, P.J., Oskin, M.E., and Dorsey, R.J., 2013b, New constraints on Baja California-North America relative plate motion since $11 \mathrm{Ma}$ American Geophysical Union Fall Meeting, San Francisco, California, abstract \# T14C02B.

Bennett, S.E.K., Oskin, M.E., Dorsey, R.J., Iriondo, A., and Kunk, M.J., 2015, Stratigraphy and structural development of the southwest Isla Tiburón marine basin: Implications for latest Miocene tectonic opening and flooding of the northern Gulf of California: Geosphere, v. 11, no. 4, doi:10.1130/GES01153.1.

Bennett, S.E.K., Oskin, M.E., Iriondo, A., and Kunk, M.J., Slip history of the La Cruz fault: development of a late Miocene transform in response to increased rift obliquity in the northern Gulf of California: Tectonophysics, this volume

Besse, J., and Courtillot, V., 1991, Revised and synthetic apparent polar wander paths of the African, Eurasian, North-American and Indian plates, and true polar wander since 200 Ma: Journal of Geophysical Research, v. 96, p. 4029-4050.

Brune, S., 2014, Evolution of stress and fault patterns in oblique rift systems: 3-D numerical lithospheric-scale experiments from rift to breakup: Geochemistry, Geophysics, Geosystems, v. 15 , no. 8, p. 3392-3415.

Bryant, B.A., 1986, Geology of the Sierra Santa Rosa Basin, Baja California, México [M.S. thesis]: San Diego, California, San Diego State University, 75 p.

Buck, W.R., 1991, Modes of Continental Lithospheric Extension: Journal of Geophysical Research, v. 96, p. 20161-20178, doi:10.1029/91JB01485.

Buck, W.R., Lavier, L.L., and Poliakov, A.N.B., 1999, How to make a rift wide: Philosophical 
Transactions of the Royal Society of London Series a - Mathematical Physical and Engineering Sciences, v. 357, p. 671-690.

Butler, R.L., 1992, Paleomagnetism: Cambridge, Massachusetts, Blackwell Scientific Publications, $319 \mathrm{p}$.

Calmus, T., Poupeau, G., Defaux, J., and Labrin, E., 2000, Basin and Range and Gulf of California tectonics: contribution of an apatite fission-track study, in Calmus, T., and Pérez-Segura, E., eds., Cuarta Reunión Sobre la Geología del Noroeste de México y Areas Adyacentes: Universidad Nacional Autónoma de México, Instituto de Geología, Estación Regional del Noroeste y Universidad de Sonora, Departamento de Geología, Libro de Resúmenes, Publicaciones Ocasionales, v. 2, p. 13-14.

Calmus, T., Bernet, M., Lugo-Zazueta, R., Hardwick, E., and Mendivil-Quijada, H., 2015, Apatite fission-track thermochronology of Laramide plutonic rocks in northwestern México: distinguishing Basin and Range extension from Gulf of California rifting: Revista Mexicana de Ciencias Geológicas, v. 32, no. 3, p. 529-541.

Carter, T.J., Kohn, B.P., Foster, D.A., and Gleadow, A.J.W., 2004, How the Harcuvar Mountains metamorphic core complex became cool: Evidence from apatite (U-Th)/He thermochronometry: Geology, v. 32, no. 11, p. 985-988, doi:10.1130/G20936.1.

Carter, T.J., Kohn, B.P., Foster, D.A., Gleadow, A.J.W., and Woodhead, J.D., 2006, Late-stage evolution of the Chemehuevi and Sacramento detachment faults from apatite (U-Th)/He thermochronometry-Evidence for mid-Miocene accelerated slip: Geological Society of America Bulletin, v. 118, p. 689-709, doi: 10.1130/B25736.1.

Cardozo, N., and Allmendinger, R.W., 2013, Spherical projections with OSXStereonet: Computers \& Geosciences, v. 51, no. 0, p. 193-205, doi:10.1016/j.cageo.2012.07.021.

Clifton, A.E., Schlische, R.W., Withjack, M.O., and Ackermann, R.V., 2000, Influence of rift obliquity on fault-population systematics: results of experimental clay models: Journal of Structural Geology, v. 22, no. 10, p. 1491-1509.

Darin, M.H., and Dorsey, R.J., compilers, 2014, Geologic map of the Sierra Bacha, coastal Sonora, México: Geological Society of America Digital Map and Chart Series 21, doi:10.1130/2014.DMCH021.

Demarest, H.H., 1983, Error analysis for the determination of tectonic rotation from paleomagnetic data: Journal of Geophysical Research, v. 88, no. B5, p. 4321-4328.

DeMets, C., and Dixon, T.H., 1999, New kinematic models for Pacific-North America motion from 3 Ma to present, I: Evidence for steady motion and biases in the NUVEL-1A model: Geophysical Research Letters, v. 26, no. 13, p. 1921-1924.

Doblas, M., 1998, Slickenside kinematic indicators: Tectonophysics, v. 295, p. 187-197. 
Dokka, R.K., and Merriam, R.H., 1982, Late Cenozoic extension of northeastern Baja California, México: Geological Society of America Bulletin, v. 93, p. 371-378.

Dokka, R.K. and Travis, C.J., 1990, Late Cenozoic strike-slip faulting in the Mojave Desert, California: Tectonics, v. 9, no. 2, p. 311-340.

Dokka, R.K., Ross, T.M. and Lu, G., 1998, The Trans-Mojave-Sierran shear zone and its role in Early Miocene collapse of southwestern North America: in Holdsworth, R.E., Dewey, J.F., and Strachan, R.A., eds., Continental Transpressional and Transtensional Tectonics: Geological Society of London Special Publication 135, p. 183-202.

Dorsey, R.J., 2010, Sedimentation and crustal recycling along an active oblique-rift margin: Salton Trough and northern Gulf of California: Geology, v. 38, no. 5, p. 443-446, doi:10.1130/G30698.1.

Dorsey, R.J., and Burns, B., 1994, Regional stratigraphy, sedimentology, and tectonic significance of Oligocene-Miocene sedimentary and volcanic rocks, northern Baja California, México: Sedimentary Geology, v. 88, no. 3-4, p. 231-251.

Dorsey, R., Fluette, A., McDougall, K., Housen, B., Janecke, S., Axen, G., and Shirvell, C., 2007, Chronology of Miocene-Pliocene deposits at Split Mountain Gorge, Southern California: A record of regional tectonics and Colorado River evolution: Geology, v. 35, p. 57-60, doi:10.1130/G23139A.1.

Dorsey, R.J., Housen, B.A., Janecke, S.U., Fanning, C.M., and Spears, A.L.F., 2011, Stratigraphic record of basin development within the San Andreas fault system: Late Cenozoic Fish Creek-Vallecito basin, southern California: Geological Society of America Bulletin, v. 123, p. 771-793.

Faulds, J.E., and Henry, C.D., 2008, Tectonic influences on the spatial and temporal evolution of the Walker Lane: An incipient transform fault along the evolving Pacific - North American plate boundary, in Spencer, J.E., and Titley, S.R., eds., Ores and orogenesis: Circum-Pacific tectonics, geologic evolution, and ore deposits: Arizona Geological Society Digest, v. 22, p. 437-470.

Fenby, S.S., and Gastil, R.G., 1991, A seismo-tectonic map of the Gulf of California and surrounding areas, in Dauphin, J.P., and Simoneit, B.R., eds., The Gulf and Peninsular Provinces of the Californias: Tulsa, Oklahoma, The American Association of Petroleum Geologists Memoir 47, p. 79-83.

Fisher, R.A., 1953, Dispersion on a sphere: Proceedings of the Royal Society of London, Series A, v. 217, p. 295-305.

Fletcher, J.M., Grove, M., Kimbrough, D., Lovera, O., and Gehrels, G.E., 2007, Ridge-trench interactions and the Neogene tectonic evolution of the Magdalena shelf and southern Gulf 
of California: Insights from detrital zircon $\mathrm{U}-\mathrm{Pb}$ ages from the Magdalena fan and adjacent areas: Geological Society of America Bulletin, v. 119, no. 11-12, p. 1313-1336, doi:10.1130/B26067.1.

Fossen, H., 2010, Structural Geology: Cambridge University Press, Cambridge, 463 p.

Gans, P.B., 1997, Large-magnitude Oligo-Miocene extension in southern Sonora: Implications for the tectonic evolution of northwest México: Tectonics, v. 16, no. 3, p. 388-408.

Gans, P.B., S. Herman, and I. MacMillan, 2013, Late Miocene (12-6 Ma) transtensional faulting, block rotations, and volcanism during the inception of the Gulf of California oblique rift, southwestern Sonora, México: Geological Society of America Abstracts with Programs, v. 45 , no. 6 , p. 21 .

García-Martínez, D., Molina Garza, R.S., Roldán Quintana, J., and Mendívil-Quijada, H., 2014, Ca. 13 Ma strike-slip deformation in coastal Sonora from a large-scale, en-echelon, brittle-ductile, dextral shear indicator: implications for the evolution of the California rift: Geofísica Internacional, v. 53, no. 4, p. 435-456.

Gastil, R.G., 1993, Prebatholithic history of peninsular California, in Gastil, R.G., and Miller, R.H., eds., The prebatholithic stratigraphy of peninsular California: Geological Society of America Special Paper 279, p. 145-156.

Gastil, R.G., and Fenby, S.S., 1991, Detachment faulting as a mechanism for tectonically filling the Gulf of California during dilation, in Dauphin, J.P., and Simoneit, B.R.T., eds., The Gulf and Peninsular Province of the Californias: American Association of Petroleum Geologists Memoir, v. 47, p. 371-375.

Gastil, R.G., and Krummenacher, D., 1976, Reconnaissance geologic map of coastal Sonora between Puerto Lobos and Bahía Kino: Geological Society of America Map and Chart Series MC-16, scale 1:150,000, 1 sheet.

Gastil, R.G., and Krummenacher, D., 1977, Reconnaissance geology of coastal Sonora between Puerto Lobos and Bahía Kino: Geological Society of America Bulletin, v. 88, p. 189-198.

Gastil, R.G., Lemone, D.V., and Stewart, W.J., 1973, Permian fusulinids from near San Felipe, Baja California: American Association of Petroleum Geologists Bulletin, v. 57, no. 4 , p. 746-747.

Gastil, R.G., Krummenacher, D., Doupont, J., and Bushee, J., 1974, The batholith belt of southern California and western México: Pacific Geology, v. 8, p. 73-78.

Gastil, R.G., Phillips, R.P., Allison, E.C., 1975, Reconnaissance geology of the state of Baja California: Geological Society of America Memoir 140, 170 p. 
Gastil, R.G., Krummenacher, D., and Minch, J., 1979, Record of Cenozoic volcanism around the Gulf of California: Geological Society of America Bulletin, v. 90, no. 9, p. 839-857.

Gold, R.D., Briggs, R.W., Personius, S.F., Crone, A.J., Mahan, S.A., and Angster, S.J., 2014, Latest Quaternary paleoseismology and evidence of distributed dextral shear along the Mohawk Valley fault zone, northern Walker Lane, California: Journal of Geophysical Research: Solid Earth, v. 119, no. 6, p. 5014-5032.

González-Fernández, A., Danobeitia, J.J., Deldago-Argote, L., Michaud, F., Cordoba, D., and Bartolome, R., 2005, Mode of extension and rifting history of upper Tiburón and upper Delfín basins, northern Gulf of California: Journal of Geophysical Research, v. 110, p. 117, doi:10.1029/2003JB002941.

González-León, C.M., Valencia, V., López, M., Bellon, H., Valencia Moreno, M.A., and Calmus, T., 2010, The Arizpe sub-basin: Sedimentary and magmatic evolution of the Basin and Range in north-central Sonora, México: Revista Mexicana de Ciencias Geológicas, v. 27, p. 292-312.

Hagstrum, J.T., Sawlan, M.G., Hausback, B.P., Smith, J.G., and Gromme, C.S., 1987, Miocene Paleomagnetism and tectonic setting of the Baja California peninsula, México: Journal of Geophysical Research, v. 92, no. B3, p. 2627-2639.

Hausback, B.P., 1984, Cenozoic volcanic and tectonic evolution of Baja California Sur, México, in Frizzell, V.A., Jr., ed., Geology of the Baja California peninsula, v. 39: Los Angeles, California, Society of Economic Paleontologists and Mineralogists, Pacific Section, p. 219-236.

Heine, C., and Brune, S., 2014, Oblique rifting of the Equatorial Atlantic: Why there is no Saharan Atlantic Ocean: Geology, v. 42, p. 211-214, doi:10.1130/G35082.1.

Henry, C.D., 1989, Late Cenozoic basin and range structure in western México adjacent to the Gulf of California: Geological Society of America Bulletin, v. 101, no. 9, p. 1147-1156.

Henry, C.D., and Aranda Gomez, J.J., 1992, The real southern basin and range: Mid Cenozoic to late Cenozoic extension in México: Geology, v. 20, p. 701-704, doi:10.1130/00917613(1992)020<0701:TRSBAR>2.3.CO;2.

Herman, S.W., 2013, A paleomagnetic investigation of vertical-axis rotations in coastal Sonora, México: Evidence for distributed transtensional deformation during the Proto-Gulf shift from a subduction-dominated to transform-dominated plate boundary in the Gulf of California [M.S. thesis]: Santa Barbara, University of California-Santa Barbara, 39 p.

Jones, C.H., 2002, User-driven integrated software lives: "PaleoMag” Paleomagnetics Analysis on the Macintosh: Computers and Geosciences, v. 28, no. 10, p. 1145-1151.

Karig, D.E., and Jensky, W., 1972, Proto-Gulf of California: Earth and Planetary Science Letters, 
v. 17 , no. 1 , p. $169-174$.

Kirschvink, J.L., 1980, The least-squares line and plane and the analysis of paleomagnetic data: Geophysical Journal of the Royal Astronomical Society, v. 62, no. 3, p. 699-718.

Kirschvink, J.L., Kopp, R.E., Raub, T.D., Baumgartner, C.T., and Holt, J.W., 2008, Rapid, precise, and high-sensitivity acquisition of paleomagnetic and rock-magnetic data: Development of a low-noise automatic sample changing system for superconducting rock magnetometers: Geochemistry Geophysics Geosystems, v. 9, no. 5, 18 p.

Lee, J., Miller, M.M., Crippen, R., Hacker, B., and Vazquez, J.L., 1996, Middle Miocene extension in the Gulf extensional province, Baja California: Evidence from the southern Sierra Juarez: Geological Society of America Bulletin, v. 108, no. 5, p. 505-525.

Lewis, C.J., 1996, Stratigraphy and geochronology of Miocene and Pliocene volcanic rocks in the Sierra San Fermín and southern Sierra San Felipe, Baja California, México: Geofísica Internacional, v. 35 , no. 1, p. 3-25.

Lewis, C.J., and Stock, J.M., 1998, Late Miocene to recent transtensional tectonics in the Sierra San Fermín, northeastern Baja California, México: Journal of Structural Geology, v. 20, no. 8, p. 1043-1063.

Lizarralde, D., Axen, G.J., Brown, H.E., Fletcher, J. M., González-Fernández, A., Harding, A. J., Holbrook, W. S., Kent, G. M., Paramo, P., Sutherland, F., and Umhoefer, P. J., 2007, Variation in styles of rifting in the Gulf of California: Nature, v. 448, no. 7152, p. 466469.

Lonsdale, P., 1989, Geology and tectonic history of the Gulf of California, in Winterer, E.L., Hussong, D.M., and Decker, R.W., eds., The eastern Pacific Ocean and Hawaii: Boulder, Colorado, Geological Society of America, Geology of North America, v. N, p. 499-521.

Lonsdale, P., 1991, Structural pattern of the Pacific floor offshore peninsular California, in Dauphin, J.P., and Simoneit, B.R.T., eds., The Gulf and the Peninsular Provinces of the Californias: Tulsa, Oklahoma, The American Association of Petroleum Geologists Memoir 47, p. 87-125.

Lourens, L., Hilgen, F., Shackleton, N.J., Laskar, J., and Wilson, D., 2004, The Neogene Period, in Gradstein, F.M., Ogg, J.G., and Smith, A.G., eds., A Geologic Time Scale 2004: Cambridge University Press, p. 409-440.

Ludwig, K.L., 2003, ISOPLOT, version 3.00, A Geochronological Toolkit for Microsoft Excel: Berkeley Geochronology Center, Special Publication No. 4, 70 p.

Lugo-Zazueta, R., 2013, Thermochronology of the Basin and Range and Gulf of California 
extensional provinces, Sonora, México [Ph.D. thesis]: The University of Melbourne, Victoria, Australia, School of Earth Sciences, 286 pp.

Mammerickx, J., and Klitgord, K.D., 1982, Northern East Pacific Rise - Evolution from 25 m.y. B.P. to the present: Journal of Geophysical Research, v. 87, p. 6751-6759.

Mar-Hernández, E., González-Escobar, M., and Martín-Barajas, A., 2012, Tectonic framework of Tiburón Basin, Gulf of California, from seismic reflection evidence: International Geology Review, v. 54, p. 1271-1283, doi:10.1080/00206814.2011.636988.

Marrett, R. A., and Allmendinger, R. W., 1990, Kinematic analysis of fault-slip data: Journal of Structural Geology, v. 12, p. 973-986.

Martín-Barajas, A., González-Escobar, M., Fletcher, J.M., Pacheco, M., Oskin, M., and Dorsey, R., 2013, Thick deltaic sedimentation and detachment faulting delay the onset of continental rupture in the northern Gulf of California: Analysis of seismic reflection profiles: Tectonics, v. 32, p. 1294-1311, doi:10.1002/tect.20063.

McDougall, K.A., Poore, R.Z., and Matti, J.C., 1999, Age and paleoenvironment of the imperial formation near San Gorgonio Pass, southern California: The Journal of Foraminiferal Research, v. 29, p. 4-25.

Michaud, F., Sosson, M., Royer, J.-Y., Chabert, A., Bourgois, J., Calmus, T., Mortera, C., BigotCormier, F., Bandy, W., Dyment, J., Pontoise, B., and Sichler, B., 2004, Motion partitioning between the Pacific plate, Baja California and the North America plate: The Tosco-Abreojos fault revisited: Geophysical Research Letters, v. 31, p. 4, doi:10.1029/2004GL019665.

Michaud, F., Royer, J.Y., Bourgois, J., Dyment, J., Calmus, T., Bandy, W., Sosson, M., MorteraGutiérrez, C., Sichler, B., Rebolledo-Viera, M., and Pontoise, B., 2006, Oceanic-ridge subduction vs. slab break off: Plate tectonic evolution along the Baja California Sur continental margin since 15 Ma: Geology, v. 34, p. 13-16, doi: 10.1130/G22050.1.

Miller, N.C., and Lizarralde, D., 2013, Thick evaporites and early rifting in the Guaymas Basin, Gulf of California: Geology, v. 41, p. 283-286, doi:10.1130/G33747.1.

Mora-Alvarez, G., and McDowell, F.W., 2000, Miocene volcanism during late subduction and early rifting in the Sierra Santa Ursula of western Sonora, México, in Delgado-Granados, H., Aguirre-Díaz, G., and Stock, J.M., eds., Cenozoic tectonics and volcanism of México: Boulder, Colorado, Geological Society of America Special Paper 334, p. 123-141.

Nagy, E.A., 2000, Extensional deformation and paleomagnetism at the western margin of the Gulf Extensional Province, Puertecitos Volcanic Province, northeastern Baja California, México: Geological Society of America Bulletin, v. 112, p. 857-870.

Nagy, E.A., Grove, M., and Stock, J.M., 1999, Age and stratigraphic relationships of pre- 
and syn-rift volcanic deposits in the northern Puertecitos Volcanic Province, Baja California, México: Journal of Volcanology and Geothermal Research, v. 93, p. 1-30.

Nourse, J.A., Anderson, T.H., and Silver, L.T., 1994, Tertiary metamorphic core complexes in Sonora, northwestern México: Tectonics, v. 13, p. 1161-1182.

Nourse, J.A., Premo, W.R., Iriondo, A., and Stahl, E.R., 2005, Contrasting Proterozoic basement complexes near the truncated margin of Laurentia, northwestern Sonora-Arizona international border region: in Anderson, T., Nourse, J., McKee, J., and Steiner, M., eds., The Mojave-Sonora megashear hypothesis: development, assessment, and alternatives: Geological Society of America Special Paper 393, p. 123-182.

Olguín-Villa, A.E., 2013, Establecimiento de la estratigrafía magnética del evento volcánico hiperalcalino del Mioceno Medio en la Sierra Libre, Sonora, México [M.S. thesis]: Departament of Geology, University of Sonora, México, 76 p.

Oskin, M.E., 2002, Part I. Tectonic Evolution of the Northern Gulf of California, México, Deduced from Conjugate Rifted Margins of the Upper Delfín Basin [Ph.D. thesis]: Pasadena, California, California Institute of Technology, 481 p.

Oskin, M., Stock, J., and Martín-Barajas, A., 2001, Rapid localization of Pacific-North America plate motion in the Gulf of California: Geology, v. 29, no. 5, p. 459-462.

Oskin, M., and Stock, J., 2003a, Marine incursion synchronous with plate-boundary localization in the Gulf of California: Geology, v. 31, no. 1, p. 23-26.

Oskin, M., and Stock, J., 2003b, Pacific-North America plate motion and opening of the Upper Delfín Basin, northern Gulf of California, México: Geological Society of America Bulletin, v. 115, p. 1173-1190.

Oskin, M., and Stock, J., 2003c, Cenozoic volcanism and tectonics of the continental margins of the Upper Delfín basin, northeastern Baja California and western Sonora, in Kimbrough, D.L., Johnson, S.E., Paterson, S., Martín-Barajas, A., Fletcher, J.M., and Girty, G., eds., Tectonic evolution of northwestern México and the southwestern USA: Geological Society of America Special Paper 374:, p. 421-428

Petit, J.P., 1987, Criteria for the sense of movement on fault surfaces in brittle rocks: Journal of Structural Geology, v. 9, no. 5/6, p. 597-608.

Plattner, C., Malservisi, R., Dixon, T.H., LaFemina, P., Sella, G.F., Fletcher, J.M., and SuarezVidal, F., 2007, New constraints on relative motion between the Pacific plate and Baja California microplate (México) from GPS measurements: Geophysical Journal International, v. 170, p. 1373-1380, doi:10.1111/j.1365-246X.2007.03494.x.

Quidelleur, X., and Courtillot, V., 1996, On low-degree spherical harmonic models of paleosecular variation: Physics of the Earth and Planetary Interiors, v. 95, no. 1-2, p. 55- 
77.

Ramos-Velázquez, E., Calmus, T., Valencia, V., Iriondo, A., Valencia-Moreno, M., and Bellon, H., 2008, U-Pb and ${ }^{40} \mathrm{Ar} /{ }^{39} \mathrm{Ar}$ geochronology of the coastal Sonora batholith: New insights on Laramide continental arc magmatism: Revista Mexicana De Ciencias Geológicas, v. 25, no. 2, p. 314-333.

Richard, P., and Krantz, R.W., 1991, Experiments on fault reactivation in strike-slip mode: Tectonophysics, v. 188, no. 1-2, p. 117-131.

Sanderson, D., and Marchini, R.D., 1984, Transpression: Journal of Structural of Geology, v. 6, p. $449-458$.

Sawlan, M.G., 1991, Magmatic evolution of the Gulf of California rift, in Dauphin, J.P., and Simoneit, B.R.T., eds., The Gulf and the Peninsular Provinces of the Californias: Tulsa, Oklahoma, The American Association of Petroleum Geologists Memoir 47, p. 301-370.

Schermer, E.R., Luyendyk, B.P., and Cisowski, S., 1996, Late Cenozoic structure and tectonics of the northern Mojave Desert: Tectonics, v. 15, no. 5, p. 905-932.

Seiler, C., Fletcher, J.M., Quigley, M.C., Gleadow, A.J.W., Kohn, B.P., 2010, Neogene structural evolution of the Sierra San Felipe, Baja California: Evidence for proto-gulf transtension in the Gulf extensional province?: Tectonophysics, v. 488, p. 87-109.

Seiler, C., Fletcher, J.M., Kohn, B.P., Gleadow, A.J.W., and Raza, A., 2011, Lowtemperature thermochronology of northern Baja California, México: Decoupled slipexhumation gradients and delayed onset of oblique rifting across the Gulf of California: Tectonics, v. 30, no. 3, TC3004.

Seiler, C., Quigley, M.C., Fletcher, J.M., Phillips, D., Gleadow, A.J.W., and Kohn, B.P., 2013, Stratigraphy and ${ }^{40} \mathrm{Ar} /{ }^{39} \mathrm{Ar}$ geochronology of the Santa Rosa basin, Baja California: Dynamic evolution of a constrictional rift basin during oblique extension in the Gulf of California: Basin Research, v. 25, no. 4, p. 388-418.

Sláma, J., Koŝler, J., Condon, D.J., Crowley, J.L., Gerdes, A., Hanchar, J.M., Horstwood, M.S.A., Morris, G.A., Nasdala, L., Norberg, N., Schaltegger, U., Schoene, B., Tubrett, M.N., Whitehouse, M.J., 2008, Pleŝovice zircon - A new natural reference material for $\mathrm{U}-\mathrm{Pb}$ and Hf isotopic microanalysis: Chemical Geology, v. 249, p. 1-35.

Spencer, J.E., and Normark, W.R., 1979, Tosco-Abreojos fault zone: A Neogene transform plate boundary within the Pacific margin of southern Baja California: Geology, v. 7, p. 554557.

Stock, J.M., 1989, Sequence and geochronology of Miocene rocks adjacent to the Main 
Gulf Escarpment: Southern Valle Chico, Baja California Norte, México: Geofísica Internacional, v. 28, p. 851-896.

Stock, J.M., and Hodges, K.V., 1989, Pre-Pliocene extension around the Gulf of California and the transfer of Baja California to the Pacific plate: Tectonics, v. 8, no. 1, p. 99-115.

Stock, J.M. and Lee, J., 1994, Do microplates in subduction zones leave a geologic record?: Tectonics, v. 13, no. 6, p. 1472-1487.

Stock, J.M., Martín-Barajas, A., Suárez-Vidal, F., and Miller, M.M., 1991, Miocene to Holocene extensional tectonics and volcanic stratigraphy of northeastern Baja California, México, in Walawender, M.J., and Hanan, B.B., eds., Geological Excursions in Southern California and México, Guidebook for the 1991 Annual Meeting of the Geological Society of America: San Diego, California, San Diego State University, p. 44-67.

Stock, J.M., Lewis, C.J., and Nagy, E.A., 1999, The Tuff of San Felipe: an extensive middle Miocene pyroclastic flow deposit in Baja California, México: Journal of Volcanology and Geothermal Research, v. 93, no. 1-2, p. 53-74.

Sutherland, F.H., Kent, G.M., Harding, A.J., Umhoefer, P.J., Driscoll, N.W., Lizarralde, D., Fletcher, J.M., Axen, G.J., Holbrook, W.S., González-Fernández, A., and Lonsdale, P., 2012, Middle Miocene to early Pliocene oblique extension in the southern Gulf of California: Geosphere, v. 8, p. 752-770, doi:10.1130/GES00770.1.

Tron, V., and Brun, J., 1991, Experiments on oblique rifting in brittle-ductile systems: Tectonophysics, v. 188, p. 71-84. doi:10.1016/0040-1951(91)90315-J.

Umhoefer, P.J., 2011, Why did the southern Gulf of California rupture so rapidly?-Oblique divergence across hot, weak lithosphere along a tectonically active margin: GSA Today, v. 21, no. 11, p. 4-10, doi:10.1130/G133A.1.

Umhoefer, P.J., and Stone, K.A., 1996, Description and kinematics of the southeast Loreto basin fault array, Baja California Sur, México: A positive field test of oblique-rift models: Journal of Structural Geology, v. 18, p. 595-614.

Umhoefer, P.J., Mayer, L., Dorsey, R.J., 2002, Evolution of the margin of the Gulf of California, Baja California Peninsula, México: Geological Society of America Bulletin, v. 114, no. 7, p. 849-868.

Verosub, K.L., 1982, Geomagnetic excursions - A critical assessment of the evidence as recorded in sediments of the Brunhes epoch: Philosophical Transactions of the Royal Society of London, Series A, v. 306, no. 1492, p. 161-168.

Vidal-Solano, J.R., Paz-Moreno, F.A., Iriondo, A., Demant, A., and Cochemé, J.J., 2005, Middle Miocene peralkaline ignimbrites in the Hermosillo region (Sonora, Mexico): Geodynamic implications: C. R. Geoscience, v. 337, p. 1421-1430. doi:10.1016/j.crte.2005.08.007 
Vidal-Solano, J.R., Lapierre, H., Stock, J.M., Demant, A., Paz-Moreno, F.A., Bosch, D., Brunet, P., and Amortegui, A., 2008, Isotope geochemistry and petrogenesis of peralkaline Middle Miocene ignimbrites from central Sonora: relationship with continental break-up and the birth of the Gulf of California: Bulletin de la Société Géologique de France, v. 179 , no. 5, p. 453-464.

Vidal-Solano, J.R., Lozano Santa Cruz, R., Zamora, O., Mendoza-Cordova, A., and Stock, J.M., 2013, Geochemistry of the extensive peralkaline pyroclastic flow deposit of NW México, based on conventional and handheld X-ray fluorescence. Implications in a regional context: Journal of Iberian Geology, v. 39, no. 1, p. 121-130.

Wernicke, B., and Axen, G.J., 1988, On the role of isostasy in the evolution of normal fault systems: Geology, v. 16, p. 848-851.

Wesnousky, S.G., 2005, The San Andreas and Walker Lane fault systems, western North America: Transpression, transtension, cumulative slip and the structural evolution of a major transform plate boundary: Journal of Structural Geology, v. 27, no. 8, p. 15051512.

Wilson, D., McCrory, P., and Stanley, R., 2005, Implications of volcanism in coastal California for the Neogene deformation history of western North America: Tectonics, v. 24, TC3008, 22 p., doi:10.1029/2003TC001621.

Withjack, M.O., and Jamison, W.R., 1986, Deformation produced by oblique rifting: Tectonophysics, v. 126, no. 2-4, p. 99-124.

Wong, M., and Gans, P., 2003, Tectonic implications of early Miocene extensional unroofing of the Sierra Mazatán metamorphic core complex, Sonora, México: Geology, v. 31, no. 11, p. 953-956.

Zoback, M.D., 1991, State of stress and crustal deformation along weak transform faults: Philosophical Transactions of the Royal Society of London, Series A, v. 337, no. 1645, p. $141-150$.

\section{FIGURE CAPTIONS}

Figure 1. Regional tectonic map of the Pacific-North America plate boundary in northwestern México and the southwestern United States. Green dashed lines represent inactive plate boundaries, including the former trench related to Farallon-North America subduction and stalled Pacific-Farallon spreading ridges and related microplates. Subduction of the Farallon plate and related microplates ended by ca. $12.5-12 \mathrm{Ma}$, leading to plate boundary reorganization from ca. 12.5 to $6 \mathrm{Ma}$. Solid red lines indicate the modern plate boundary, which accommodates modern oblique rifting and opening of the Gulf of California. Abbreviations: BK - Bahía Kino, E Ensenada, G - Guaymas, GM - Guadalupe microplate; LP - La Paz, M - Mazatlan, MM - 
Magdalena microplate; P - Puertecitos, PP - Puerto Peñasco, SF - San Felipe, SR - Santa Rosalía, SBf - San Benito fault, TAf - Tosco-Abreojos fault.

Figure 2. Alternative kinematic models for the timing and distribution of extension and dextral shear related to evolution of the Gulf of California since ca. 12.5 Ma. Active faults during each time period are shown in red. Darker colored regions are relatively undeformed. The ca. pre-12.5 Ma subduction boundary is dashed in green. BCM - Baja California microplate; GEP - Gulf Extensional Province; RTJ - Rivera Triple Junction; SMO - Sierra Madre Occidental. The 6-0 Ma ("Modern Gulf") panel is the same in each model: transtension since ca. 6 Ma has occurred almost entirely within the oblique Gulf of California rift. (A) "Strain partitioning" model in which proto-Gulf (12.5-6 Ma) strain was partitioned between offshore dextral shear and orthogonal extension in the GEP (Stock and Hodges, 1989). (B) "Distributed transtension" model which proposes a single stage of diffuse and integrated transtensional strain from offshore west of Baja California to the interior of the North American continent within the GEP since ca. $12 \mathrm{Ma}$ (Fletcher et al., 2007). (C) "Progressive localization" model (Bennett, 2009; Seiler, 2009; Seiler et al., 2011; Bennett et al., 2013a; Bennett and Oskin, 2014; this study) in which early proto-Gulf strain (ca. 12.5-9 Ma) was partitioned according to the strain partitioning model, followed by the progressive localization of dextral shear into the proto-Gulf of California during latest Miocene time ( 9-6 Ma).

Figure 3. Regional tectonic map of the coastal Sonora study region showing onshore and offshore rift-related structures and basins. Faults are from Oskin (2002), Aragón-Arreola and Martín-Barajas (2007), Mar-Hernandez et al. (2012); Bennett et al. (2013a), Martín-Barajas et al. (2013), and this study. The Coastal Sonora fault zone (CSFZ; orange) hosted a significant amount of dextral shear and clockwise block rotations during latest Miocene time (Bennett et al., 2013a). The spatial and temporal distribution of dextral shear in adjacent areas like the Sierra Bacha (blue box) has not been documented prior to this study. $\mathrm{Bf}$ - Bacha fault, $\mathrm{BKf}$ - Bahía Kino fault, If - Infernillo fault, Nf - Noriega fault, PCf - Pozo Coyote fault, Sf - Sacrificio fault; Yf - Yawassag fault.

Figure 4. Simplified geologic map of the Sierra Bacha (see Figs. 1 and 3 for location). All geochronologic data are reported at the 2- $\sigma$ confidence level (see Table 1). A detailed, 1:30,000scale version of this map is available through the Geological Society of America's Digital Map and Chart Series (Darin and Dorsey, 2014).

Figure 5. Schematic stratigraphic correlation chart of geologic units in the Sierra Bacha. Stratal geometries and depositional relationships are diagrammatic and not to scale. New geochronological data from this study are labeled in red (see Table 1); published ages for Ttsf (Stock et al., 1999) and Ttsi and Tba (Gastil and Krummenacher, 1977) are labeled in blue. See text for brief descriptions of key units; the reader is referred to Darin and Dorsey (2014) for map relationships and detailed descriptions of each unit.

Figure 6. Bulk geochemical data for middle to late Miocene volcanic units in the Sierra Bacha (see Table 2 for XRF major- and trace-element data). (A) Total alkali versus silica diagram. All samples show high total alkali concentrations $>6 \mathrm{wt} \%$. (B) Comparison of bulk rock trace element data for the 12.6 Ma tuffs of San Ignacio (Ttsi) and San Felipe (Ttsf). Ttsf in the Sierra 
Bacha (green hexagon) correlates strongly with other published geochemical data for Ttsf from Baja California and coastal Sonora (open green circles). Chemical zoning associated with rheomorphism (' $\mathrm{R}$ ') may explain variations in trace element content between the two Ttsi samples (blue squares).

Figure 7. U-Pb geochronological ages calculated for volcanic rocks from the Sierra Bacha. (A) Tera-Wasserburg U-Pb concordia plot (left) and plot of individual ${ }^{206} \mathrm{~Pb} /{ }^{238} \mathrm{U}$ ages (right) of analyzed zircon grains for Tuff of Cerro Colorado sample SON10-356 (Ttc) located near the base of the $\sim 2 \mathrm{~km}$-thick volcanic section at Cerro Colorado. (B) Tera-Wasserburg U-Pb concordia plot (left) and weighted averages of individual ${ }^{206} \mathrm{~Pb} /{ }^{238} \mathrm{U}$ ages (right) of analyzed zircons for Tuff of San Ignacio sample SON10-346 (Ttsi). (C) Tera-Wasserburg U-Pb concordia plots (left and center) and weighted averages of individual ${ }^{206} \mathrm{~Pb} /{ }^{238} \mathrm{U}$ ages (right) of analyzed zircons for dacite sample SON10-363 (Td2). In all concordia plots, solid-line ellipses with black square centers are data used for age calculations; gray-line ellipses are data excluded from age calculations due to different degrees of Pb-loss or zircon inheritance. All mean ages are reported at $2 \sigma$ uncertainty level. See Supplemental Table S1 for U-Pb single-crystal zircon analytical data. MSWD - mean square of weighted deviates.

Figure 8. Field photographs of upper group 2 ( 12.6 Ma) ignimbrites in the Sierra Bacha. (A) Typical appearance of the Tuff of San Felipe (Ttsf) west of Cerro Pelón. Note eutaxitic foliation defined by flattened white pumice fiamme and a single large, glassy trachyte-rhyolite inclusion containing abundant plagioclase (dashed circle). View is looking northeast. Marker is $13.5 \mathrm{~cm}-$ long for scale. (B) Looking southeast at the basal contact (arrows) of the Tuff of San Ignacio (Ttsi). The densely welded facies (below "Ttsi" label) forms resistant outcrops throughout the Sierra Bacha. Geologist (circled) is $\sim 1.7 \mathrm{~m}$ tall for scale. (C) Looking northwest at the densely welded zone a few meters above the base of Ttsi at Cerro Colorado. Eutaxitic foliation dips moderately towards the northeast and is defined by 1-3 cm-long, white to pink, flattened pumice fiamme. Hammer is $32.5 \mathrm{~cm}$-long for scale. (D) Rheomorphic flow structures in Ttsi at Cerro Las Burras where this unit is up to $300 \mathrm{~m}$-thick. Pumice are completely replaced by secondary quartz and irregularly folded and stretched up to $40 \mathrm{~cm}$ in length. Dark, vesicular trachyandesite inclusions (dashed circles) are up to $4 \mathrm{~cm}$ in diameter. View is towards the northeast. Marker is $13.5 \mathrm{~cm}$-long for scale.

Figure 9. ${ }^{40} \mathrm{Ar} /{ }^{39} \mathrm{Ar}$ geochronologic ages calculated for volcanic rocks in the Sierra Bacha. Uncertainty is reported at $2 \sigma$ level for all data and graphs. (A) Age probability diagram for single crystal sanidine laser total fusions for ignimbrite sample SON10-348 (Ttsi). (B) K/Ca ratios and age spectrum diagram (left) and inverse isochron diagram (right) for basaltic andesite sample SE-03-06 (Ta3). Gray shaded letters indicate step-heating steps excluded from the isochron age calculation. (C) Percent ${ }^{40} \mathrm{Ar} *$ (radiogenic Ar), K/Ca ratios, and age probability diagrams of multiple single-grain total fusion ages of sanidine crystals (left) and inverse isochron diagram (right) for rhyolite sample SON10-360 (Tr2). (D) Age probability diagram for laser total fusions on basalt sample SON15-2 (Tba). See Supplemental Tables S2 \& S3 for ${ }^{40} \mathrm{Ar} /{ }^{39} \mathrm{Ar}$ analytical data. MSWD - mean square of weighted deviates.

Figure 10. Field photographs showing structural features of the Sierra Bacha. (A) East-northeast to southeast-facing panorama of eastern Cerro Colorado showing faults (red), bedding form lines 
(dotted white), bedding attitudes (black) and the angular unconformity between group $3 \mathrm{a}$ and $3 \mathrm{~b}$ strata (dashed white line). Southwest-dipping normal faults tilted the entire section uniformly down-to-the-northeast between ca. 11.7 and 9.6 Ma, although the minimum age of tilting is poorly constrained farther southwest (see text for discussion). (B) Typical polished and striated fault surface in the study area. This fault cuts an upper group 2 welded tuff at Cerro Las Burras and dips steeply towards the southwest. Fault striae plunge very steeply $\left(\sim 90^{\circ}\right)$ and small secondary fractures subparallel to fault strike indicate that the missing block (i.e., hanging wall) moved down (white arrow), indicating normal displacement for this fault. (C) NW-SE-striking, steeply-dipping conjugate faults in Late Cretaceous tonalite basement less than 4 meters from the Bacha fault (just out of view to the right/southwest). Kinematic indicators at this outcrop consistently plunge very steeply and indicate normal displacement. The orientation of these conjugate faults imply a vertical maximum principal stress, suggesting that these minor faults have not been involved in, and thus post-date, domino-style tilting of major structures (e.g., Bacha fault) to shallower dips.

Figure 11. Clast count data for conglomerate units in the study area. Note significant increase in basement clast modal content up-section from average of $\sim 16 \%$ in pre-tectonic conglomerates to $44 \%$ in post-tectonic conglomerates. We interpret this signal to be related to tectonic unroofing and basement exhumation during late Miocene extension.

Figure 12. Geologic cross sections across the Sierra Bacha (see Fig. 4 for locations). Inclinations of concealed faults (map trace covered by alluvium) could not be measured directly, but are assumed to be parallel to those nearby. High fault-to-bedding cut-off angles (up to 80$100^{\circ}$ ) and shallowly dipping faults (consistent with field measurements of exposed structures) are inferred for concealed structures. Group 2 (purple) and group 3a (orange) units deposited between ca. 14.2 and $11.7 \mathrm{Ma}$ dip moderately and uniformly northeast. In contrast, group $3 \mathrm{~b}$ units (brown and gray) dip less steeply to the northeast and display a fanning dip interval from $28-0^{\circ}$ in section C-C', indicating that extension occurred at ca. 11.7-10.6 Ma northeast of the Libertad fault, and continued for an uncertain amount of time farther southwest. Refer to Figs. 4 and 5 for legend and an explanation of lithologic groups and abbreviations.

Figure 13. Equal area stereoplots (left) and symmetrical rose diagrams (right) of bedding (A) and fault (B) orientations in the Sierra Bacha. Dashed ellipses in all diagrams are $\alpha-95$ confidence cone limits for mean vectors (larger squares). (A) Bedding poles from pre-tectonic units (solid squares; $n=196)$ show an average pole (solid red square) that corresponds to an average bedding dip of $43^{\circ} \mathrm{NE}$ (solid red great circle); poles to syn- and post-tectonic units (open squares; $n=30$ ) reveal an average bedding plane (open red square) with the same mean strike but a much shallower dip of only $13^{\circ} \mathrm{NE}$ (dashed red great circle). (B) Poles to measured brittle faults $(n=65)$. Kamb contour interval is $2 \sigma$ and significance level is $3 \sigma$. Faults were differentiated into east-dipping (blue) and west-dipping (red) populations and contoured separately due to the bimodal distribution of poles defining a conjugate set of NE- and SW-dipping faults. Note that the average strike of all bedding (A) is nearly identical to the average strike of faults (B) shown by red arrows in the rose diagrams.

Figure 14. Balanced (above) and restored (below) cross section D-D' across the Sierra Bacha; see Fig. 4 for location. This structural restoration, which assumes a single generation of slightly 
listric domino-style normal faults, reveals $\sim 6.1 \mathrm{~km}(55-60 \%)$ of cumulative NE-SW-directed extension since ca. 11.7 Ma (see text for discussion). Refer to Figs. 4 and 5 for legend and an explanation of lithologic groups and abbreviations.

Figure 15. Equal area stereoplots of fault kinematic data and analysis from minor faults in the Sierra Bacha. Small black dots are slip vectors and small arrows indicate direction of hanging wall movement; P-axes (blue dots) and T-axes (red dots) are shown for each fault datum. Classification of fault type is based on the slip vector rake for each fault datum as shown in the plot of fault dip vs. rake (center left). Kamb contours of kinematic axes (bottom center) have a contour interval of $2 \sigma$ and a significance level of $3 \sigma$. Fault data with an inferred sense of shear are shown as unfilled/open symbols in all plots (see text for discussion). Intermediate (B) axes (black X's) form a girdle that is broadly coincident with the distribution of P-axes, implying that the P- and B-axes may have been subequal and flipped positions through time, a relationship that is more consistent with transtension rather than orthogonal extension. The pseudo fault plane solution (bottom right) displays a sub-vertical contractional strain axis (P-axis) and a horizontal maximum extensional strain axis (T-axis) oriented towards azimuth 067, indicating that kinematic data are consistent with ENE-WSW-directed extension or dextral transtension during the late Miocene. Because these minor faults have moderate to steep inclinations typical of newly initiated faults (Fig. 12B), they likely have not been involved in the tilting of faults and strata by $\sim 40-50^{\circ}$ across the study area (Fig. 12A). Thus, these fault kinematic data are interpreted to reflect transtensional strain after major extension in the Sierra Bacha.

Figure 16. Examples of tilt-corrected paleomagnetic results from the five paleomagnetic drill sites in the Sierra Bacha (see Figs. 4, 17 for locations). For each site, vector-component Zijderveld diagrams (left) display vector orientations for all natural remanent magnetization (NRM), low-temperature (LT), and alternating field (AF) partial demagnetization steps (in Gauss units) conducted. Partial demagnetization steps are shown for only one example core at each paleomagnetic site. $\mathrm{J} / \mathrm{J}_{0}$ plot is shown for same example core (center in $\mathrm{A}, \mathrm{B}$; top-right in $\mathrm{C}, \mathrm{D}$, $\mathrm{E})$. Right (A, B) or bottom-right $(\mathrm{C}-\mathrm{E})$ plots shows the best-fit lines and the site mean characteristic remnant magnetization $(\mathrm{ChRM})$ vectors calculated using $\mathrm{N} / \mathrm{N}_{0}$ cores collected. Site mean vectors (yellow star) and $\alpha-95$ confidence cone (red ellipse) are shown along with the expected remanence vector based on the reference paleopole for each site (green hexagon; green ellipse is $\alpha-95$ confidence cone). All analyses were conducted with PaleoMag v3.1b2 (Jones, 2002).

Figure 17. Paleomagnetic data and vertical-axis block rotations calculated for sites in the Sierra Bacha (see Table 3). (A) Paleomagnetic site locations and magnitudes of vertical-axis rotation (see Fig. 4 for explanation of map units and symbols). Rotation cannot be calculated for drill site DS-17 (Ttsi) because the tuff recorded a unique magnetic signature, likely during a field reversal or excursion, and there is no suitable stable reference site for this tuff (see text for discussion). All other sites show unresolvable rotation within standard error limits, except for DS-21 which shows $\sim 25^{\circ}$ of clockwise vertical-axis rotation near El Desemboque in the southwest. (B) Plot of vertical-axis block rotation vs. distance from modern shoreline. These results demonstrate that most of the Sierra Bacha area, especially northeast of the Bacha fault, did not experience significant dextral shear in the form of clockwise block rotations since the middle to late Miocene. CCW - counter-clockwise; CW - clockwise. 
Figure 18. Palinspastic reconstructions of the Pacific-North America plate boundary and our modified 'progressive localization' kinematic model for the northern proto-Gulf of California ca. 12-6 Ma. Reconstruction is based on the sequential restoration of documented strain from all available published geologic and geophysical datasets, including rotation of the undeformed Baja California microplate about the Pacific-North America Euler pole (see Bennett et al., 2013b for details of reconstruction methods). Segments of the modern Gulf shoreline (blue lines) are shown for reference. Areas that are either concealed beneath Quaternary alluvium or located offshore at present are shown in gray. Coordinate system (Lat/Lon) is relative to modern-day stable North America including the Sierra Madre Occidental (SMO) and remains fixed in all panels. NE- to Edirected extension occurred between ca. 12 and $9 \mathrm{Ma}$ in the Sierra Bacha and throughout coastal Sonora. Between ca. 9 and $7 \mathrm{Ma}$, the dextral component of plate motion began to progressively localize within North America, east of the Baja California microplate, coincident with an increase in the obliquity of Pacific-North America relative motion. By ca. 7 Ma, significant dextral shear was accommodated across the Gulf of California shear zone (GCSZ) via a series of en-echelon, right-stepping dextral shear zones linked by normal and oblique-normal faults. By ca. $6 \mathrm{Ma}$, strain evolved into more focused, shear-dominated transtension in the GCSZ, leading to earliest marine incursion and Pacific-North America plate boundary localization into the nascent Gulf of California at ca. 6.3 Ma. A useful analog for the late Miocene GCSZ is the modern northern Walker Lane in western Nevada (bottom right), a dextral transtensional belt embedded between the stable Sierra Nevada block and Basin and Range. Walker Lane faults are from Faulds and Henry (2009) and Gold et al. (2014). CS - Carson Sink; G - Guaymas; H Hermosillo; HL - Honey Lake; IAG - Isla Angel de la Guardia; IT - Isla Tiburón; LT - Lake Tahoe; PL - Puerto Libertad; PVP - Puertocitos Volcanic Province; PyL - Pyramid Lake; R Reno; SB - Sierra Bachoco; SeA - Sierra el Aguaje; SF - San Felipe; SL - Sierra Libre; SLP Sierra Las Pintas; SMO - Sierra Madre Occidental; SSF - Sierra San Felipe; SSR - Sierra Santa Rosa; SSU - Sierra Santa Ursula; WL - Walker Lake; Af - Amado fault; Bf - Bacha fault; DMf - De Mar fault; If - Infernillo fault; LCf - La Cruz fault; Lf - Libertad fault; Sef - Seri fault; Sf - Sacrificio fault; TT - Tiburón Transform. 
TABLE 1. GEOCHRONOLOGIC DATA FOR VOLCANIC UNITS IN THE SIERRA BACHA, COASTAL SONORA, MÉXICO.

\begin{tabular}{|c|c|c|c|c|c|c|c|c|c|c|}
\hline $\begin{array}{l}\text { Stratigraphic } \\
\text { Group }\end{array}$ & $\begin{array}{l}\text { Sample } \\
\text { Number }\end{array}$ & Unit Name & $\begin{array}{c}\text { Lithic } \\
\text { Designator }\end{array}$ & Rock Type & Latitude $\left({ }^{\circ} \mathrm{N}\right)$ & $\begin{array}{l}\text { Longitude } \\
\left({ }^{\circ} \mathrm{W}\right)\end{array}$ & $\mathrm{Age}^{*}(\mathrm{Ma})$ & $\begin{array}{l}\text { Isotopic } \\
\text { Technique }\end{array}$ & Mineral & Reference \\
\hline $3 b$ & S2G-114 & Basalt of Arivaipa & Tba & basalt & 29.663879 & 112.376733 & $6.4 \pm 1.9$ & $\mathrm{~K}-\mathrm{Ar}$ & whole rock & $\begin{array}{c}\text { Gastil \& Krummenacher } \\
\text { (1977) }\end{array}$ \\
\hline $3 b$ & SON15-2 & Basalt of Arivaipa & Tba & basalt & 29.63346 & 112.281029 & $10.59 \pm 0.06$ & $\mathrm{Ar} / \mathrm{Ar}$ & groundmass & This study \\
\hline $3 a$ & SON10-360 & Rhyolite \#2 & $\operatorname{Tr} 2$ & rhyolite & 29.596665 & 112.341369 & $11.70 \pm 0.40$ & $\mathrm{Ar} / \mathrm{Ar}$ & sanidine & This study \\
\hline $3 a$ & SE-03-06 & Andesite \#3 & Ta3 & $\begin{array}{l}\text { basaltic- } \\
\text { andesite }\end{array}$ & 29.594498 & 112.354846 & $11.76 \pm 0.16$ & $\operatorname{Ar} / \mathrm{Ar}$ & glass matrix & This study \\
\hline 3a & SON10-363 & Dacite \#2 & $\mathrm{Td} 2$ & dacite & 29.584132 & 112.308651 & $13.41 \pm 0.37$ & $\mathrm{U}-\mathrm{Pb}$ & zircon & This study \\
\hline 2 & S2G-114A & Tuff of San Ignacio & Ttsi & $\begin{array}{l}\text { rhyolite ash- } \\
\text { flow tuff }\end{array}$ & 29.513669 & 112.311228 & $10.4 \pm 0.2$ & $\mathrm{~K}-\mathrm{Ar}$ & feldspar & $\begin{array}{c}\text { Gastil \& Krummenacher } \\
\text { (1977) }\end{array}$ \\
\hline 2 & SON10-348 & Tuff of San Ignacio & Ttsi & $\begin{array}{l}\text { rhyolite ash- } \\
\text { flow tuff }\end{array}$ & 29.513881 & 112.311316 & $12.63 \pm 0.03$ & $\mathrm{Ar} / \mathrm{Ar}$ & sanidine & This study \\
\hline 2 & SON10-346 & Tuff of San Ignacio & Ttsi & $\begin{array}{l}\text { rhyolite ash- } \\
\text { flow tuff }\end{array}$ & 29.583786 & 112.317216 & $12.57 \pm 0.10$ & $\mathrm{U}-\mathrm{Pb}$ & zircon & This study \\
\hline 2 & SON10-356 & Tuff of Cerro Colorado & Ttc & $\begin{array}{l}\text { rhyolite ash- } \\
\text { flow tuff }\end{array}$ & 29.563326 & 112.294510 & $14.20 \pm 1.60$ & $\mathrm{U}-\mathrm{Pb}$ & zircon & This study \\
\hline
\end{tabular}

* Age uncertainties are reported at $2 \sigma$ for all Ar/Ar and U-Pb samples; uncertainties for K-Ar ages (Gastil and Krummenacher, 1977) are unclear. 
TABLE 2. XRF MAJOR- AND TRACE-ELEMENT GEOCHEMICAL DATA FOR VOLCANIC ROCKS IN THE SIERRA BACHA, COASTAL SONORA, MÉXICO.

\begin{tabular}{|c|c|c|c|c|c|c|c|c|c|c|c|c|c|c|c|c|c|c|c|c|}
\hline \multirow[b]{2}{*}{ Sample ID } & \multirow[b]{2}{*}{ Latitude $\left({ }^{\circ} \mathrm{N}\right)$} & \multirow[b]{2}{*}{ Longitude $\left({ }^{\circ} \mathrm{W}\right)$} & \multirow[b]{2}{*}{$\mathrm{Age}^{\dagger}(\mathrm{Ma})$} & \multirow[b]{2}{*}{ Group } & \multirow[b]{2}{*}{ Unit } & \multicolumn{11}{|c|}{ wt $\%$} & \multirow[b]{2}{*}{ LOI (\%) } & \multicolumn{3}{|c|}{$\mathrm{ppm}$} \\
\hline & & & & & & $\mathrm{SiO}_{2}$ & $\mathrm{TiO}_{2}$ & $\mathrm{Al}_{2} \mathrm{O}_{3}$ & $\mathrm{Fe}_{2} \mathrm{O}_{3}$ & $\mathrm{MnO}$ & $\mathrm{MgO}$ & $\mathrm{CaO}$ & $\mathrm{Na}_{2} \mathrm{O}$ & $\mathrm{K}_{2} \mathrm{O}$ & $\mathrm{P}_{2} \mathrm{O}_{5}$ & Totals & & $\mathrm{Rb}$ & $\mathrm{Sr}$ & $\mathrm{Zr}$ \\
\hline SON11-124 & 29.648939 & 112.400812 & $<12.6$ & 3а & Ttp & 66.36 & 0.35 & 15.32 & 2.89 & 0.06 & 0.93 & 2.73 & 4.79 & 3.65 & 0.11 & 97.19 & 2.58 & 97 & 471 & 333 \\
\hline SON11-99 & 29.580402 & 112.301645 & $11.7 \pm 0.4$ & $3 a$ & $\operatorname{Tr} 2$ & 71.14 & 0.24 & 12.97 & 3.78 & 0.07 & 0.01 & 0.37 & 5.27 & 4.89 & 0.04 & 98.78 & 1.06 & 135 & 16 & 980 \\
\hline SON10-273 & 29.597511 & 112.335371 & $12.6-11.7$ & 3a & $\mathrm{Td} 3$ & 66.88 & 0.28 & 14.75 & 3.93 & 0.12 & 0.26 & 1.7 & 5.95 & 4 & 0.08 & 97.95 & 1.75 & 93 & 144 & 513 \\
\hline SON10-127 & 29.583123 & 112.314946 & $12.6-11.8$ & $3 a$ & Td1 & 60.75 & 0.98 & 16.11 & 6.49 & 0.11 & 1.71 & 2.86 & 5.85 & 3.19 & 0.41 & 98.46 & 1.35 & 68 & 328 & 468 \\
\hline SON11-73B & 29.549143 & 112.371589 & 12.6 & 2 & Ttsf & 69.8 & 0.14 & 11.86 & 1.86 & 0.05 & 0.32 & 3.97 & 3.53 & 4.61 & 0.05 & 96.19 & 3.7 & 180 & 44 & 410 \\
\hline SON10-346 & 29.583795 & 112.317195 & 12.6 & 2 & Ttsi & 70.56 & 0.21 & 13.58 & 2.53 & 0.06 & 0.37 & 0.94 & 4.06 & 5.71 & 0.08 & 98.1 & 1.78 & 220 & 44 & 447 \\
\hline SON11-83A & 29.651741 & 112.275164 & 12.6 & 2 & Ttsii $^{*}$ & 69.93 & 0.2 & 13.6 & 2.24 & 0.03 & 0.17 & 0.88 & 1.41 & 8.65 & 0.06 & 97.17 & 2.66 & 326 & 96 & 242 \\
\hline SON11-46 & 29.639681 & 112.463425 & $>12.6$ & 2 & Tdf & 65.01 & 0.54 & 15.63 & 3.91 & 0.06 & 1.39 & 3.71 & 4.33 & 2.54 & 0.3 & 97.42 & 2.32 & 61 & 599 & 309 \\
\hline SON10-46 & 29.560326 & 112.292139 & $14.2-12.6$ & 2 & Ta2 & 55.94 & 1.43 & 17.18 & 7.67 & 0.11 & 3.02 & 5.91 & 4.75 & 1.83 & 0.34 & 98.18 & 1.61 & 40 & 673 & 249 \\
\hline SON10-358 & 29.565107 & 112.300638 & $>14.2$ & 2 & Ta1 & 51.78 & 2.29 & 16.16 & 10.98 & 0.17 & 3.95 & 6.63 & 4.68 & 1.54 & 0.43 & 98.61 & 1.22 & 23 & 501 & 285 \\
\hline
\end{tabular}

* Rheomorphic Ttsi labeled "R" in Figure 6

${ }^{\dagger}$ Aaes based on stratiaraphic relationships (Fia. 5) and aeochronoloaic data (Table 1) from this studv. 
TABLE 3. PALEOMAGNETIC DATA AND ROTATION CALCULATIONS FOR DRILL SITES IN THE SIERRA BACHA, COASTAL SONORA, MEXICO.

\begin{tabular}{|c|c|c|c|c|c|c|c|c|c|c|c|c|c|c|c|c|c|c|c|c|c|c|}
\hline \multirow[b]{2}{*}{ Drill Site } & \multirow[b]{2}{*}{ Unit* } & \multirow[b]{2}{*}{$\begin{array}{l}\text { Age } \\
\text { (Ma) }\end{array}$} & \multirow[b]{2}{*}{$\begin{array}{l}\text { Latitude } \\
\left({ }^{\circ} \mathrm{N}\right)\end{array}$} & \multirow[b]{2}{*}{$\begin{array}{l}\text { Longitude } \\
\text { ('W) }\end{array}$} & \multicolumn{2}{|c|}{ Bedding $^{\dagger}$} & \multirow[b]{2}{*}{$\mathrm{N} / \mathrm{N}_{0}$} & \multirow[b]{2}{*}{ Corr. factor } & \multicolumn{2}{|c|}{ Geographic } & \multicolumn{2}{|c|}{$\begin{array}{l}\text { Tilt corrected } \\
\end{array}$} & \multicolumn{2}{|c|}{$\begin{array}{l}\text { Fisher statistics } \\
\end{array}$} & \multicolumn{4}{|c|}{ TFilt corrected Bingham statistics } & \multicolumn{2}{|c|}{ Rotation } & \multicolumn{2}{|c|}{ Flattening } \\
\hline & & & & & $\overline{\text { Strike }\left({ }^{\circ}\right)}$ & $\begin{array}{l}\text { Dip } \\
\left({ }^{\circ}\right) \\
\end{array}$ & & & $\begin{array}{c}\text { Dec } \\
\left({ }^{\circ}\right)\end{array}$ & $\begin{array}{l}\operatorname{lnc} \\
\left({ }^{\circ}\right) \\
\end{array}$ & $\begin{array}{c}\text { Dec } \\
\left({ }^{\circ}\right)\end{array}$ & $\begin{array}{l}\text { Inc } \\
\left({ }^{\circ}\right) \\
\end{array}$ & $\begin{array}{c}\alpha 95 \\
\left(^{\circ}\right) \\
\end{array}$ & к & $\mathrm{K}_{1}$ & $\begin{array}{c}\alpha 95 \\
\left({ }^{\circ}\right)\end{array}$ & $\mathrm{K}_{2}$ & $\begin{array}{c}\alpha 95 \\
\left({ }^{\circ}\right)\end{array}$ & $\begin{array}{l}R^{\sigma} \\
\left({ }^{\circ}\right) \\
\end{array}$ & $\begin{array}{c}\Delta \mathrm{R}^{\psi} \\
\left(^{\circ}\right)\end{array}$ & $\begin{array}{l}\text { Fó } \\
\left({ }^{\circ}\right) \\
\end{array}$ & $\begin{array}{c}\Delta \mathrm{F}^{\psi} \\
\left({ }^{\circ}\right) \\
\end{array}$ \\
\hline DS-17 & Ttsi & $\sim 12.6$ & 29.582660 & 112.316148 & 308 & 40 & $12 / 12$ & 0.79 & 231.6 & -40.5 & 228.3 & -1.3 & 1.48 & 907.82 & -851.03 & 1.03 & -6.68 & 12.16 & ND & ND & ND & ND \\
\hline DS-21 & Ttsf & $\sim 12.6$ & 29.548521 & 112.371580 & 359 & 55 & $19 / 19$ & 0.79 & 223.7 & -39.4 & 235.5 & 4.7 & 2.6 & 181.34 & -16.82 & 5.89 & -0.27 & 6.37 & 25.4 & 2.4 & -7.7 & 2.4 \\
\hline DS-22 & Ttc & $14.2 \pm 1.6$ & 29.581697 & 112.348191 & 312 & 48 & $11 / 12$ & 0.79 & 326.9 & 49.2 & 358.9 & 22.4 & 9.25 & 29.88 & -29.37 & 6.76 & -1.72 & 36.78 & -3.1 & 11.1 & 26.6 & 10.7 \\
\hline DS-23 & Tr2 & $11.7 \pm 0.4$ & 29.580733 & 112.301918 & 295 & 52 & $5 / 6$ & 0.77 & 320.1 & 58.8 & 355 & 20.7 & 4.5 & 229.46 & -21312 & 0.3 & -90.33 & 4.69 & -7 & 8.5 & 28.3 & 8.3 \\
\hline DS-24 & Tba & $10.6 \pm 0.1$ & 29.635678 & 112.274311 & 221 & 1 & $12 / 12$ & 0.79 & 4.2 & 39.9 & 3.5 & 39.4 & 4.3 & 125.42 & -54.07 & 4.15 & -0.33 & 4.53 & 1.5 & 9.0 & 9.6 & 8.5 \\
\hline
\end{tabular}

Note: $\mathrm{N} / \mathrm{N}_{0}$ - number of samples used to determine site-mean direction/number of samples collected. Correction factor based on value of $\mathrm{N}$ used in calculation of $\Delta R, \Delta \mathrm{F}$ (Demarest, 1983). Dec - declination in degrees; Inc -

inclination in degrees; $\alpha 95$ - cone of $95 \%$ confidence about site-mean direction; $\mathrm{K}$ - precision parameter (Fisher, 1953). Values for declination have been corrected to geographic north using an $11^{\circ}$ magnetic declination for the study

* See text and/or Darin and Dorsey (2014) for unit names and descriptions

Bedding orientation used for structural correction; dip direction is $90^{\circ}$ clockwise from strike according to the right-hand rule

${ }^{\circ} \mathrm{R}$ - Rotation in degrees (clockwise = positive); F - Flattening in degrees (down from horizontal = positive). DS-21 ( Ttsf) calculated relative to Tuff of San Felipe stable reference site in Baja California (Bennett and Oskin, 2014); $2.3^{\circ}$ has been added to $\mathrm{R}$ for this site to account for finite rotation of reference site due to Pacific-North America plate motion. Rotation at sites DS-22, DS-23, and DS-24 are calculated relative to the average Miocene paleopole for North America at the latitude of the study area (see text for details).

${ }^{4} \Delta R-95 \%$ confidence limits on rotation; $\Delta \mathrm{F}-95 \%$ confidence limits on flattening. Both calculated according to Beck (1980) and Demarest (1983) 


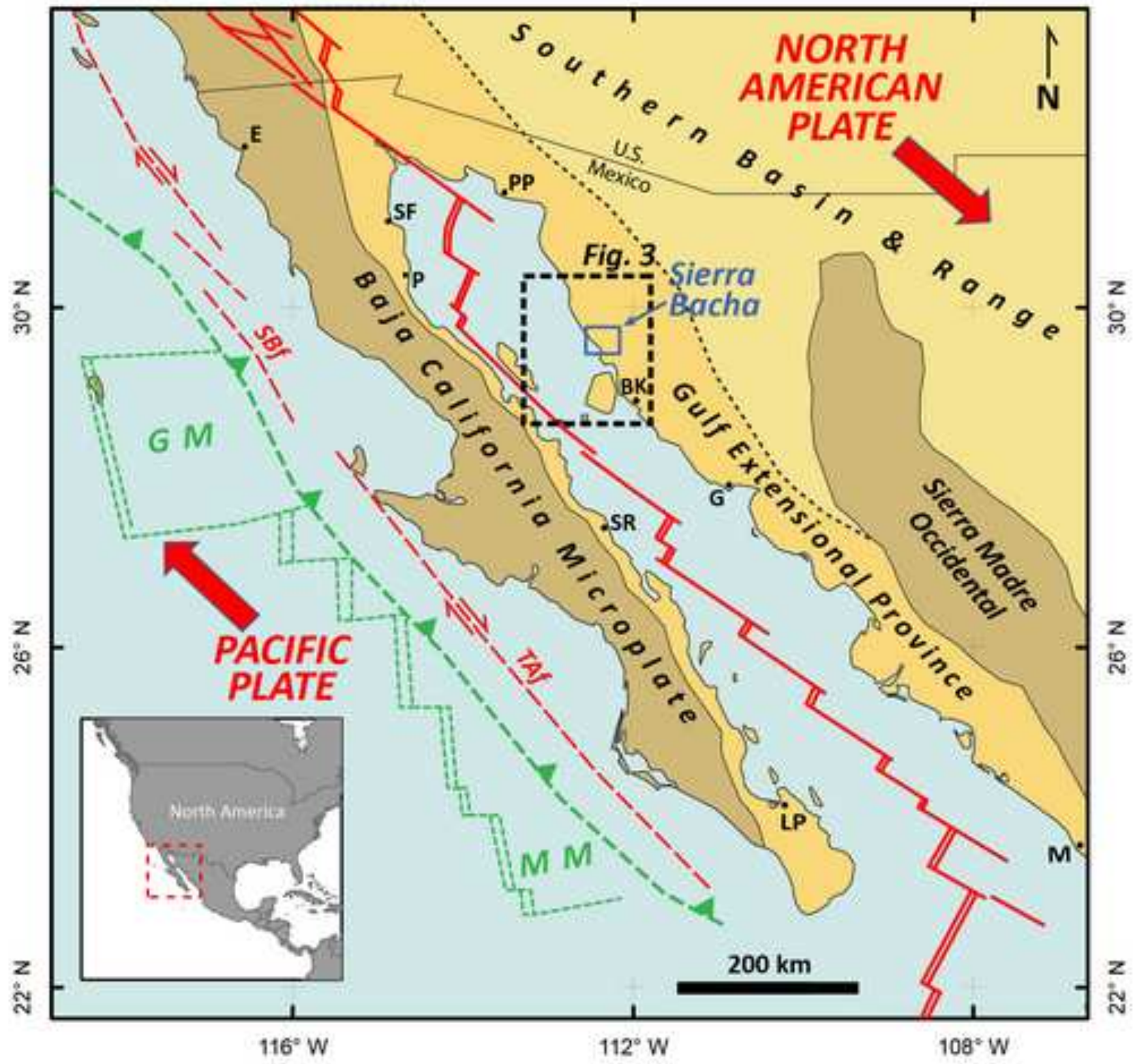

Figure 1. Regional tectonic map of the Pacific-North America plate boundary in northwestern México and the southwestern United States. Green dashed lines represent inactive plate boundaries, including the former trench related to Farallon-North America subduction and stalled Pacific-Farallon spreading ridges and related microplates. Subduction of the Farallon plate and related microplates ended by ca. $12.5-12 \mathrm{Ma}$, leading to plate boundary reorganization from ca. 12.5 to $6 \mathrm{Ma}$. Solid red lines indicate the modern plate boundary, which accommodates modern oblique rifting and opening of the Gulf of California. Abbreviations: BK - Bahia Kino, E - Ensenada, G - Guaymas, GM - Guadalupe microplate; LP - La Paz, M - Mazatlan, MM - Magdalena microplate; P - Puertecitos, PP - Puerto Peñasco, SF - San Felipe, SR Santa Rosalía, SBf - San Benito fault, TAf - Tosco-Abreojos fault. 


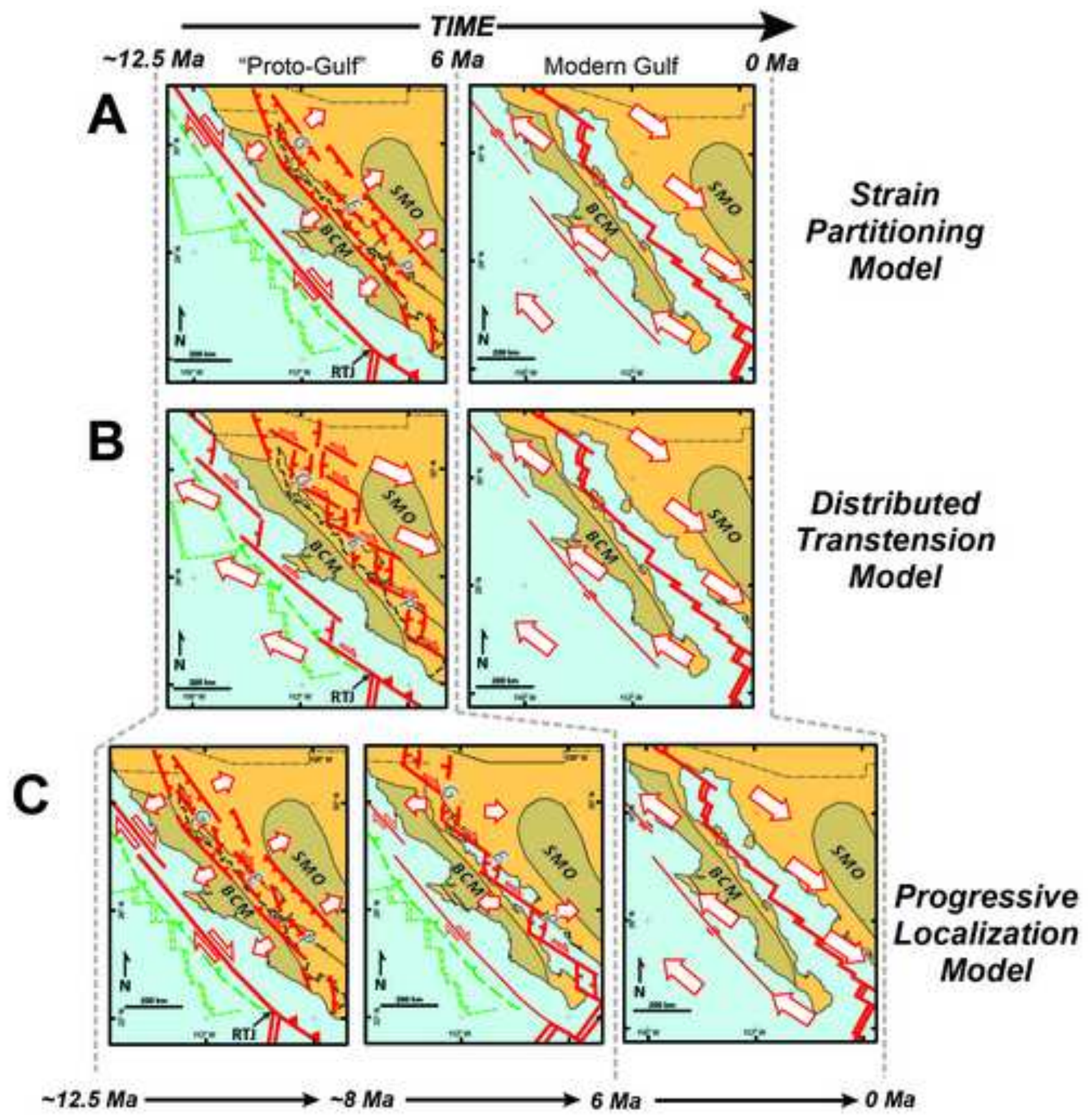

Figure 2. Alternative kinematic models for the timing and distribution of extension and dextral shear related to evolution of the Gulf of California since $\mathrm{ca}$. $12.5 \mathrm{Ma}$. Active faults during each time period are shown in red. Darker colored regions are relatively undeformed. The ca. pre-12.5 Ma subduction boundary is dashed in green. BCM - Baja California microplate; GEP - Gulf Extensional Province; RTJ - Rivera Triple Junction; SMO - Sierra Madre Occidental. The 6-0 Ma ("Modern Gulf") panel is the same in each model: transtension since ca. $6 \mathrm{Ma}$ has occurred almost entirely within the oblique Gulf of California rift. (A) "Strain partitioning" model in which proto-Gulf (12.5-6 Ma) strain was partitioned between offshore dextral shear and orthogonal extension in the Gulf Extensional Province (GEP; Stock and Hodges, 1989). (B) "Distributed transtension" model which proposes a single stage of diffuse and integrated transtensional strain from offshore west of Baja California to the interior of the North American continent within the GEP since ca. $12 \mathrm{Ma}$ (Fletcher et al., 2007). (C) "Progressive localization" model (Bennett, 2009; Seiler et al., 2011; Bennett et al., 2013a; Bennett and Oskin, 2014; this study) in which early proto-Gulf strain (ca. 12.5-9 Ma) was partitioned according to the strain partitioning model, followed by the progressive localization of dextral shear into the proto-Gulf of California during latest Miocene time $(-9-6 \mathrm{Ma})$. 


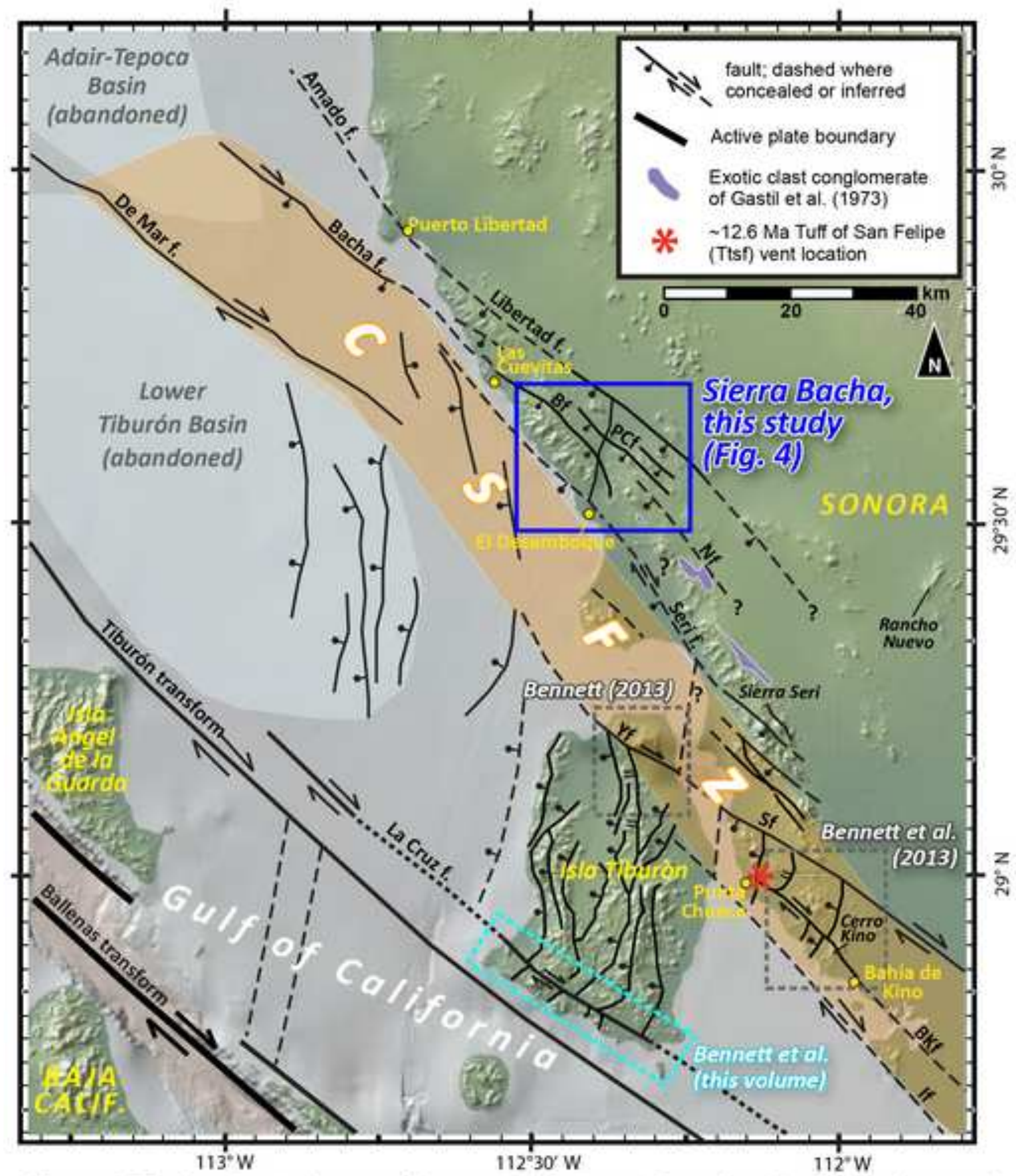

Figure 3. Regional tectonic map of the coastal Sonora study region showing onshore and offshore rift-related structures and basins. Faults are from Oskin (2002), Aragón-Arreola and Martin-Barajas (2007), Mar-Hernandez et al. (2012); Bennett et al. (2013a), Martín-Barajas et al. (2013), and this study. The Coastal Sonora fault zone (CSFZ; orange) hosted a significant amount of dextral shear and clockwise block rotations during latest Miocene time (Bennett et al., 2013a). The spatial and temporal distribution of dextral shear in adjacent areas like the Sierra Bacha (blue box) has not been documented prior to this study. Bf Bacha fault, BKf - Bahia Kino fault, If - Infernillo fault, Nf - Noriega fault, PCf - Pozo Coyote fault, Sf - Sacrificio fault; Yf - Yawassag fault. 


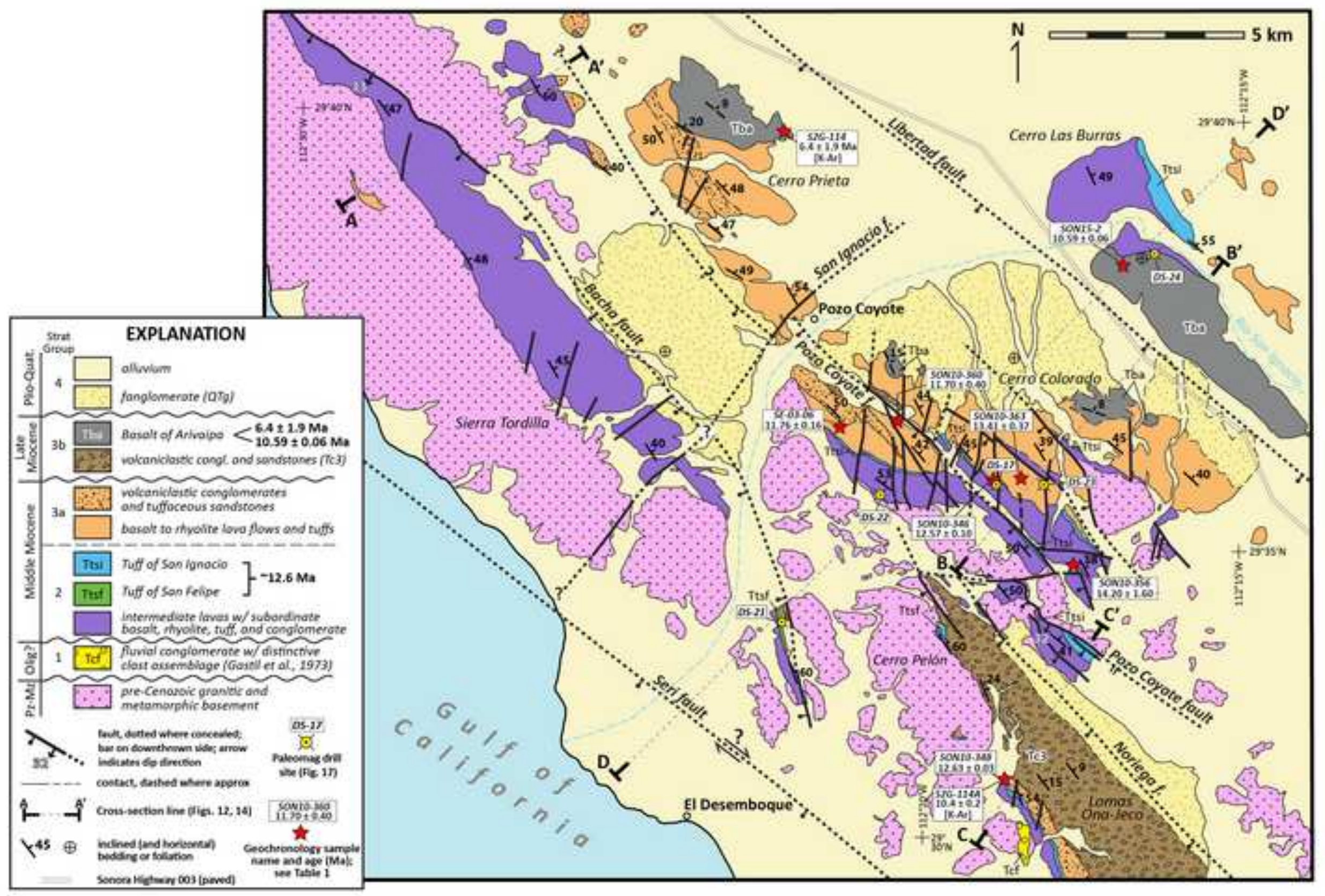

Figure 4. Simplified geologic map of the Sierra Bacha (see Figs. 1 and 3 for location). All geochronologic data are reported at the 2- $\sigma$ confidence level (see Table 1). A detailed, 1:30,000-scale version of this map is available through the Geological Society of America's Digital Map and Chart Series (Darin and Dorsey, 2014). 


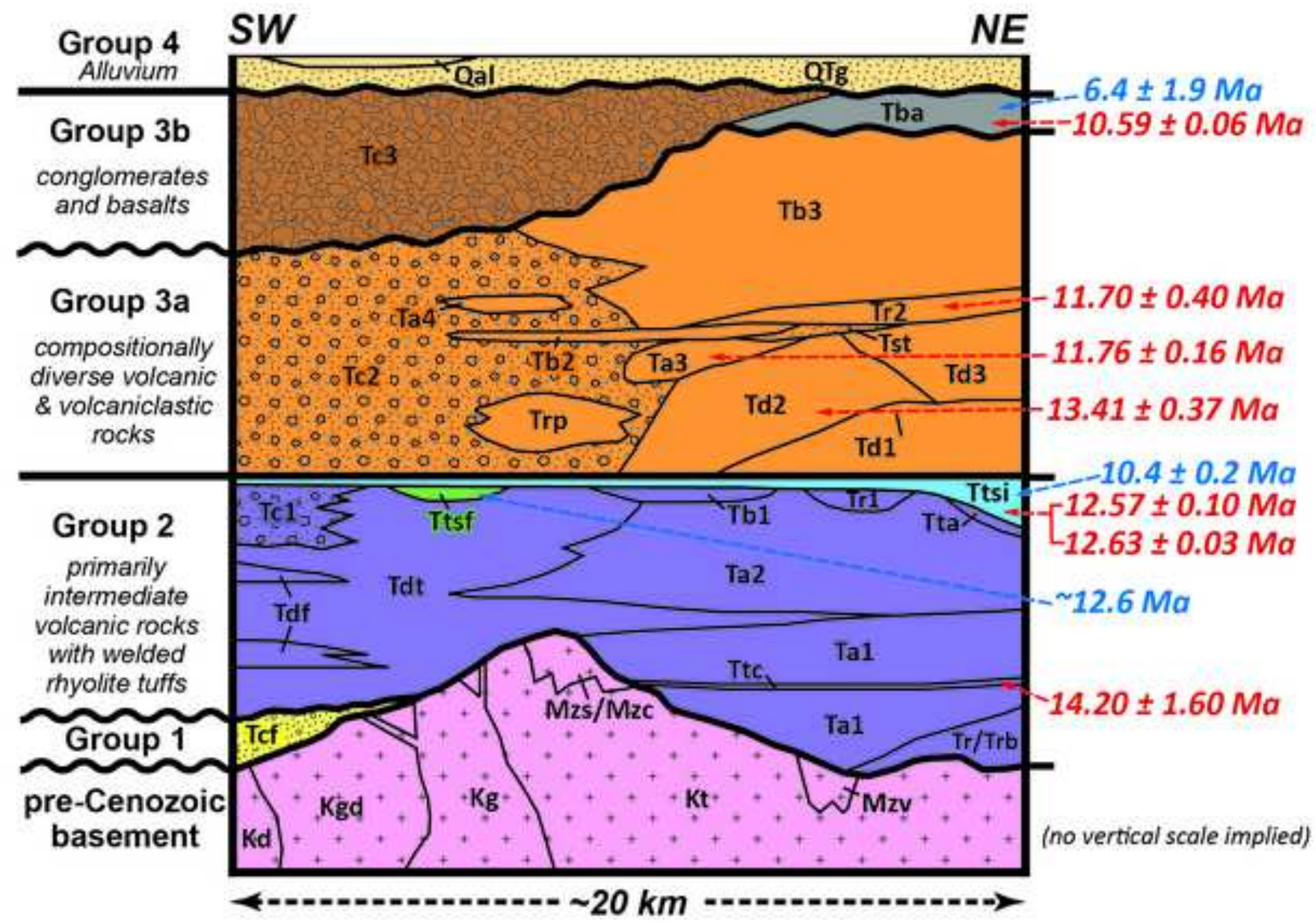

Figure 5. Schematic stratigraphic correlation chart of geologic units in the Sierra Bacha. Stratal geometries and depositional relationships are diagrammatic and not to scale. New geochronological data from this study are labeled in red (see Table 1); published ages for Ttsf (Stock et al., 1999) and Ttsi and Tba (Gastil and Krummenacher, 1977) are labeled in blue. See text for brief descriptions of key units; the reader is referred to Darin and Dorsey (2014) for map relationships and detailed descriptions of each unit. 

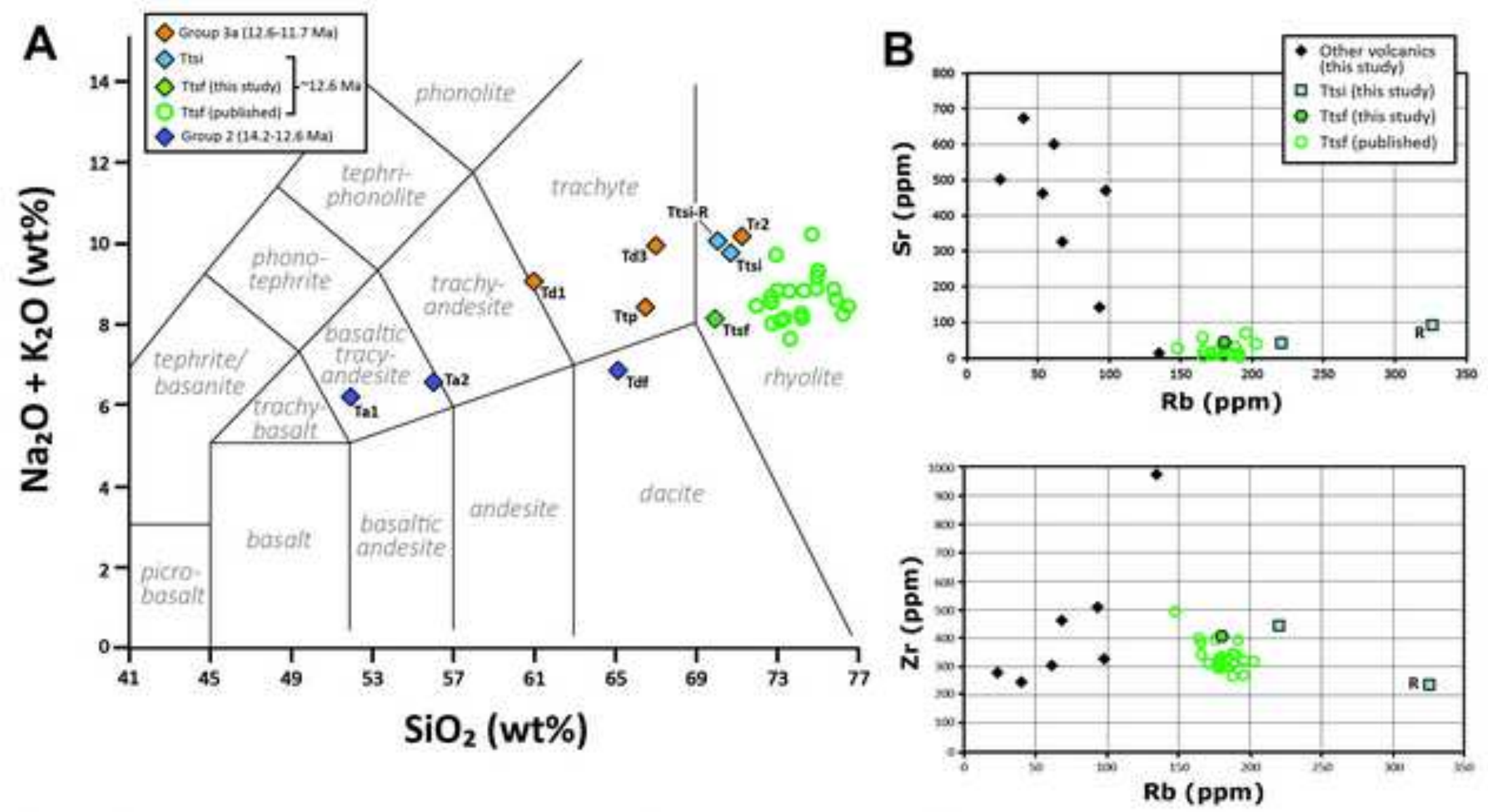

Figure 6. Bulk geochemical data for middle to late Miocene volcanic units in the Sierra Bacha (see Table 2 for XRF major- and trace-element data). (A) Total alkali versus silica diagram. All samples show high total alkali concentrations $>6 \mathrm{wt} \%$. (B) Comparison of bulk rock trace element data for the $\sim 12.6 \mathrm{Ma}$ tuffs of San Ignacio (Ttsi) and San Felipe (Ttsf). Ttsf in the Sierra Bacha (green hexagon) correlates strongly with other published geochemical data for Ttsf from Baja California and coastal Sonora (open green circles). Chemical zoning associated with meomorphism ('R') may explain variations in trace element content between the two Ttsi samples (blue squares).

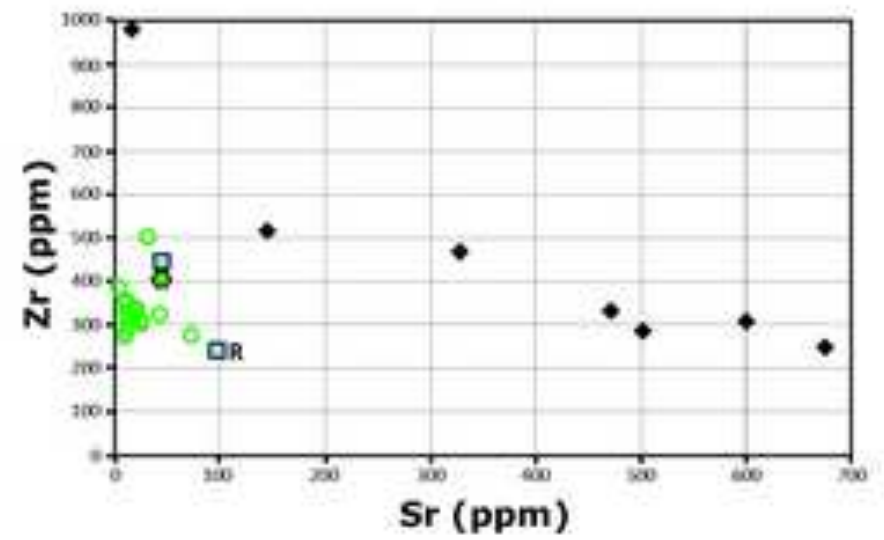


Figure 7. U-Pb geochronological ages calculated for volcanic rocks from the Sierra Bacha. (A) Tera-Wasserburg U.Pb concordia plot (left) and plot of individual ${ }^{206} \mathrm{~Pb} / 39 \mathrm{U}$ ages (right) of analyzed zircon grains for Tuff of Cerro Colorado sample SON10-356 (Ttc) located near the base of the $-2 \mathrm{~km}$ thick volcanic section at Cerro Colorado. (B) Tera-Wasserburg $\mathrm{U}-\mathrm{Pb}$ concordia plot (left) and weighted averages of individual $30 \mathrm{~Pb} / 2$ U ages (right) of analyzed zircons for Tuff of San Ignacio sample SON10-346 (Tisi). (C) Tera-Wasserburg U.Pb concordia plots (left and center) and weighted averages of individual toe $\mathrm{Pb} / 2 \times \mathrm{U}$ ages (right) of analyzed zircons for dacite sample SON10-363 (Td2), In all concordia plots, solid-line ellipses with black square centers are data used for age calculations; gray-line ellipses are data excluded from age calculations due to different degrees of Pb-loss or zircon inheritance. All mean ages are reported at 20 uncertainty level. See Supplemental Table S1 for U.Pb single-crystal zircon analytical data. MSWD - mean square of weighted deviates,
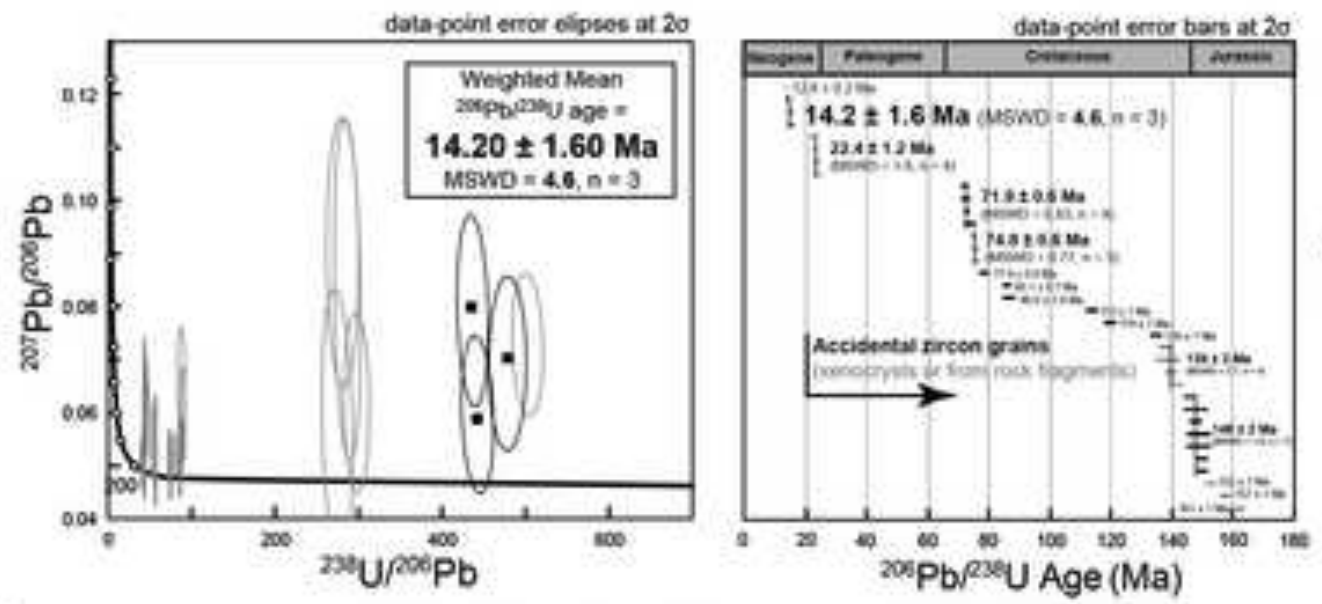

A

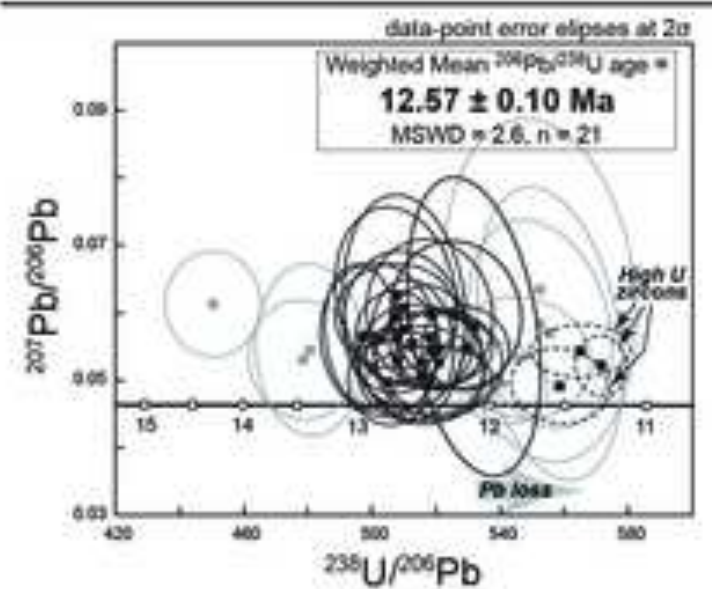

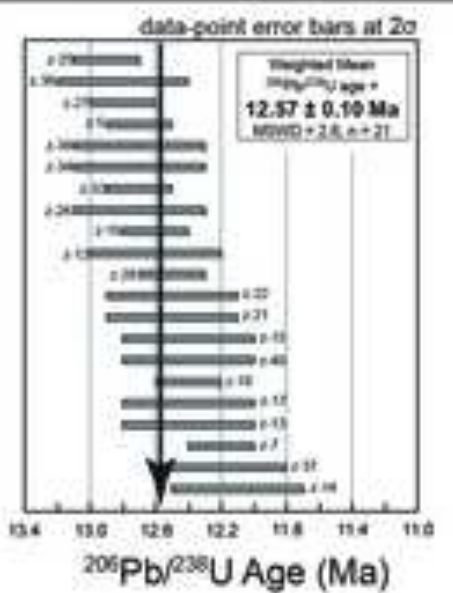

SON10-346

Tuff of San

Ignacio
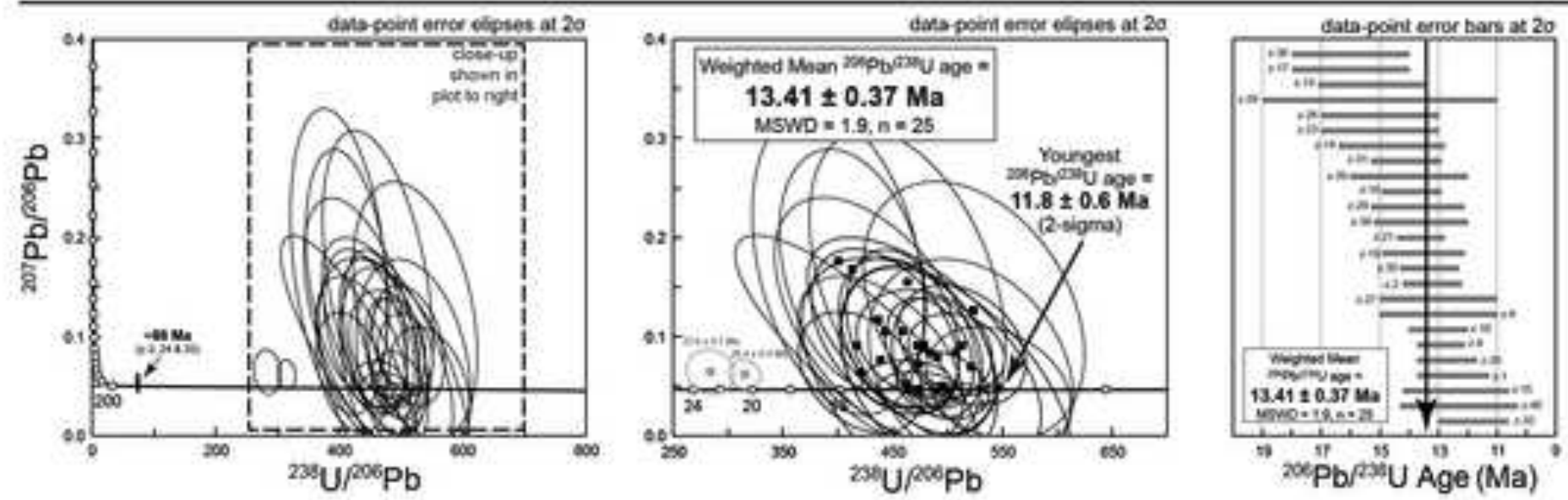

SON10-363

Dacite \#2

(Td2)

B

(Ttsi)

ON10-356

T(c)

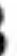

C 

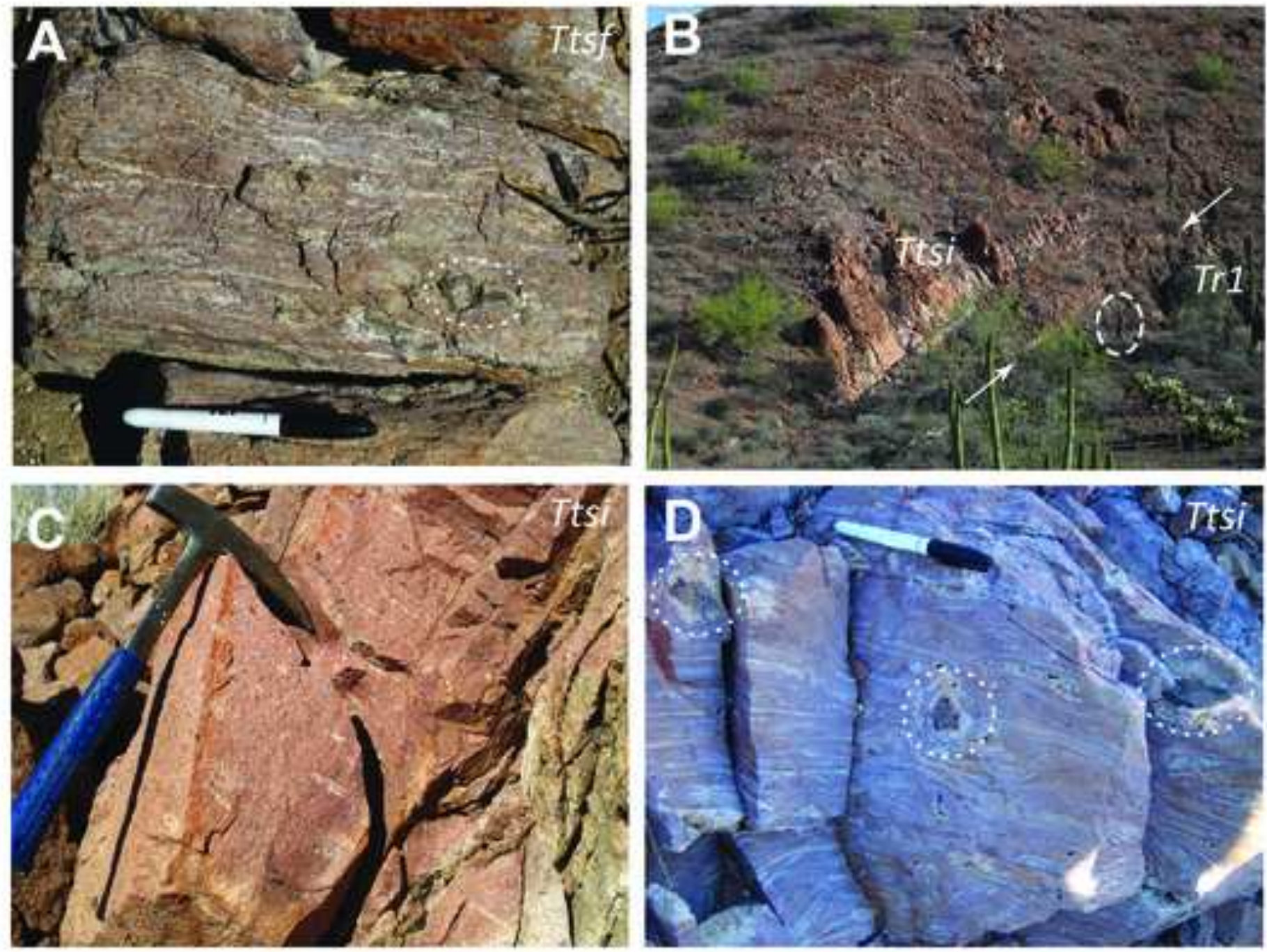

Figure 8. Field photographs of upper group $2(-12.6 \mathrm{Ma})$ ignimbrites in the Sierra Bacha. (A) Typical appearance of the Tuff of San Felipe ( $T / s)$ west of Cerro Pelón. Note eutaxitic foliation defined by flattened white pumice fiamme and a single large, glassy trachyte-rhyolite inclusion containing abundant plagioclase (dashed circle). View is looking northeast. Marker is $13.5 \mathrm{~cm}$-long for scale, (B) Looking southeast at the basal contact (arrows) of the Tuff of San Ignacio ( $T$ tsi). The densely welded facies (below "Tts/' label) forms resistant outcrops throughout the Sierra Bacha. Geologist (circled) is $-1.7 \mathrm{~m}$ tall for scale. (C) Looking northwest at the densely welded zone a few meters above the base of $T$ tsi at Cerro Colorado. Eutaxitic foliation dips moderately towards the northeast (right) and is defined by $1-3$ cm-long. white to pink, flattened pumice fiamme. Hammer is $32.5 \mathrm{~cm}-l o n g$ for scale, (D) Rheomorphic flow structures in Ttsi at Cerro Las Burras this unit is up to $300 \mathrm{~m}$-thick. Pumice are completely replaced by secondary quartz and irregularty folded and stretched up to $40 \mathrm{~cm}$ in length, Dark, vesicular trachyandesite inclusions (dashed circles) are up to $4 \mathrm{~cm}$ in diameter. View is towards the northeast. Marker is $13.5 \mathrm{~cm}$-long for scale. 
Figure (with caption below and on the same page)
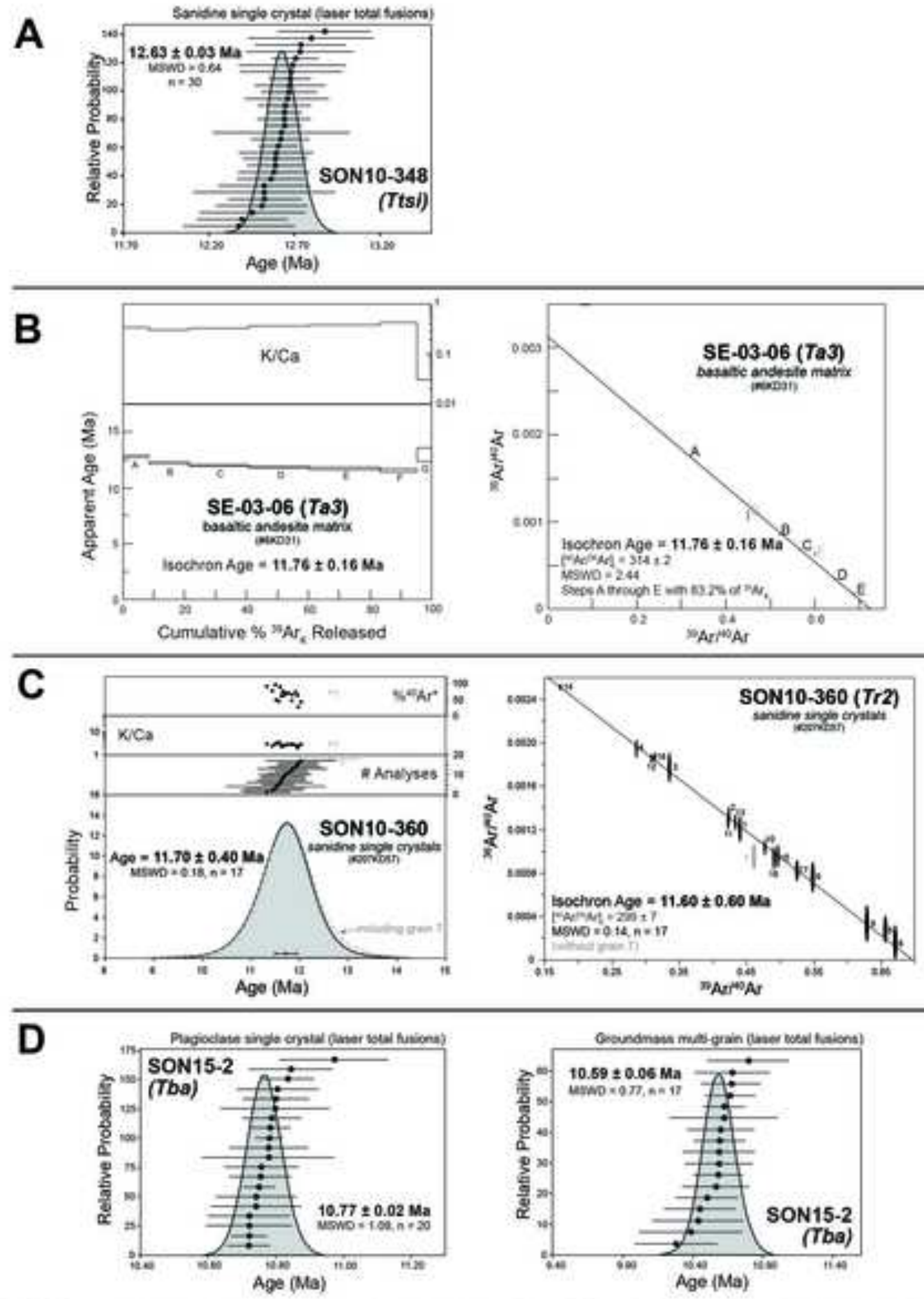

Figure 9. "AxmAr geochronologic ages calculated for volcanic rocks in the Siema Bacha. Uncertainty is reported at 20 level tor all data and graphs. (A) Age probability diagram for single crystai sanicfine laser total fusions for ignimbrite sample SON10-348 (Ttsi). (B) K/Ca ratios and age spectrum diagram (left) and inverse isochron diagram (right) for basaltic andesite sample SE-03-06 (Ta3). Gray shaded letters indicate step-heating steps excluded from the isochron age calculation. (C) Percent ${ }^{\circ} \mathrm{Ar}$ ( (radiogenic Ar), KJCa ratios, and age probability diagrams of multiple single-grain total fusion ages of sanidine crystals (lef) and inwerse isochron diagram (right) for rhyolite sample SON10-360 (Tr2), (D) Age probabilly diagram for laser total fusions on basalt sample SON15-2 (Tba), See Supplemental Tables \$2 \& S3 for ${ }^{\circ} \mathrm{Ar}$ P Ar analytical data. MSWD - mean square of weighted deviates. 

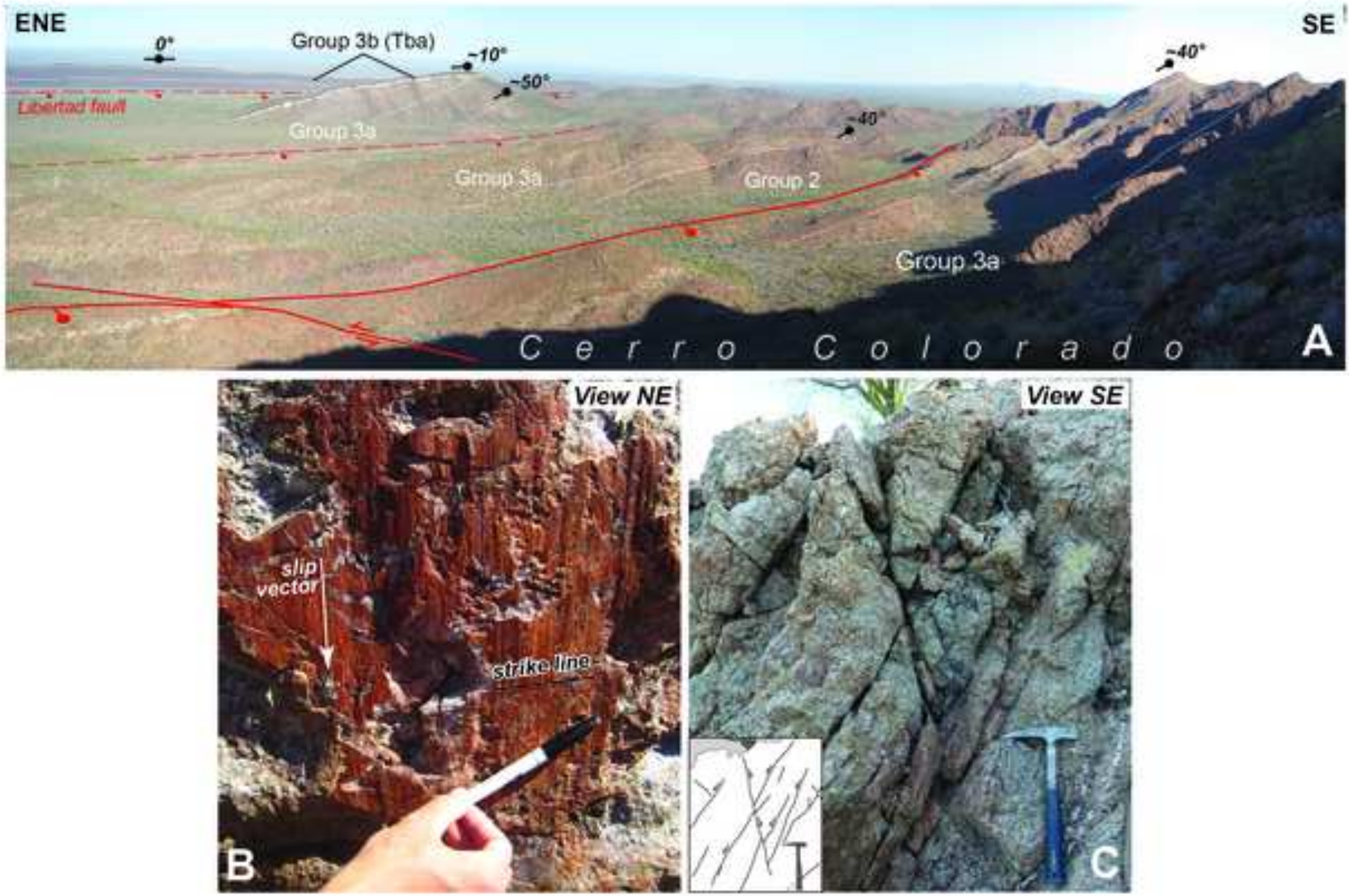

Figure 10. Field photographs showing structural features of the Sierra Bacha. (A) East-northeast to southeast-facing panorama of eastern Cerro Colorado showing faults (red), bedding form lines (dotted white), bedding attiudes (black) and the angular uncontormity between group $3 a$ and $3 b$ strata (dashed white line). Southwest-dipping normal faults tilted the entire section uniformly down-to-the-northeast between ca. 11.7 and $9.6 \mathrm{Ma}$. although the minimum age of tilting is poorly constrained farther southwest (see text for discussion). (B) Typical polished and striated fault surface in the study area. This fault cuts an upper group 2 welded tuff at Cerro Las Burras and dips steeply towards the southwest. Fault striae plunge very steeply $\left(-90^{\circ}\right)$ and small secondary fractures subparallel to fault strike indicate that the missing block (i.e., hanging wall) moved down (white arrow), indicating normal displacement for this fault. (C) NW-SE-striking. steeply-dipping conjugate faults in Late Cretaceous tonalite basement less than 4 meters from the Bacha fault (just out of view to the right/southwest). Kinematic indicators at this outcrop consistently plunge very steeply and indicate normal displacement. The orientation of these conjugate faults imply a vertical maximum principal stress, suggesting that these minor faults have not been involved in, and thus post-date, dornino-style tilting of major structures (e,g., Bacha fault) to shallower dips. 

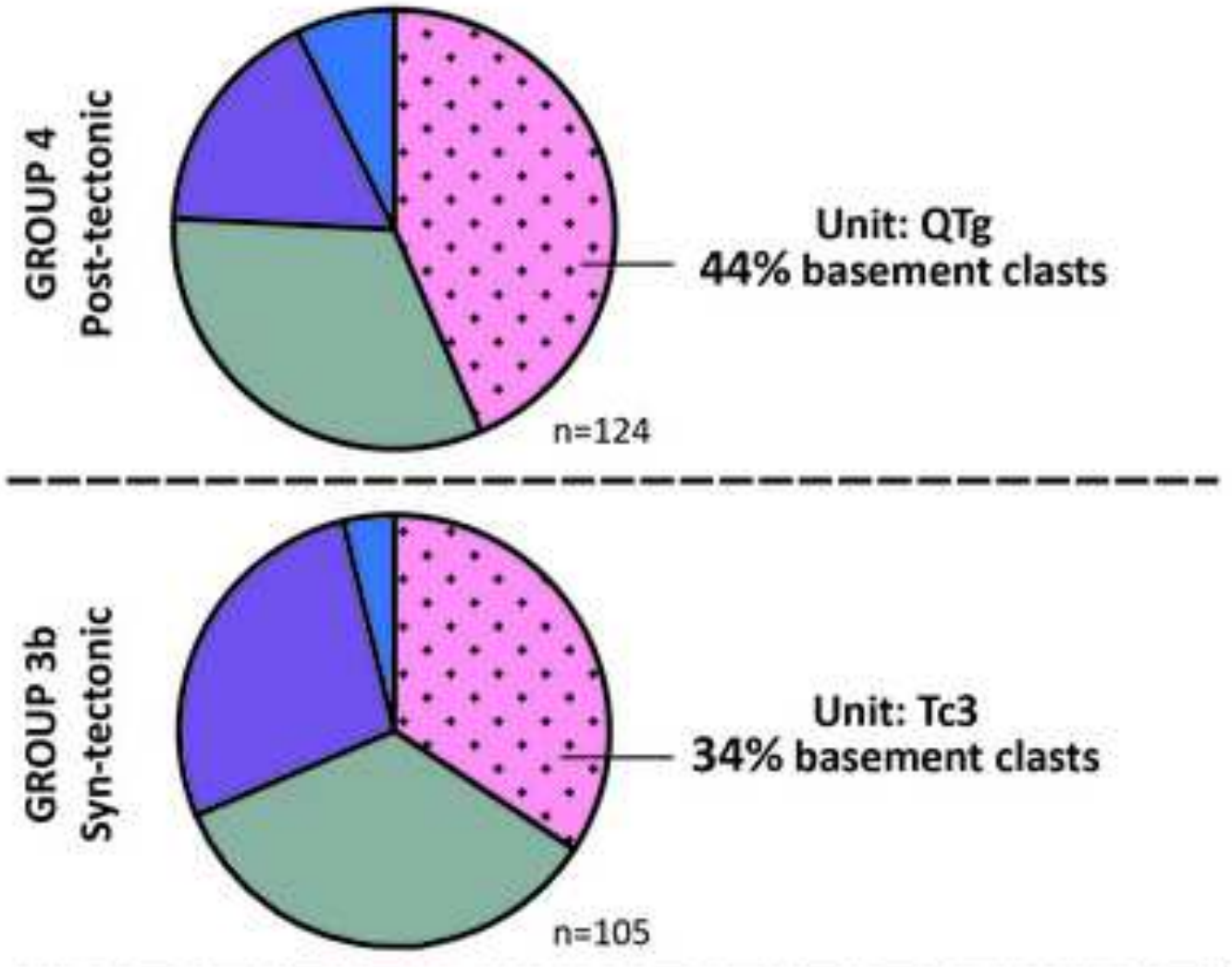

$\sim 11.7 \mathrm{Ma}$

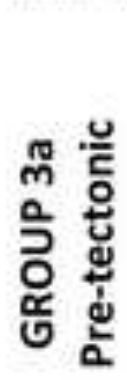

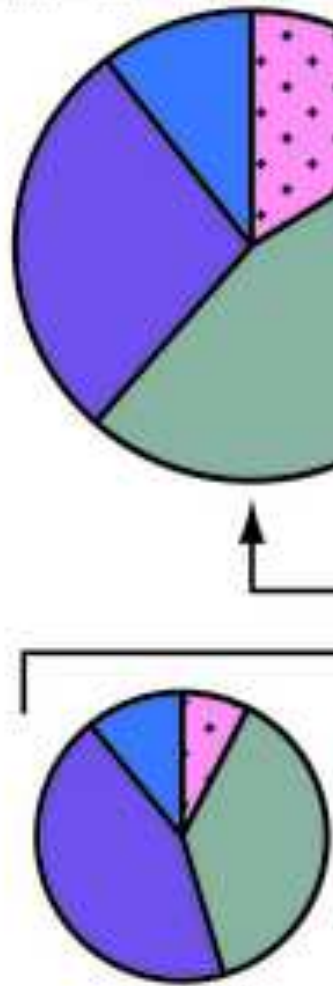

$n=119$

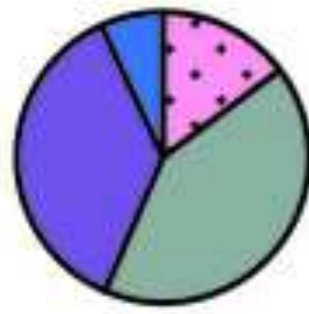

$\mathrm{n}=115$

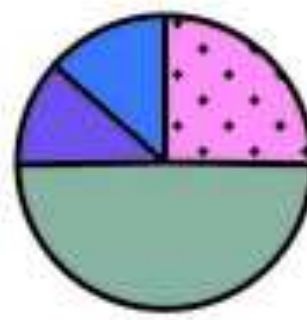

$\mathrm{n}=111$
Unit: Tc1/Tc2 $16 \%$ basement clasts undifferentiated wolcanics

dacite/rhyolite

basalt/andesite

pre-Cenozoic basement rocks

Figure 11. Clast count data for conglomerate units in the study area. Note significant increase in basement clast modal content up-section from average of $\sim 16 \%$ in pre-tectonic conglomerates to $44 \%$ in post-tectonic conglomerates. We interpret this signal to be related to tectonic

unroofing and basement exhumation during late Miocene extension.

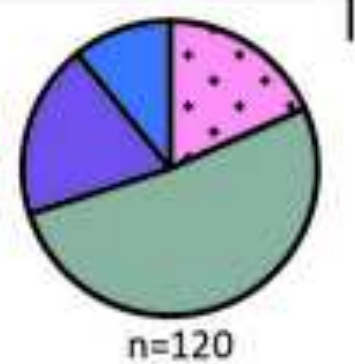




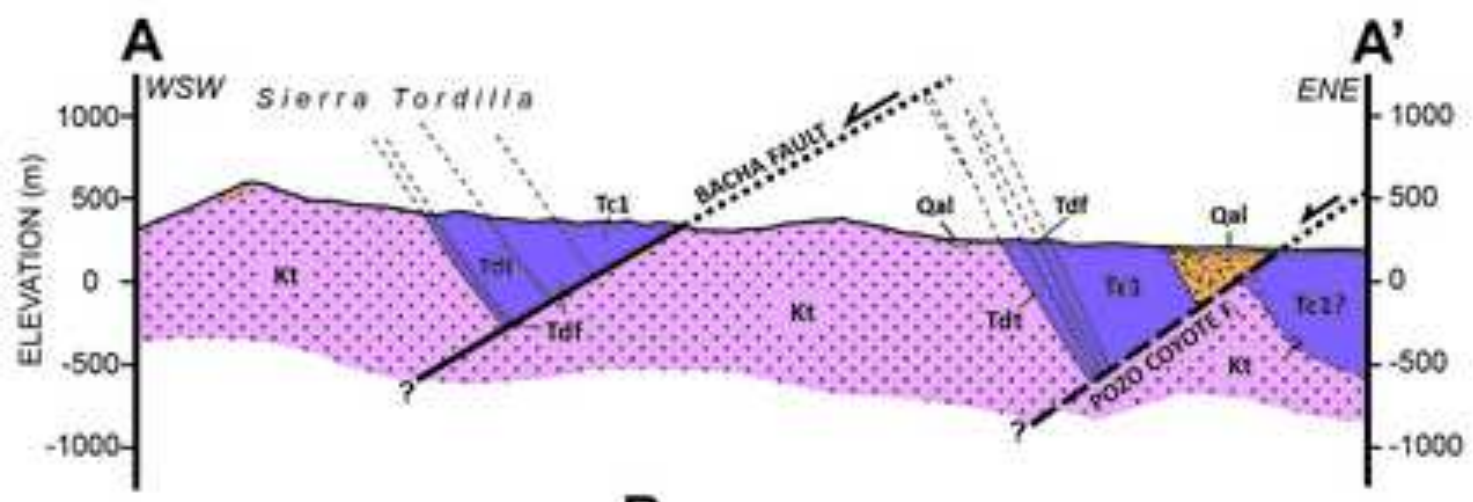

\section{*All sections are drawn to scale (no vertical exaggeration)}
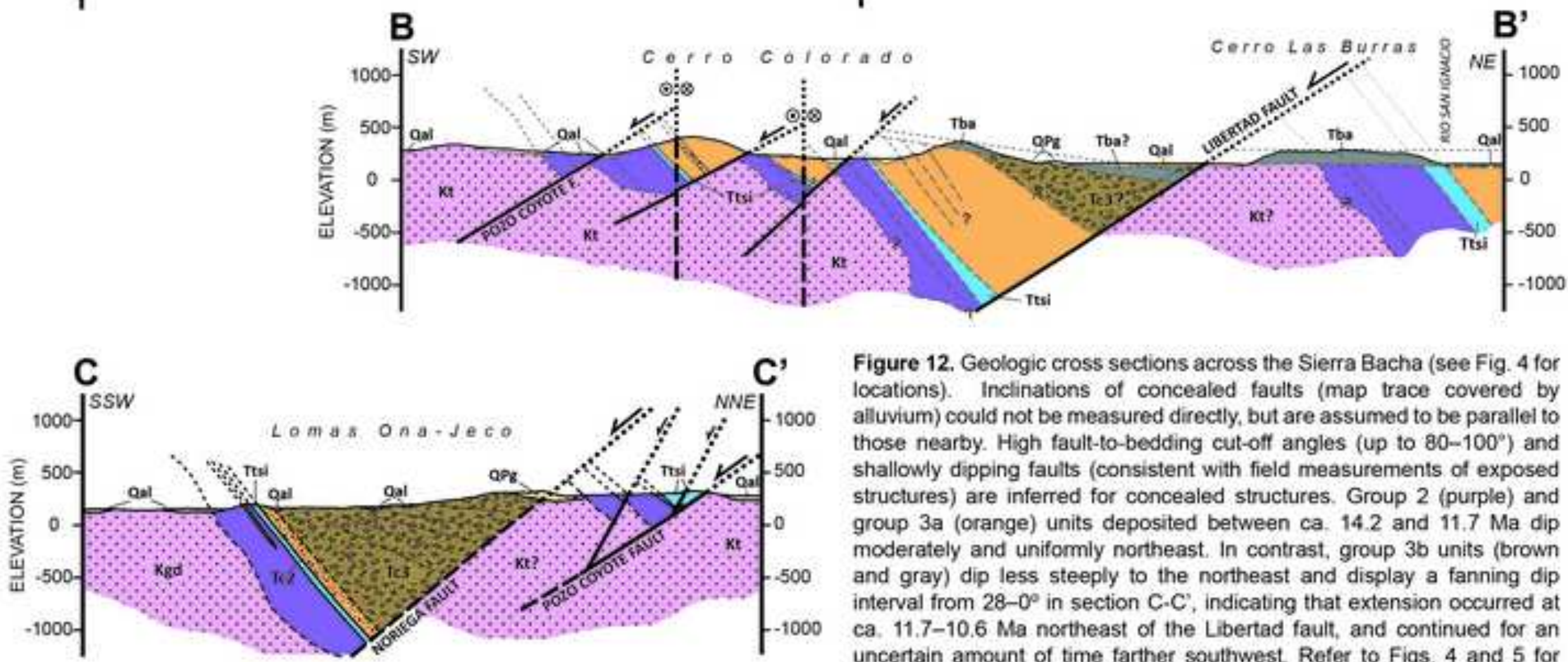

Figure 12. Geologic cross sections across the Sierra Bacha (see Fig. 4 for locations). Inclinations of concealed faults (map trace covered by alluvium) could not be measured directly, but are assumed to be parallel to those nearby. High fault-to-bedding cut-off angles (up to $80-100^{\circ}$ ) and shallowly dipping faults (consistent with field measurements of exposed structures) are inferred for concealed structures. Group 2 (purple) and group 3a (orange) units deposited between ca. 14.2 and $11.7 \mathrm{Ma}$ dip moderately and uniformly northeast. In contrast, group $3 \mathrm{~b}$ units (brown and gray) dip less steeply to the northeast and display a fanning dip interval from $28-0^{\circ}$ in section C.C', indicating that extension occurred at ca. 11.7-10.6 Ma northeast of the Libertad fault, and continued for an uncertain amount of time farther southwest. Refer to Figs. 4 and 5 for legend and an explanation of lithologic groups and abbreviations. 
Figure (with caption below and on the same page)
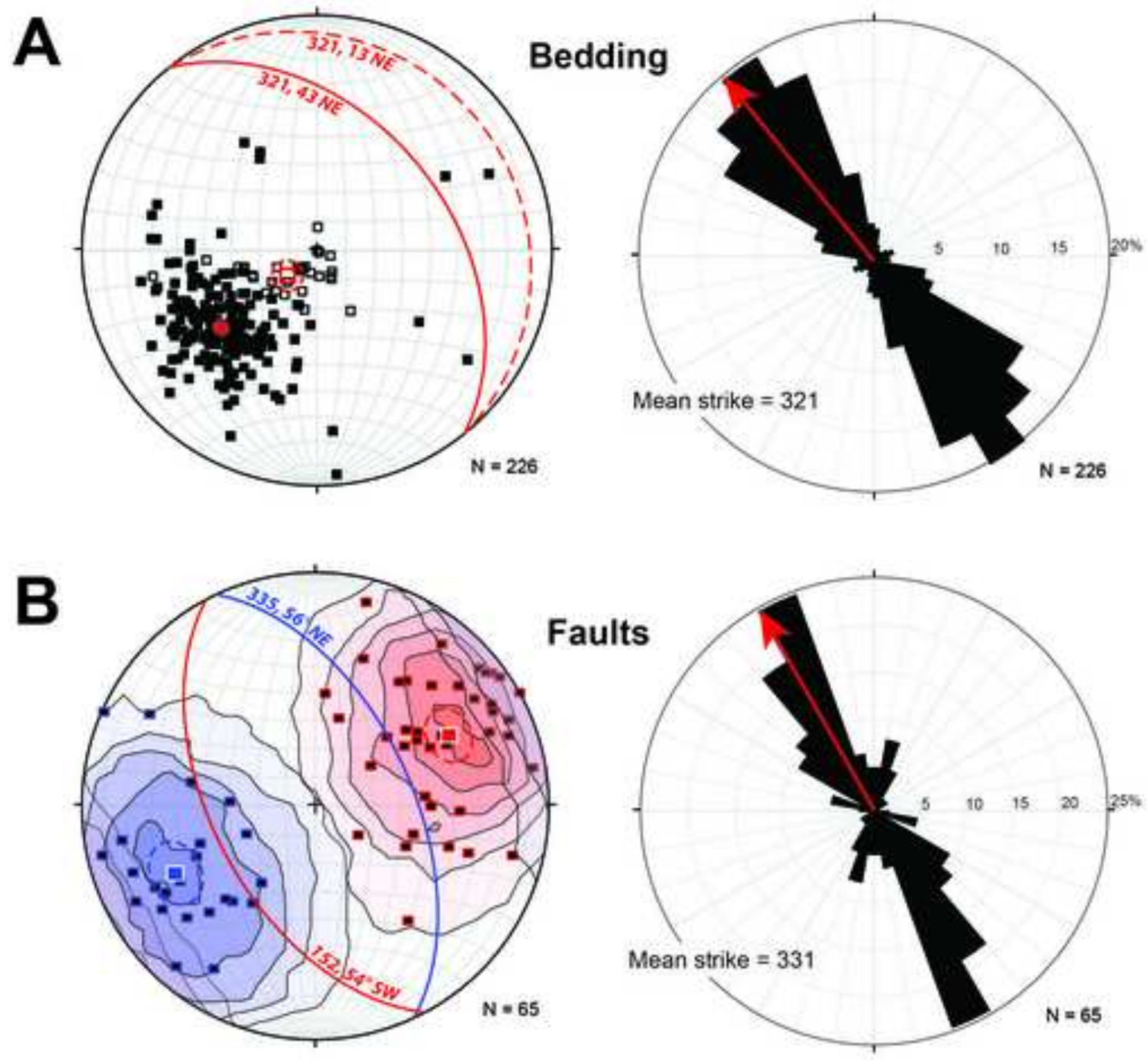

Figure 13. Equal area stereoplots (left) and symmetrical rose diagrams (right) of bedding (A) and fault (B) orientations in the Sierra Bacha. Dashed ellipses in all diagrams are a-95 confidence cone limits for mean vectors (larger squares). (A) Bedding poles from pre-tectonic units (solid squares: $n=196$ ) show an average pole (solid red square) that corresponds to an average bedding dip of $43^{\circ}$ NE (solid red great circle); poles to syn- and post-tectonic units (open squares; $n=30$ ) reveal an average bedding plane (cpen red square) with the same mean strike but a much shallower dip of only $13^{\circ} \mathrm{NE}$ (dashed red great circle), (B) Poles to measured brittle faults (n*65), Kamb contour interval is 20 and significance level is 30 . Faults were differentiated into east-dipping (blue) and westdipping (red) populations and contcured separately due to the bimockal distribution of poles defining a conjugate set of NE- and SWdipping faults. Note that the average strike of all bedding (A) is nearly identical to the average strike of faults $(B)$ shown by red arrows $s$ in the rose diagrams. 


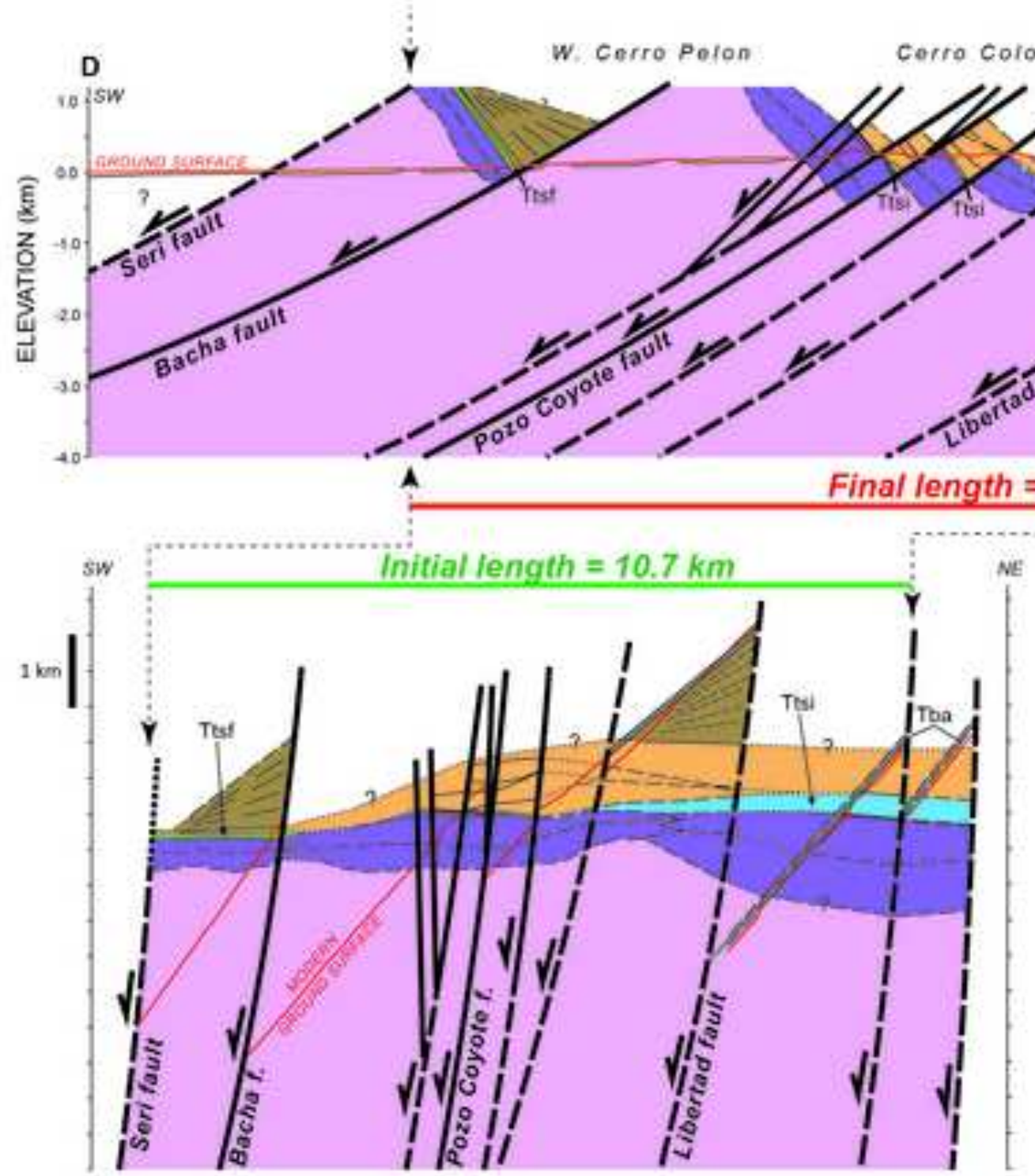

*All sections are drawn to scale (no vertical exaggeration)

Figure 14. Balanced (above) and restored (below) cross section D-D' across the Sierra Bacha; see Fig. 4 for location. This structural restoration, which assumes a single generation of slightly listric domino-style normal faults, reveals $\sim 6.1 \mathrm{~km}(55-60 \%)$ of cumulative NE-SW-directed extension since ca, $11.7 \mathrm{Ma}$ (see text for discussion). Refer to Figs, 4 and 5 for legend and an explanation of lithologic groups and abbreviations. 


\section{Normal faults}
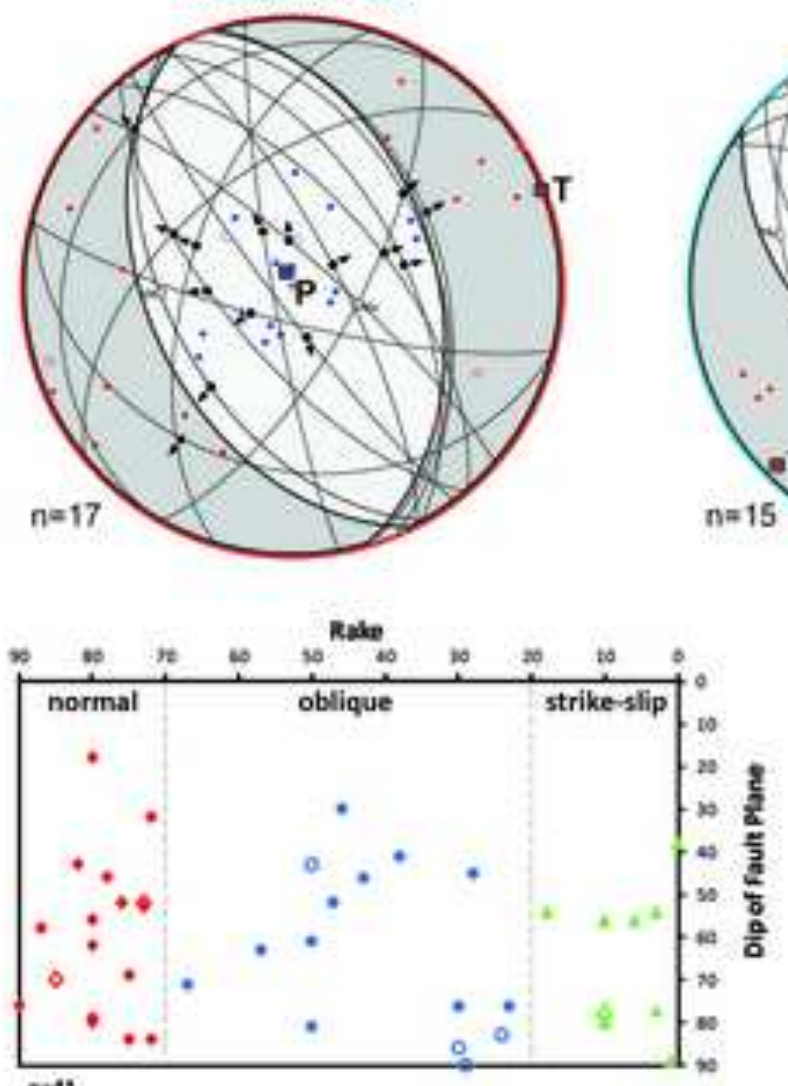

Oblique faults

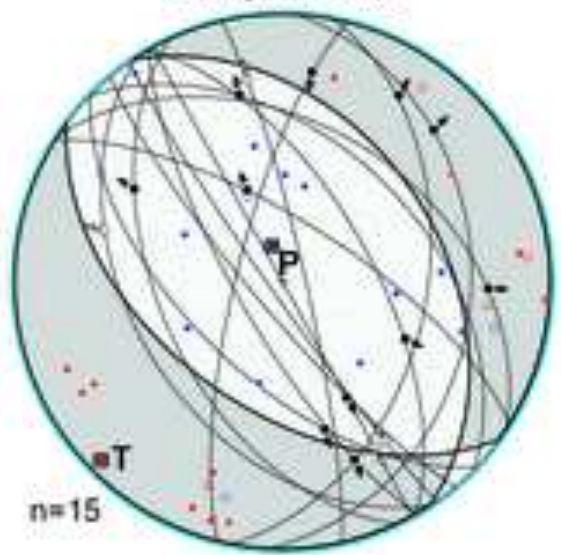

Strike-slip faults

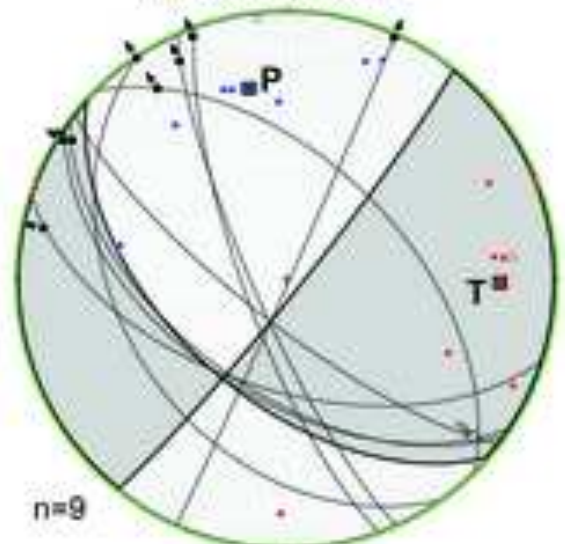

Figure 15. Equal area stereoplots of fault kinematic data and analysis from minor faults in the Siema Bacha Small black dots are slip vectors and small arrows indicate direction of hanging wall movement; $P$-axes (blue dots) and T-axes (red dots) are shown for each fauli datum. Classificalon of fault type is based on the slip vector rake for each fault datum as shown in the plot of fault dip vs rake (center left). Kamb contours of kinematic axes (bottom center) have a contour interval of 20 and a significance level of $3 \sigma$. Fault data with an inferred sense of shear are shown as unfillediopen symbols in all plots (see text for discussion). Intermediate (B) axes (black X's) form a girdle that is broadly coincident with the distribution of P-axes, implying that the $\mathrm{P}$. and B-axns may have been subecual and flipped positions theough time, a relationship that is more consistent with transtension rather than orthogonal extension. The pseudo fault plane solution (bottom right) displays a sub-ventical contractional strain axis (P-axis) and a honizontal mavimum extensional strain axis (T-axis) criented towards azimuth 067 , indicatng that kinematic data are consistent with ENE-WSWdirected extension or dextral transtension duning the late Miccene. Because these minor faults have moderrate to steep inclinations typical of newly initiated fauts (Fig. 128), they likely have not been involved in the titing of fauts and strata by $\sim 40-50^{*}$ across the study area (Fig 12A). Thus, these fault kinematic data are interpreted to reflect transtensional strain after major extension in the Sierra Bacha

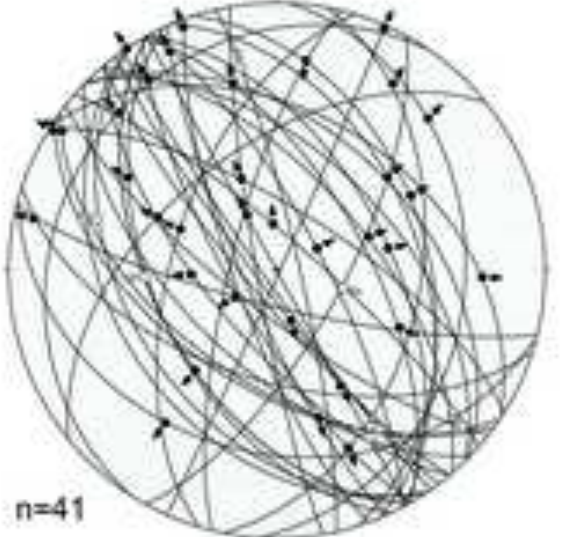

All faults

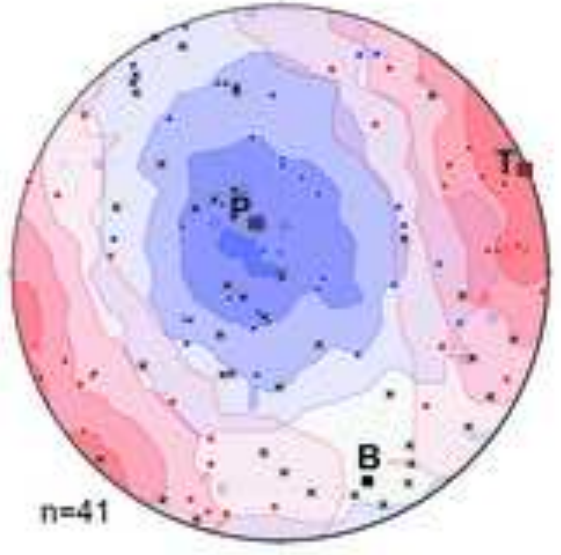

Kinematic Axes

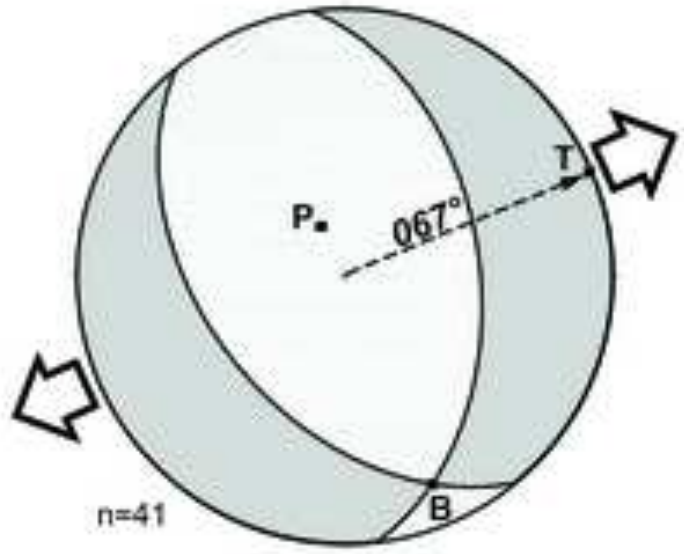

Pseudo-Fault Plane Solution 


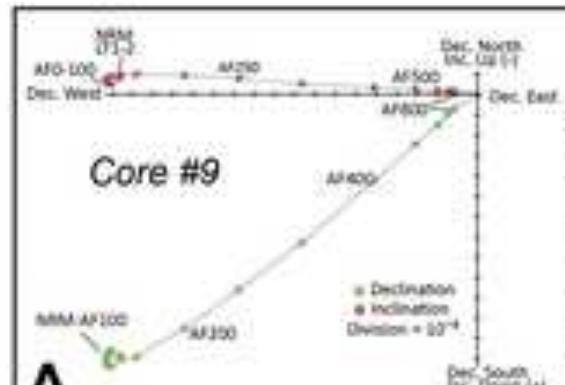

A

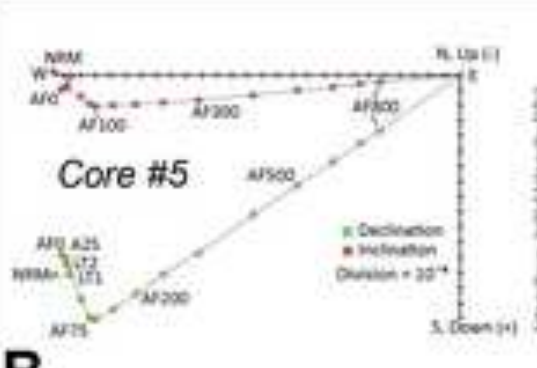

B

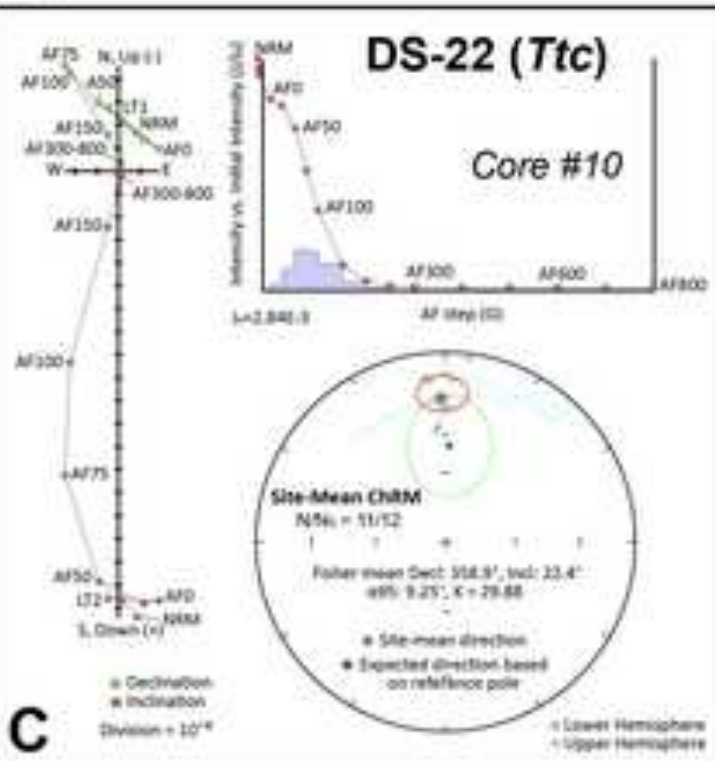

DS-17 (Ttsi)

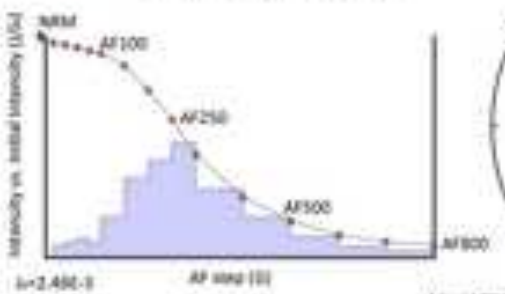

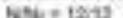

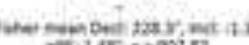

1

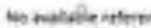

mestinge

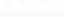

\section{DS-21 (Ttsf)}

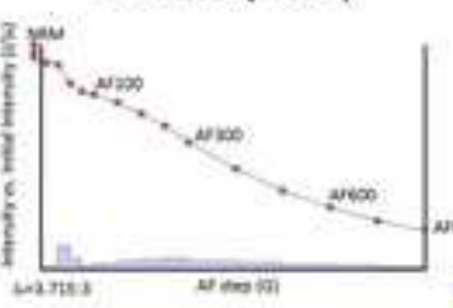

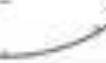

Now 0 tone

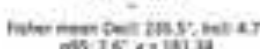

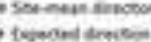

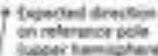

25.
Figure 16, Examples of tilt-corrected paleomagnetic results from the five palecrnagnetic drill sites in the Sierra Bacha (See Figs. 4, 17 for locations), For each site, vector-component Ziderveld diagrams (left) display vector orientations for all natural remanent magnetization (NRM), low-temperature (LT), and alternating feld (AF) partial demagnetization steps (in Gauss units) conducted, Partial demagnetiza. tion steps are shown for only one example core at each paleomagnetic site. J/JO plot is shown for same example core (center in A, B; top-right in C, D, E). Right (A, B) or bottom-right (C-E) plots shows the best-fit lines and the site mean characteristic remnant magnetization (ChRM) vectors calculated using N/NO cores collected. Site mean vectors (yellow star) and $\mathrm{a}$-95 confdence cone (red ellipse) are shown along with the expected remanence vector based on the reference paleopole for each site (green hexagon; green ellipse is a-95 confictence cone). All analyses were conducted with PaleoMag $\checkmark 3.1 \mathrm{~b} 2$ (jones, 2002).

(3)

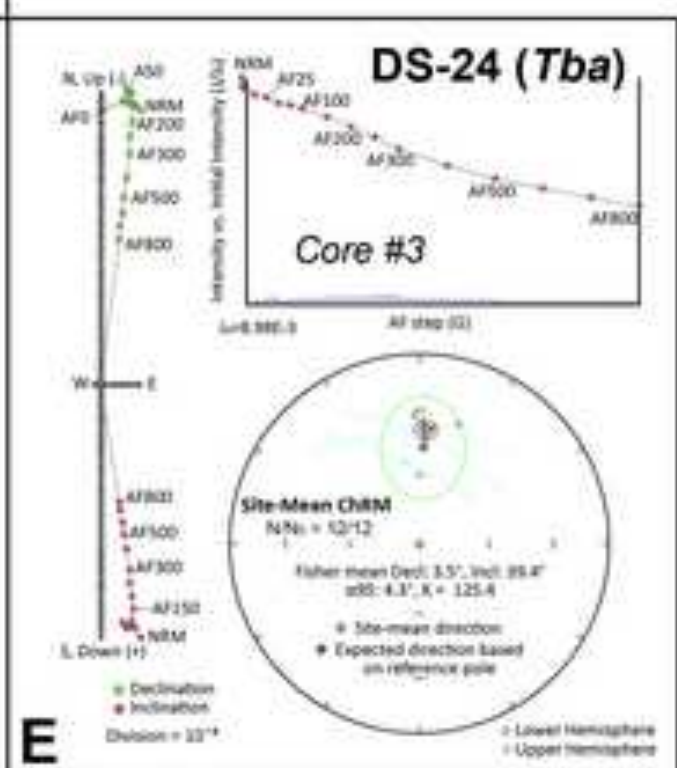




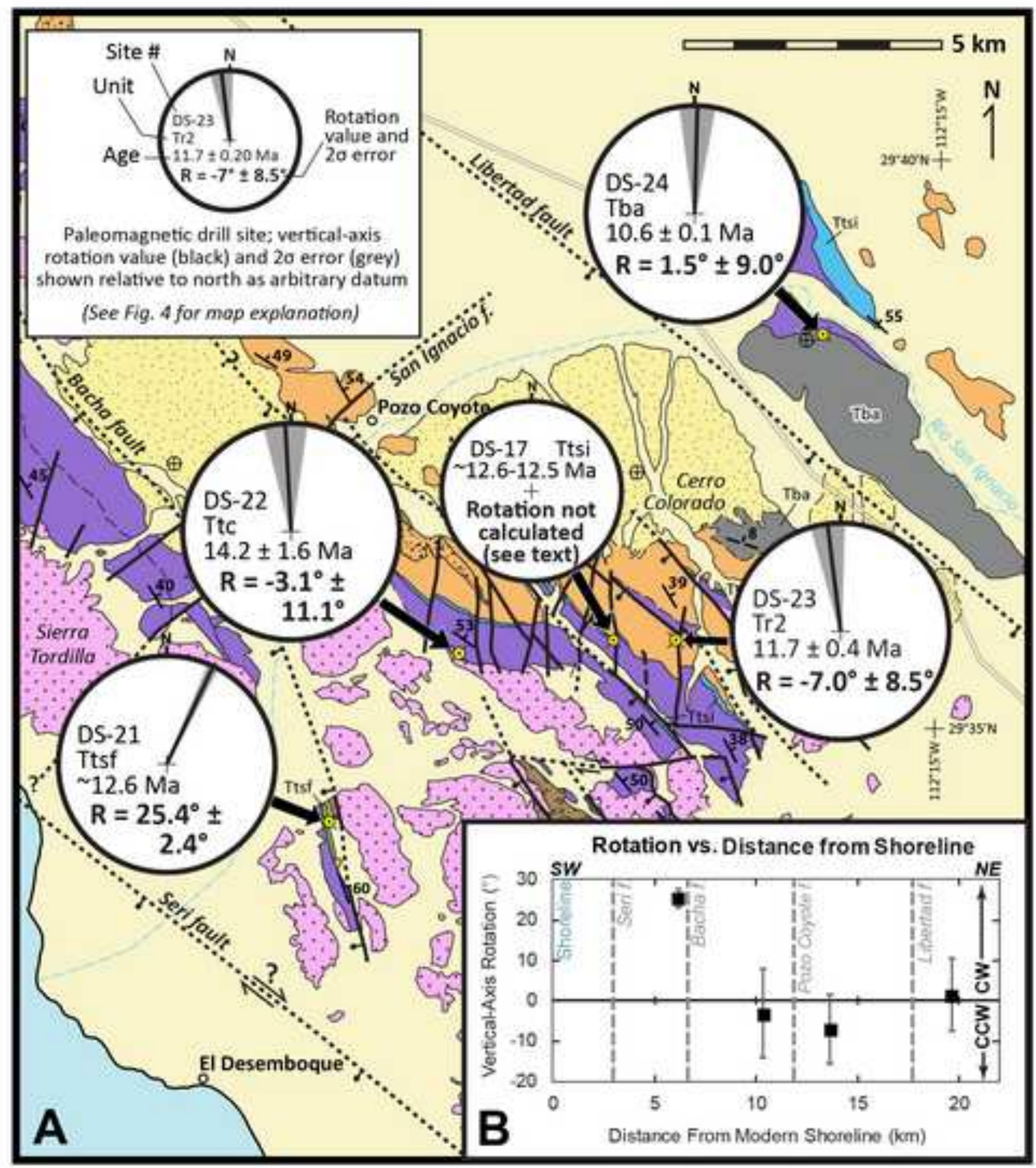

Figure 17. Paleomagnetic data and vertical-axis block rotations calculated for sites in the Sierra Bacha (see Table 3). (A) Paleomagnetic site locations and magnitudes of vertical-axis rotation (see Fig. 4 for explanation of map units and symbols). Rotation cannot be calculated for drill site DS-17 (Ttsi) because the tuff recorded a unique magnetic signature, likely during a field reversal or excursion, and there is no suitable stable reference site for this tuff (see text for discussion). All other sites show unresolvable rotation within standard error limits, except for DS-21 which shows $\sim 25^{\circ}$ of clockwise vertical-axis rotation near El Desemboque in the southwest. (B) Plot of vertical-axis block rotation vs. distance from modern shoreline. These results demonstrate that most of the Sierra Bacha area, especially northeast of the Bacha fault, did not experience significant dextral shear in the form of clockwise block rotations since the middle to late Miocene. $\mathrm{CCW}$ - counter-clockwise; CW - clockwise. 

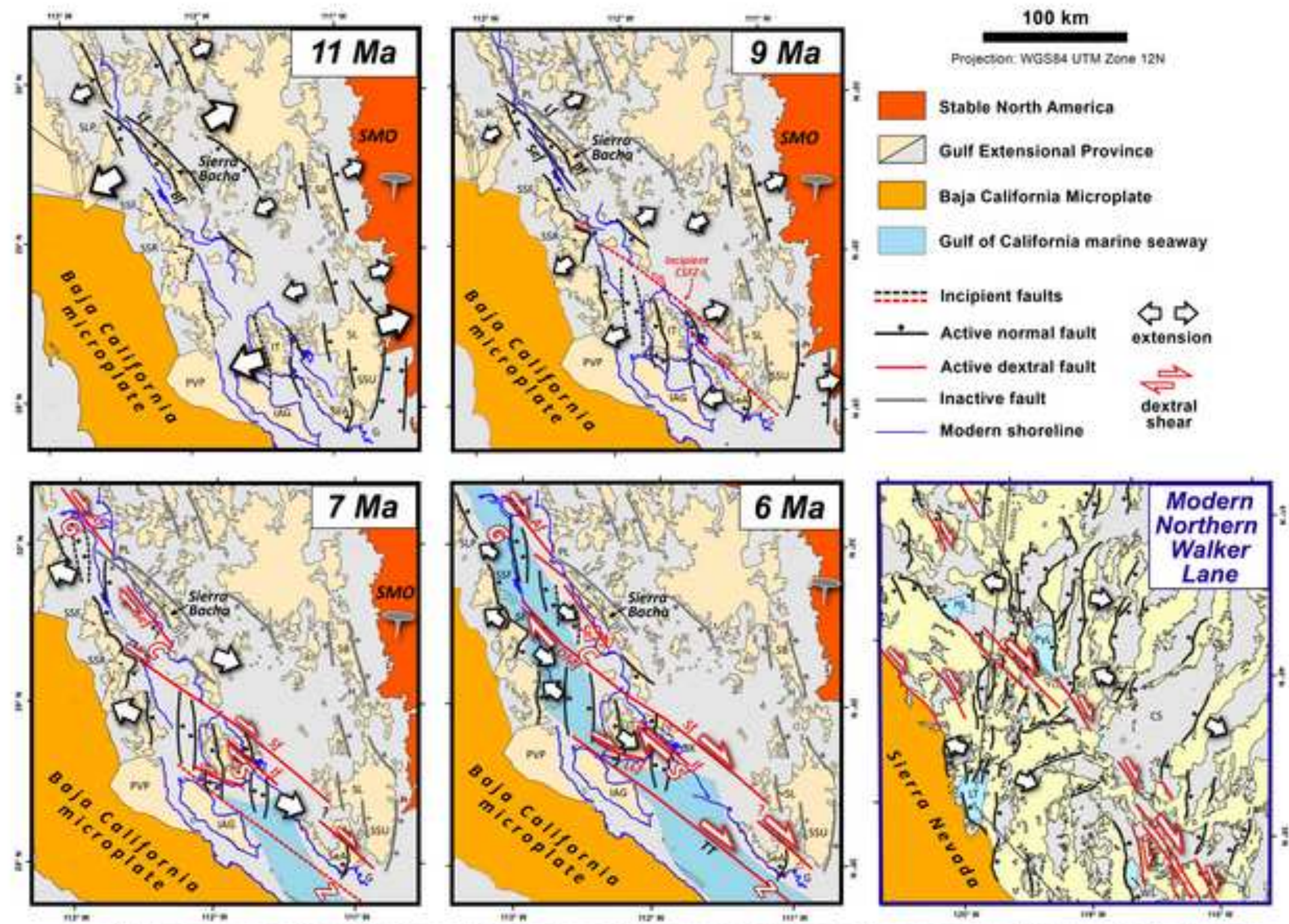

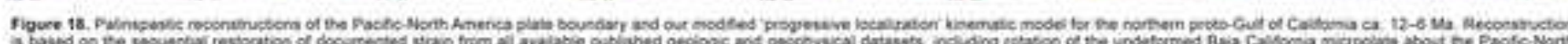

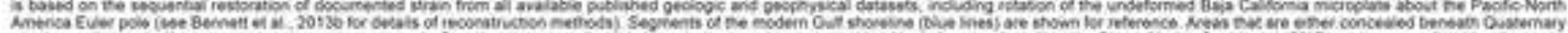

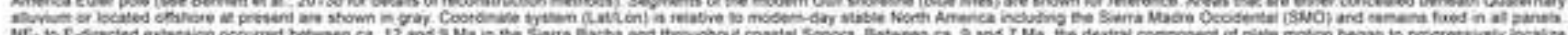

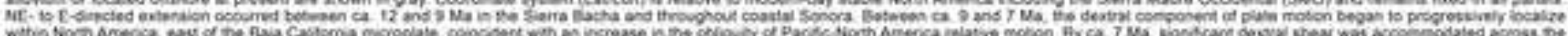

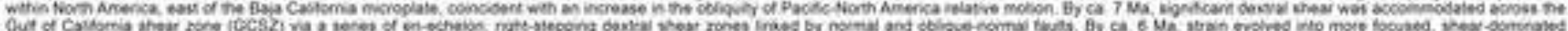

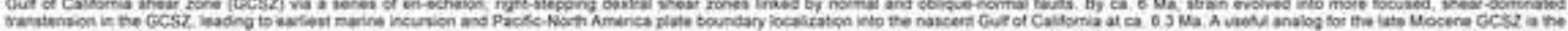

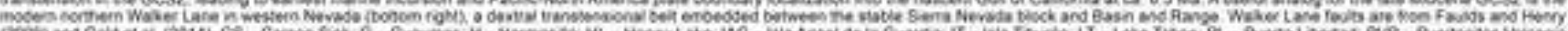

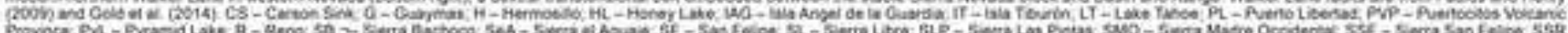

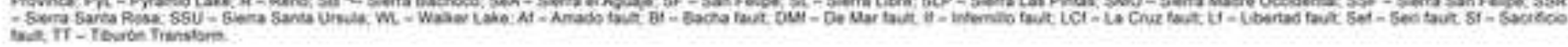

